University of Louisville

ThinkIR: The University of Louisville's Institutional Repository

Electronic Theses and Dissertations

1947

\title{
A distillation study : II. factors affecting plate efficiency : III. properties of laminated wood glue lines.
}

Jack H. Nichols 1922-2007

University of Louisville

Follow this and additional works at: https://ir.library.louisville.edu/etd

Part of the Chemical Engineering Commons

\section{Recommended Citation}

Nichols, Jack H. 1922-2007, "A distillation study : II. factors affecting plate efficiency : III. properties of laminated wood glue lines." (1947). Electronic Theses and Dissertations. Paper 2125.

https://doi.org/10.18297/etd/2125

This Master's Thesis is brought to you for free and open access by ThinkIR: The University of Louisville's Institutional Repository. It has been accepted for inclusion in Electronic Theses and Dissertations by an authorized administrator of ThinkIR: The University of Louisville's Institutional Repository. This title appears here courtesy of the author, who has retained all other copyrights. For more information, please contact thinkir@louisville.edu. 
UNIVERSITY OF LOUISVILLE

I A DISTILLATION STUDY
II PACTORS ATTECTING PLATE BPPIOIENCY
III PROPERTIPS OF LAINATED "OOD GLUE LINES

\author{
A Thesis \\ Submitted to the Faoulty \\ of the Graduate School \\ of the University of Loulsville \\ in Partial Fulfiliment \\ of the Requirements \\ for the Degree of
}

WASTER OF CHOMICAL ENG INERRTNG

Department of Chemical ingineering

Jaok H. N10hols

1947 
This PDF document is a scanned copy of a paper manuscript housed in the University of Louisville (UofL) Libraries. The quality of this reproduction is greatly dependent upon the condition of the original paper copy. Indistinct print and poor quality illustrations are a direct reflection of the quality of materials that are available for scanning. The UofL Libraries greatly appreciates any better copies that can be made available for replacement scans. 
$I$ is DISTILIATION STUDY

II FACTORS AFTZOTING PL TE EFFICIQWCY

III PROPERTIES OF LAIN TED $M O O D$ GLUE LINES

Jack H. Niohols

Approved by the Examining Committee.

\begin{aligned} Direotor G. C. Williams \\ \hline R. C. Ernst \\ \hline W. R. Barnes \\ \hline\end{aligned}

Docember, 1947 
Llst of Tubles.................. v

Llst of Figurea. . . . . . . . . . . . . . 11

Aoknowledgement. . . . . . . . . . . . . vi11

Abatract . . . . . . . . . . . . . . Ix

I. A Digtillation Study

Introduction . . . . . . . . . . . . 1

Historioal ................. 4

Theoretioal. . . . . . . . . . . . 12

Analys is of Problem. . . . . . . . . . 16

A. Equipront . . . . . . . . . 17

B. Prevloug mork............ 80

Experinental ............... 85

A. General Procedure ........... 26

B. Data and Results. .......... 34

c. Correlation and Disoussion....... 51

Summary and conolusions........... 66

II. Factors Affeoting Plate Efflolenoy

Introduotion . . . . . . . . . . . 70

Historioal and Thooretioal .......... 73

Design of Experimental Equipment ....... 100

Disoussion .................... 104

summaxy ................. 107 
TABLS OF CONTENTS - Continued.

Page

III. Properties of Laminated wood Glue LInes

Introduotion . . . . . . . . . . 109

H1storloal ................ 118

Theoretloal. ............... 115

Experimental .......................... 117

A. Struoture of Glue Fllm. . . . . . . 118

B. Penetration of Glue F1Im. ......... 121

C. Resistanoe to 11quid Dierusion. . . . . 126

Summary and conolusions ............. 140

Itterature cited .................. 142 Append $1 x$

Nomenolature. ............. 148

Glossary or Terms. . . . . . . . . . 150

Sample Caloulations. . . . . . . . . 152

Plate Column Construotion. . . . . . . . . 156

Aoknowledgement. . . . . . . . . . . . 159

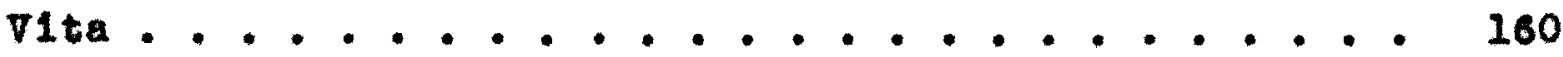




\section{LIST OF TABLES}

Table No.

Page

I. Systems Investigatod ............ 24

II. Analytical Data, Acetone-Water ...... 37

III. Vapor-Ilquid Equilibria, Acetone-Water . . 38

IV, Acotone-Water, Summary Data. . . . . . 40

7. Analytioal Data, Methyl Bthyl Kotone-Water System . . . . . ........... 43

VI. Vapor-Liquia Bquilibria, Methyl Ethyl Ketone-Water .............. 44

VII. Kethyl Bthyl Kotone-Water, Summery Data. . 46

VIII. Analytioal Data, Pentane-Toluene ...... 48

IX. Vapor Liquid Equilibria, Pentane-Toluene . 49

X. Pentane-Toluene, Summary Data. ..... 50

XI. Fuctors affecting Plate Bffloiencles.... 74

XII. Charaoteristios of Planing Specimens . . . 124

XIII. D1frusion Test spoolmens.......... 188

XIV. LIquid Diffusion Trough Laminated Veneers . 137 
Figure No.

1 Effect of Viscosity on Plate Efflolency ..... 9

2 Effeot of Relative Volatility and Visoosity on Plate If flolenoy, Correlation of o'Connell. ...

3 Effeot of Relative Voletility and Viscosity on plate Efflclenoy, Regults of stigger...... ze

4 Erfoot of Refiux Ratio on Overall sfficlenoy in Me thanol-Water Roctifloation......... 23

5 Typloal nata Shoet for Aotone-Water Separation. 30

- Typical Deta Sheot for Uethy1-Ethyl-Ketone-Hater Separation ............... 31

7 Typical Deta Sheot for Pontane-Toluene Separation 32

8 Effeot of Relative Volatility and Visoosity on Plate Efflolency, Acetone-Water System. . . . . 39

- Effoct of Relat1re Volatility and Viscosity on Plate Efflelenoy, MethylSy sten .................... 45

10 Effoot of Relative Volatility and $\nabla 1$ soosity on Plate Efflelenoy, Pentane-Toluene System. . . . 50

11 Erfoot of Relative Volatility and Visoosity on Bf flolenoy, All Data, All Syatema. .......

12 Effect of Relative Volatillty and V1scosity on Roctifler Efflclency, All Deta, All Systems . .

13 Effect of Relative Volatility and Viscosity on Stripper Efflolenoy, ill Data, All Systems. . .

14 Effoot of L1quid Vapor Rat1o on Plato Ifflolenoy, Me thanol-Weter System . . . . . . . . .

15 Effeot of L1quid Vapor Rat1o on P1ate Effiolenoy, Carbon-Tetrachlor1de-Benzene. . . . . . . ?

16 Effeot of IIquid-Vapor Ratio on Stripping Bfflolenoy, Aoetone-Yater System........ 
IIST OF FIGURES - Continued.

FIgure No.

Page

17 Effeot or I1quid-Vapor Ratio on Stripping Efflolenoy, Mothyl Tthyl Ketono-Water System. .

16 Effect of Ilquid-Vapor Ratio on Stripping Efflolonoy, Pentane-Toluene System . . . ... .

19 Effeot of Relative Volatility and Viscosity on Overall column Efflolenoy, All Data, All Systems ...................

20 One Plate, Single slot Rectifler, Number One. . 208

21 One plate, single slot Rectifler, Number Two. . 102

22 Remorablo Plate of Roctifler number Two. .... 102

23 Distribution of Glue N1I In Laminated White Oak venoer................... 122

24 Ilquid Difrusion Apparatus. . . . . . . . 127

25 Acoumulative How of Water In rough Laminated hite Oak Veneer, Specimen No. 5. . . . . . 133

26 Comparison of hooumlative Hows for fll Speolmens ............... 134

27 Rate of How of Water Through Laminated White Oak Veneer, Speolmen No. 5. .......... 135

28 Comparison of Rates of Flow for All Speoimens . . 136

29 Sample Celculation of Theoretloal Plates. . . . 154

30 Detalls of Sxperimental Fractionating Colunn. . 156

31 Detalls of Plate Construction ........ 157

32 General Vlows of Fractionating Column ..... 158 
ACKNOHLZDGMENT

The author wighes to acknowledge

the kind assistance and helpful guldanoe

or Dr. G. C. M1111ans,

who direoted this research. 
ABSTRACT

in extended evaluation of a previousis advanoed correlation is presented with extenglve data obtained from fractionation of a varlety of binary systems in a single column. The oorrelation is shown to bo capable of predicting plute erficiencles well within the linits of mechanioal design over wide ranges of relative volat1lity and viscosity.

is survey of the 11terature concerning the extent to whloh various factors affect fraotionation plate officienoles is presented. Equipment is designed and methods suggested for correlation which may be evolved from existing data and from future experimental data.

The results are presented for an investigation of the physioal properties and charaoteristios of laminated white oak glue fllms. Some data are included whloh show the resistance of Penacolite o-1124 glue flims to 11quid diffusion and suggestions are inoluded for correlations on the basis of fabrioation and curing conditions. 
I A DISTILLATION STUDY

\section{INTRODUCTION}


The use of diatillation as separational

process for refinement of materials has been one of the most important operations praoticed by manufacturing industries. The prinoiples of distillation, 1. 0 thermal separation by differential volatilization, are incorporated in each of its many forms.

One of the most used forms of distillation is that known as plate fractionation. A factor of importance in the design of plate-fractionating column is the determination of the number of plates required in the column. Theoretleal relationships ovolved by numerous investigators $(1,2,3,4)$ have suggested caloulations for the number of plates necessary to produce a spectfled degree of separation of components. These methods, however, produce a result based on the premise that a complete and unitized interohange of components takes place on the plates. Since this ldeal situation does not exlst, the resulting "theoretioal number of plates" must be modified to predlot the actual number of plates required for a given operation. The design for plate-fractionsting columng includes the determination of the type, 81ze, and spacing of plates, placement and nature of welrs, oriflces, heating colls, to. which will give optimum rosults with the least expenditure. The determination of the relation between actual number of plates required and the theoretioal number of plates has, however, been a factor of great concern to desleners. 
At temptg have been made to correlate the theoretical calculations with the results obtained in the field, and these have produced a ractor known as the plate erfiolency. Th1s factor for many distillation systems may be found in the 11terature, as obtained under speciflo cond1tions, but the references are too meager for the expanding field of distillation design. There have been many attempts to correlete this plate efflclency faotor with the many variables whlch might affect its magnitude. These correlat1ons have resulted in only a few procedures which give promise of reasonable accuraoy.

Realizing the Inadequacies of these attempts at correlation, o'Connell (5) expanded the work of other Investigators to show a correlation of an overall plate eff1olency in fractionating oolums as a funotion of the relative volatility and visoosity of the key components. Using o'Connell's work as a basia, stigger (6) produced a partial eraluation of this correlation based on experimental data obtained on aingle colume.

Th1s paper presents the results of a continuation and expansion of the reseuroh profect inftiated by stigger and reported in his "Correlation of Plate Effiolenoles in Tractionating columns", (6). 
HISTOR ICAI 
One of the oldest technical preotices in existence Is that of distillation. Th1s fleld has been alopted by chemical engineers and incorportated in their philosophy as one of the unit operations of chenicul enginearing. For many years there was no real engineering design of fractionation equipment. Results of the first worthwhile attempt to rationalize oolumn lesign were presented by sorel (4) at the end of the nimeteenth century. sorel worked from equilIbriun relationahips between 11 quid and vapor mixtures. If It had been possible to obtain vapor-11quid equilibrium In a colum, Sorel would have solved the question of column design from the standpolnt of the number of plates required for a given separation. In praotioally every case, however, the etteinment of equilibrium $1 \mathrm{~s}$ lmpossible, and a fleld was opened for investigator to find a definite basis for the aifference between the theoretioal and the aotual number of neoessary plates.

The discrepanoy between actual and theoretioal plates, termed effiolenoy, required a mathematioal description. Thlo expression took three ceneral forms: (1) point efrlolenoy. (2) Murphree plate efflolenoy, and (3) overall effletency.

Point effleienoy 1 described as the efricienoy at one point on any plate in a colum, and $1 \mathrm{~s}$ the rat 10 of the enrlohment obtained to the enrlohment under equilibrium conditions at the designatod point.

Murphree plate efflolonoy is essentially the 
same as point effiolency except that the enrichment is based on the average composition of vapor entering and that leaving a plate, in comparison to the average liquid leaving the plate.

Orerall efflcienoy is the ratio of the theoretioal number of plates to the actual number of plates required for a given separation.

For engineering oalculations overall efflolency values are the easlest to use, the most consistent, and in most cases the least diffloult to obtaln.

Barly workers, noting that different columns gave different operating charscteristics for similar materials, made an effort to relate the column efflciency to mechanloal dezign aspects of the column.

Peavy and Baker (7) investigated the effeot of vapor velocity on plate erficlenoy, and reported that plate offlofency increases with increasing velocity, becoming fainy constant over a considerable range at moderate velocities. At hlgh velocities, efficienoy drops as a result of entrainment and liquid carry-over to the next plate. In order to deteralne the opt Imum velooity on the basis of maximum officlency, a method was developed by Brown and souders (B) and expanded by Brown and Lockhart (9). Carey ot all (10) determined the effect of slot submergence and slot velocity on plate efflclency. They concluded that the efriclency increased as slot submergence increased; and, for normal operating velocitles, 
the effiolency was essentlally independent of slot velocity.

In order to insure stable plate operation, the

11quid load must be maintained below the value which would produce a greater 11çuld hoad at the entranoe to the plate than at the overflow from the plate. Allowable liquid loads are predictable acoording to the mothod discussed by Good ot al (11).

O'Connell (5) has stated that the dameter of the column does not affect plate efflolenoy if diameters are loss than flve feet. However, if columns are lareer than seven feet, the length of the Ilquid peth(oross flow effect) must be taken into acoount.

The effect of mechanical design factors on plate efflolenoy has beon confirmed in practice. Yet, when a column is deslgned for optimum efflolency, based on these mechanical factors, a considerable divergence of results may be obtalned when the column is operated with different systems. Th1s varlation auggested the possibility that physical properties of the process meterlals might affect the efficiency of the separation.

One of the flrst physloal propertios investigsted with regard to its offeot on plate effloloncy was viscosity. Walter and sherwood (12) have shown that in the absorption of various meterials the absorption efficienoy increased with decreaeine v1soosity of the absorbant. Moreover, Keyes and Byman (13) presented evidence of viscosity 
affooting plate efficienoy in laboratory distillation of othanol-water mixtures.

If visoosity affoota absorption efflolenoy, as has been shown by ralter and sherwood, then it follows that there should be a similar erroot in rractionation, since both operations are diffusional processes. This conclusion 1s based on the postulation that the major portion of the enrichment during fractionation, is a result or selective counter-diffusion of the key components in the froth above the plate (5).

Wost of the work on viscosity involved the use of Iaboratory data and was thereby IImited as to commerciul applioation. Jrlckamer and Bradford (14) published a derinite oorrelation of plate efflolener as a funotion of viscosity (Figure 1) wherein the erflolenoy was shown to increase with decreasing viscosity. The data for this graph were obtained from commerolal operations, of systems of hydrooarbons having low relative volatility between the ker oomponents.

Gerster, Koffolt, and Withrow (15) presented - vidence that the aotual number of plates required for a given separation was a runction of the slope of the -quilibrium ourve. From this, and the previous ilterature 0'Connell (5) deduoed that the linttations of the correlation of Drlokamer and Bradford could be reduced by correlating plate efflolenoy as funotion of the viscosity and 


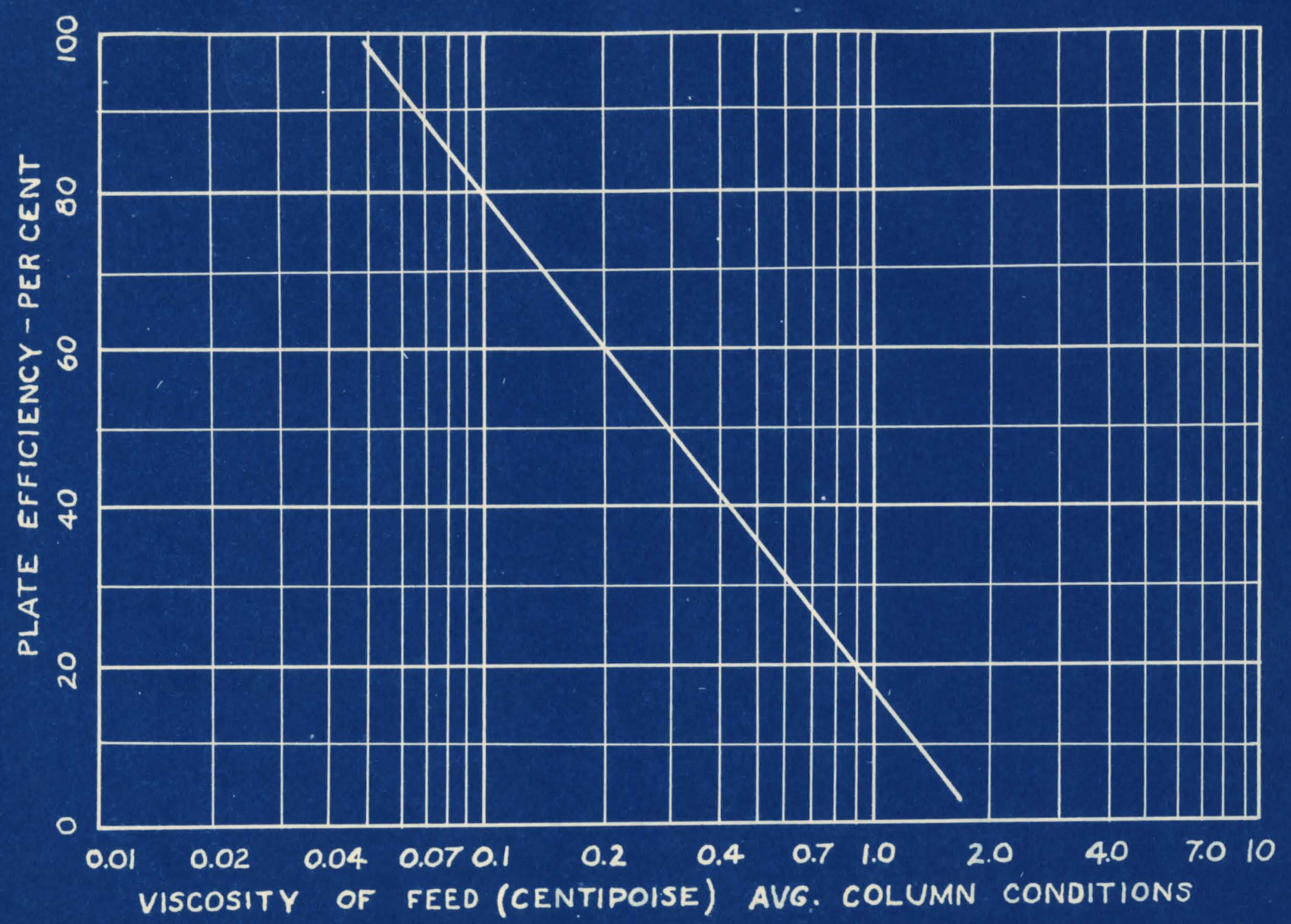

FIG. I - EFFECT OF VISCOSITY ON PLATE EFFICIENCY (CORRELATION OF DRICKAMER AND BRADFORD)(G) 
the relative volatility of the key oomponents.

His correlation (Figure 2) alvanoes the relationahlp as a simple plate efflolency vo. viscosity-relative volatility product and was estimated from the results of actuel experiments with numerous hydrooarbon, and non-hydroorirbon systems.

This correlation was presented as non-specifio function, but was not fitted with equations. It was considered to be well within the 11mitations of normal column oloulations, and hes been gubstantlated by some results from commerolal units subsequent to its presentation. stleger (6) presented evidence to support o'Connel1"s oorrelation in the form of data which were obtained from rectifloation of binary mixtures. He used a single colum in his work and thus ellminated the effects of variation in mechanicel design. His Investigation included the separation of five binary mixtures of widely variant properties. Stiger's data supported the correlation of o'connel1 in reotification work in certain ranges. This work was used as a basis for the extended evaluation presented later in this report. 


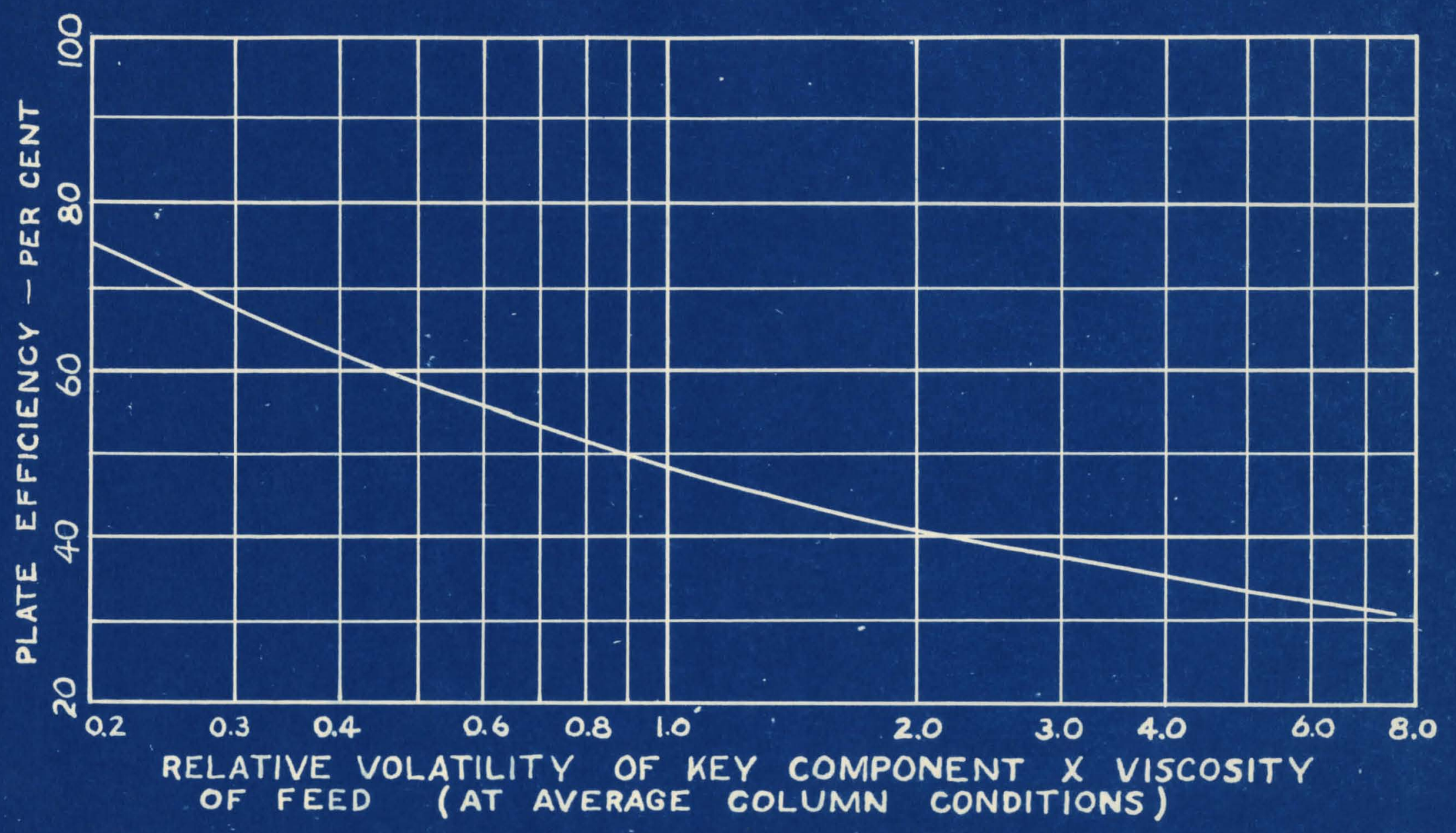

FIG. 2 - EFFECT OF RELATIVE VOLATILITY AND VISCOSITY ON PLATE EFFICIENCY

(CORRELATION OF O'CONNELL) (6) 
THEORETCAL 
EFFTCT OF VISCOSITY ON PLATE EFICIBNCY

The theoretioal bookground for the effoct of viscosity on plate efficlenoy was summarized by Stigger as follows $(6)$.

First, the Stokes-Einstein equation for diffusivity,

$$
k=\frac{R T}{6 \pi N \mu r}
$$

pregents diffusivity, $k$, as an inverse function of viscosity, $\mu$.

where $k=$ diffusivity, square feet per hour

$R=$ Dniversal gas congtant

$\mathrm{T}=$ Temperature, degrees Kelvin

$N=$ number of mols transferred

$\mu=\nabla 18001 \mathrm{ty}$

The equation for mass trensfer developed

by Ch1lton and Colburn (16) Indloates that mass transfer, the ooefficlent "Is", under turbulent conditions

is an inverse function of visoosity, $\mu$.

$$
\mathrm{K}=\left(\frac{a \rho}{\mu}\right)\left(\frac{\mathrm{k}}{\mu}\right)^{0.67}
$$

where $K=$ mass transfer coefficient

$$
\begin{aligned}
& G=\text { Mass velooity of gas } \\
& M=\text { mean moleoular welght } \\
& \rho=\text { density }
\end{aligned}
$$


Purther evidenoe was presented by von Karman (17) in his equation for f1lm thiokness;

$$
s=\frac{(\text { constant })(\mu)}{(0) \frac{t}{2}}
$$

where $\quad z=f i l m$ thickness

$I=$ fanning friction factor.

Fere the fllm thlokneas, $s$, is shown to be a direct funotion of the riscosity, $\mu$.

Sherwood and alter (12) developed an equation

for 11quid mass transfer,

$$
\mathrm{K}_{\mathrm{I}} \mathrm{a}=\frac{3.4}{\mu)^{0.58}}
$$

where $\quad \mathrm{K}_{\mathrm{I}}=$ the product of the mass transfer coefflclent and the wetted area, used as a unt.

Fere there is an inverse relationsh1p between the I1quid mass transfer coefflolent, $K_{L}$ and viscosity, $\mu$.

Although none of these equations indicates a constant mathematioal relationship between viscosity and plate efflolency, they all show that viscosity enters into the value of numerous factors whloh do affeot the degree of separation attainable through eractionation.

MFESCT OF RELATIVE VOL TIIITY ON PLATE BFICIENCY

In the work of Gerster, Kofolt and 1throw (15) It was pointed out that the slope of the equilibrium ourve 
had a direct bearing on the actual number of plates required per transfer unit. If the number of transfer units 1s equal to, or has a direot relation to, the number of theoretioal plates required, then the plate officiency may also be considered a funotion of the slope of the equilibrium curve. If the relative volatility is a funotion of the slope of the equilibrium curve, or, more procisely, a mathematical representation of the slope, then it follows that there should be a connection between plate efflelency and relative rolatility.

Al though no theoretioal explanation for the relationship is avallable, 0 Connell (5) presents the following in support of such conclusion:

"The effect of the relative volatility was shoun by the results of a test on an ethylene dichloride stablilzer. In this oolumn, the feed contained both water and ethyl chlorlde whloh had to be reduced to low concentrations in the thylene alohloride bottoms. The plate efflciency based on water as the low bolling key component (ethylene dichloride the hlgh bolling key) was $29 \%$ and the relutive volatility between water and ethylene alchlorf de was 16 . The plate effiolency based on thyl ohloride as the low bolling key component was 57\%, and the reletive volatility between ethyl chloride and ethylene dichloride was 3.1."

A product of viscosity and relative rolktility cen have no physioal signirlcance, nor can this product be justifled on strietly theoretloal 11nes. However the prevlous references do indioate some such runotion which for brevity and ease is presented in this form. 
ANALYSIS OF PROBLAN 
EQUIMUNT

As proviously stated it was desired in this project to evaluate a predetermined relationship between the plate efriolenoy of alstillation system and the viscosity-relative volatility product of the same system. Plate offlolencles have been shown to vary with different columns, Airforent now rates and other mechanical factors $(7,8,9,10)$. If the correlation is to hold in general, It should hold even more rigldiy for a single column operated under derinite and specirie conditions. It was proposed to utilize one column for this Investigation, using different systems, but with as closely constant operating conditions as possible.

It was desirable that the column correspond as closely as possible to commerotal size and operation. The unit chosen for the work was a copper laboratory experimental oolum with the following specifications (18).

Number of pletes 20 (plus reboller)

Diameter

10 Inches

Plate spacing

8 Inches

Vapor risers

1-5/8 Inch dia. (4 per plate)

Downoomers

1nch dia. ( 2 per plate)

We1rs

6 Inoh $X 1$ in. (2 per plato)

Bubble oaps

2를 in. dia. $x 1-3 / 4$ in. high

(4 per plate)

Slots

5/8 in. $\times 1 / 8$ in. (31 per cap) 
Calandrla (Raboller)

Feed arrangement

Feed pot

Overheads

Sampl1ng

Temperatures
12 in. d1a. $X 12$ in. Iong (shell)

241 in, tubes with auxillary

open steam conneotion

Liquid feed inlets on plates 1, 3, 5, -... 15, 17 (from top)

vapor feed inlets on plates 2, 4, $6, \ldots . . .18,20$ (from top)

liquid feed delivered by gear pump through a rotameter

60 gallon oupacity

Two condensers (tube and shell)

splitter box arranged to produce any desired portion or overheads as reflux to top plate product and reflux flow by gravity through rotameters sample cooks arranged to produce samples of the liquid off plates $1,3,5, \ldots-17,19$

Samples of feod, wasto, and overheads easily obtainable Plate temperatures obtained by copper-oonstantan thermocouples In the Ilquid on plates I through 20

The column was designed for a maximum feed rate 
of twenty gallons per hour, and for satigfactory operation on the systems, ethanol-water, benzene-toluene, and acet10 aold-water at vapor veloolties between 0.75 and 1.85 feet per seoond. (A sketch of the column and detalls of plate construotion are shown in Figures 30 and 31 , Appendix.) 
PREVIOUS WORK

The data used by orconnell in the original placement of $\mathrm{hls}$ oorrelation foll ithin the limits of $27 \%$ and $90 \%$ plate effloiency and 0.10 and 7.5 viscosity-relative volat1lity product expressed in terms of centipoises. It was desired that this investigation extend the range of the vigoosity-volat1lity product to as low and as high a value as pogsible, while at the same time covering intermediate points with a variety of systems.

Mathematioally the game product of $\nabla 1800 \mathrm{ity}$ and rolatility may be obtained by an Increase of one value if the other decreases oorrespondingly. This lent 4 further degree of variunce in the cholee of systems.

Examination of the 11terature for binary syatems with variety of noleouler structures, viscosities, volat111tles, and known vapor-11quid diagrams, alsolosed approximately two dozen systems falling within the permissIble temperature and pressure range of the apparatus. of these systems many were disoarded because of hazardous operation, similar nature, Inability to obtain easy and acourate analysis, or presence of abnomalities in the - quilibria.

The systems chosen and investigated by StIgger (6) are as follows: 
Sygtem

Ethanol -water

Methanol-Water

Benzene-Toluene

Benzene-Carbon Tetrachloride

Acetaldehyde-Hater $\frac{\text { Range of } \mu \alpha, \text { (centipolse) }}{1.0-2.0}$

$1.0-2.5$

$0.69-0.78$

$0.38-0.44$

$5.0-50$

Average results of the work of stigger are shown In flgure 3. The ge data cover a falriy wide range of the oorrelation in question and are represented oomparatively wall by 1t. Figure 3, however, indioates that the correlation 1s not applioable for the atripping efflolenoles as presented. In an attempt to partially explain the nonapplicablilty of the correlation for stripper operations St1gger presented the data for the gystem methanol-water as anotion of the reflux ratio as is shown in figure 4. Th1s curve indioates a relation between the plate efficienoy and the reflux ratio in reotifying sections, where the rerlux ratio is below one. In stripping sections, however, the ratio of 11 quid to vapor is greater than one. If the relation of Ifure 4 can be extended to inolude stripping seotions then an explanation for high efflolenoles in tripping operetions w111 have been found.

To complete the evaluation of the correlation of o'connell it was declded to inolude the study of three additional systems whioh would 1111 in the ranges not oovered previously and at the same time would extend the correlation to a high value of the visoosity relative volatility product. The systems chosen are shown in Table I. 


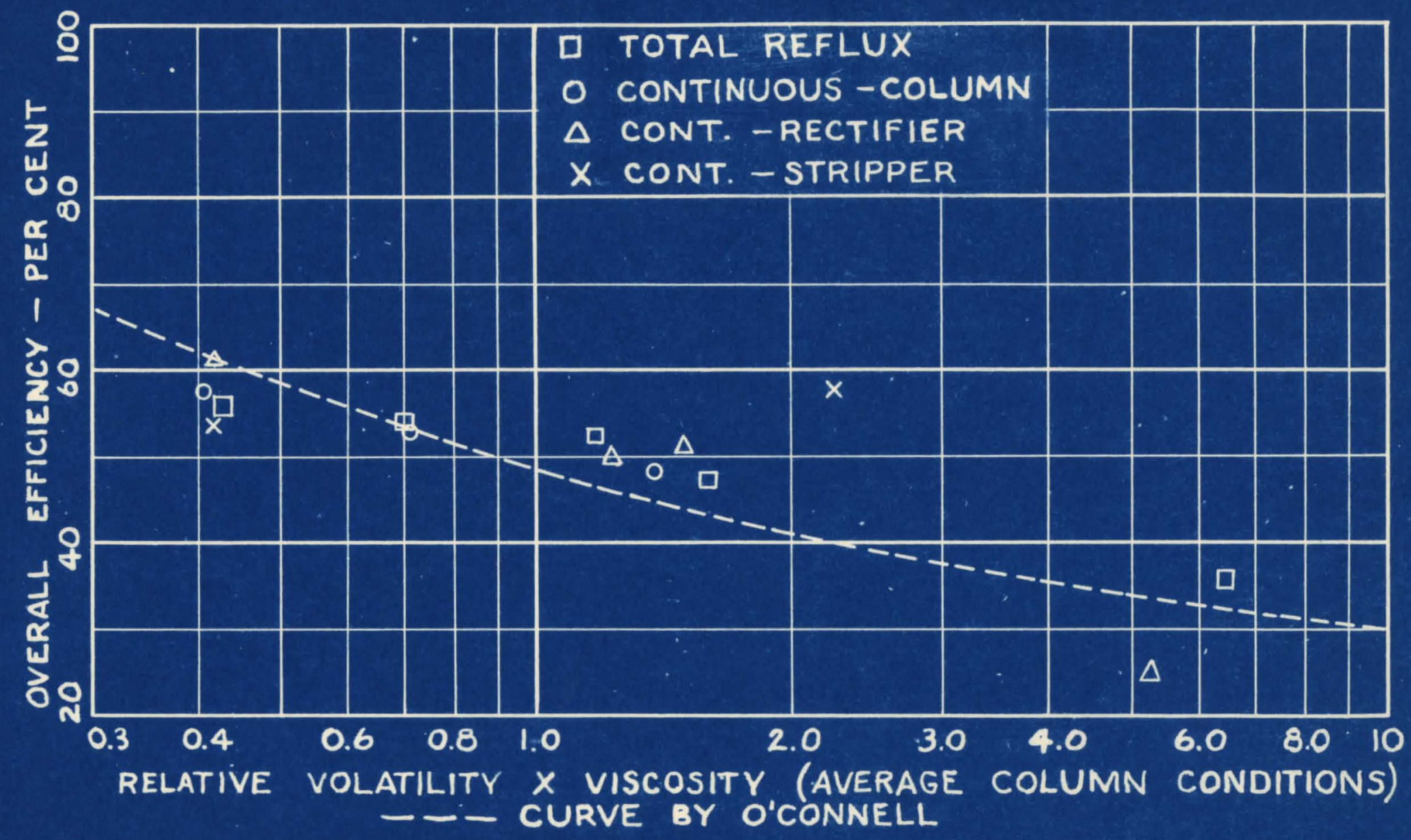

FIG. :- EFFECT OF RELATIVE VOLATILITY AND VISCOSITY ON OVERALL EFFICIENCY

(AVERAGE RESULTS BY SYSTEMS.)(G) 


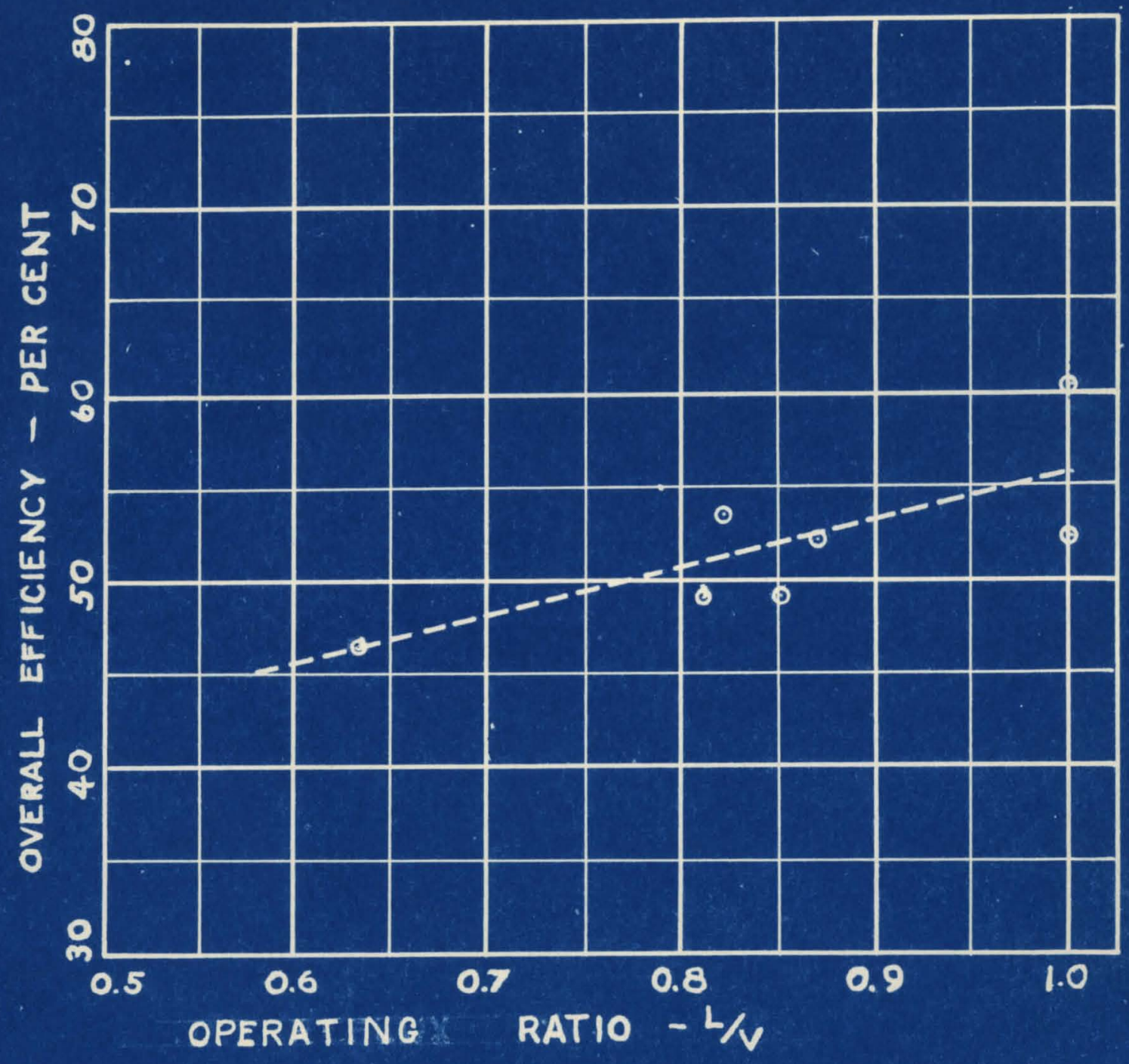

FIG. 4 -EFFECT OF REFLUX RATIO ON OVERALL EFFICIENCY OF RECTIFYING SECTION (6) SYSTEM : METHANOL - WATER 
TABLE I, SYSTHAS INVESTIQHTED

Ho. System

1 Aootone-water

2 MFK-water

3 Pentane-water
Bolling point range

$$
58.1-100^{\circ} \mathrm{C}
$$$$
73.8-100^{\circ} \mathrm{C}
$$$$
36.7-110.7^{\circ} \mathrm{C}
$$

Centipoises

$0.4-9.0$

$10-80$

$1.5-2.5$ 
EXPERIMINTL 
GENERAL EXPERINENTAI PROCRDURE

A general outline of experimentel proeedure which was sufflolently Plexible to accomodate the different systems and various conditions of operations to be enoountered was developed for this investigation. This general procodure was used as a basis for four types or operations:

1. Total reflux operations.

2. Oontinuous overall colum operation, with feed near the center of the oolumn and both rectiflation and atripplng data being obtained.

3. Continuous fractionation with the greater part of the column under stripping conditions, and feed near the top of the oolum. Inls type of operation gave data on the characteristics of the system being studied under stripping conditions.

4. Continuous ergotionation, w1th the greater part of the column ecting as a rectifier and foed near the bottom of the column. Data obtalned from this type of run for the most part oovered reotiflcation characteristica.

In preparation for a total reflux mu, approx1mately fifty gallons of material were placed in the atill feod tank. A quantity of the mixture was placed in the reboller of the still so that the steam heating tubes were covered. cooling water was turned into the condensers and steam was adnitted to the reboller. Partial distribution of components was attalned as vapors rose in the column, 
heating the entire column to operating temperature. As the vapor rose in the column and the liquid level in the rebollor fell, aditional feed mixture was pumped into the column. The flow of feed was manualiy controlled to maintain the deelred level in the reboller, unt1l condensed vapors reentered the top of the column as total reflux. The foed was shut off and the column allowed to operate at totel reflux until equilibrium oonditions were approached.

The approuch of the column conditions to those of equilibrium was observed by taking thermo-couple plate temperature readings at frequent intervals. wen these readings became constant, It was assumed that the column had reached equilibrium. If, on total reflux runs, it was desired to adJust the range of component distribution, the change was made by the addition of foed and the removal of elther distillate or waste.

The temperature of the llquid on each plate was recorded, later to be averaged for determining viscosity and relative volatility values in the column. Samples were withdrawn from alternate plates $(1,3,5--17,19)$, from the distllate, and from the reboller. These samples were usually about $25-30 \mathrm{ml}$. In volume and were obtalned in the shortest possible time so that the equilibrium conditlons of the colunn would not be adversely affected. The quantity of distillate could be observed at any time during operstion by readings on tapered-tube reflux rotameter. 
Temperature measurements were made with copperconstantan themocouples inserted in the 11quid olose to the center of each plate. The readings were direot with the use of a Leeds \& Northrop automatioally compensating potentLometer.

Continuous column operations were started in the sane nethod as that for total rerlux mus. At the point where total reflux oonditions would have been attained, contInuous feed was introduced at a motered rate onto the plate oontalning a mixture most nearly corresponding to the concentration of the reed. The distillate was continuously split into produot and reflux with the product rate adfusted to remove the proper amount of low boller frow the system at this point and at the same time to produce the desired reflux ratio.

Two method were used to effect a change in reelux ratio:

(1) Feed and product rates were held oonstant while the heat input to the reboller was ohanged.

(2) Heat input to the reboller was held congtant whllo the feed and/or produot rates were ohanged. In each case the regult was a ght in the component distribution and this necessitated a corresponding period for colum roadjustment.

The bottoms rate was adusted to maintain a constant 11quid level in the reboller. Continuous reed, 
product, and bottoms rates were carefuliy controlled for a period sufficiont to produoe steady operation as indioated by constant plate temperatures. Samples and data were obtalned as during total reflux, with the adition of a feed sample, and product 1 ow rate. The bottoms rate was not metered; but it was assumed that the maintenanoe of constant feed and produot rates and oonstant 11 quid level in the roboller would render the bottons rate caloulable. Mis assumption required that colum holdup be essentially constant; and th1s should occur under normal operating conditions. Sample operational data sheets for experimental work are presented in figures 5,6 , and 7 .

Samples were analyzed by methods chosen for the system under investigation, and the data were used in calculation of the efriolency of eractionation. Efflolenoy, es used in this report is defined as the ratio of the number of theoretioul plates reguired for a given separation, to the actual number of plates used for that separation. The caloulation of the theoretical number of plates was accomplished by the step-by-step procedure of Mocabe and Thlele (19) on a plot of the vapor 11quid equi11br1a. Vepor-11quid equilibri were plotted on $20^{\prime \prime} \times 20^{\prime \prime}$ oross section paper exoept when acouracy in low-oomposition ranges required the use of alot on $10 \mathrm{~g}-10 \mathrm{~g}$ paper $(20)$. Prior to efflelency caloulations on each run a plot was made of the plate sample composition versus its placement 
IABORATORY EXPER IMENTAL DATA

Run No. systom Acetone - water

rypo of operation Continuers Columa Date 11 Feb.194Z

started column _ $\ldots$. Contiseatein of Run $\# 49$

Total Reflux 웅 .$M$.

Feed to plate No. $12: 00$ A.M.

Product over \& CZiQSPM., bottoms over MiQS P.M.

Samples and temperature readings $1: 10$ P.M.

Stean pressure 10 P.s.i. gago

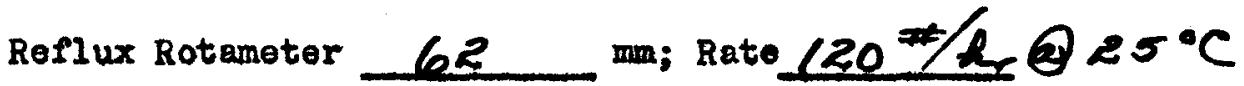

Product Rotameter 20 m; Rate $80 \% / \mathrm{f} @ 25^{\circ} \mathrm{C}$

Food Rotameter 200 mate Rat $115^{\circ / / 2} @ 50^{\circ} \mathrm{C}$

sample Speaifie fe Mol \% 11ght key Plate Temp. 'C.

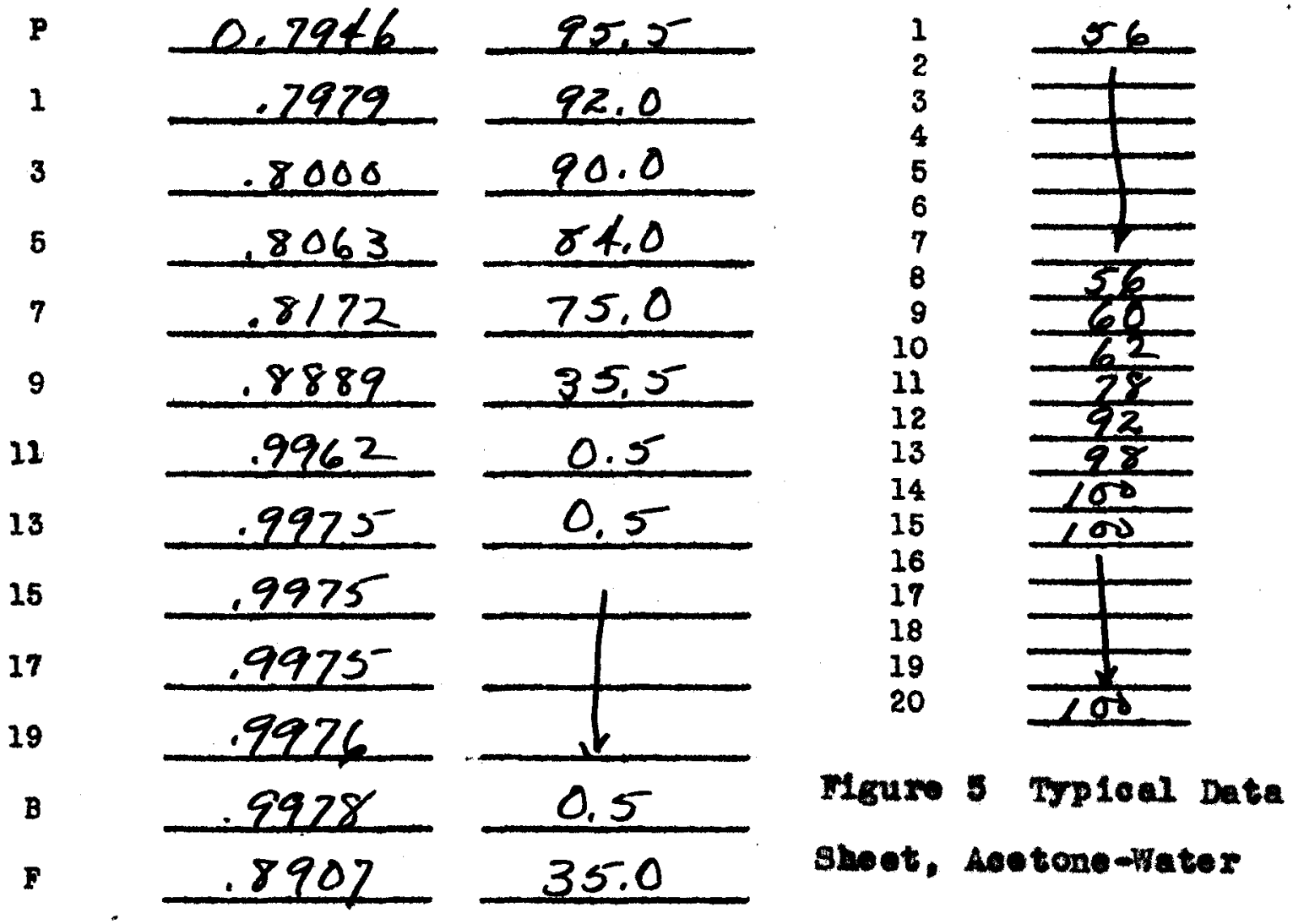


Run No. 70 system MEK-weter

Started Column - 1i40 P.M.

Total Reflux $2: 1 / 0$ P.M.

Feed to plate No. 3 2:21 P.M.

Product over 2:25P M., bottoms over 2:25 P.M.

Samples and temperature readings $3: 15$ P.M.

Steam pressure 8 p.s.1. gage

Reflux Rotameter ___ mate

Product Rotameter 58 mi Rate $49 \# / 2$

Foed Rotameter ___ Rate 39.18/hr. (a) $74^{\circ} \mathrm{C}$

samplo Freesing Pt. Mol \% light key Plato Tomp. ${ }^{\circ} \mathrm{C}$.

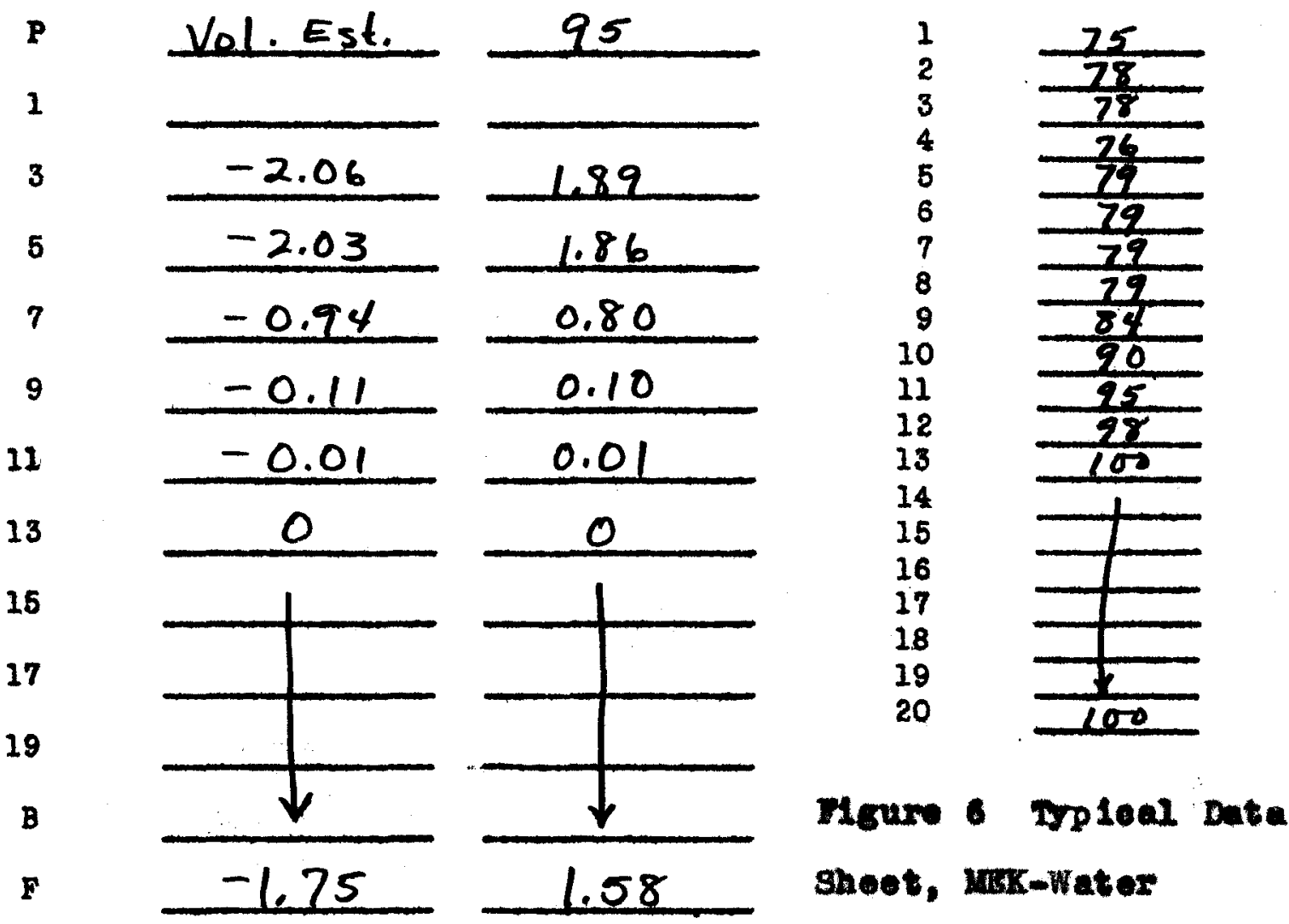


32

LABORATORY EXPERIMENTAL DATA

Run No. 85 system Pentome-toluens...Type of operation Contericeus Stripping Date 29 April, 1947

started column $3: 15$ PoM.

Total Reflux $3: 40$ P.M.

Feed to plate No. 9 3:46 P.M.

Product over $3: 55 P$ Al, bottoms over 3:55 P.M.

Samples and temperature readings $4: 20 P . M$.

Steam pressure $\frac{18}{18}$ p.s.1. gage

Reflux Rotemeter 25 ; Rate $23 \% / \mathrm{h}$

Product Rotameter 20 mim; Rate $18^{*} / \mathrm{h}$

Feed Rotameter 200 mm; Rate $110^{*} / \mathrm{h} \otimes 25^{\circ} \mathrm{C}$

sample Specific $G_{x}$ Mol \% light key plato Temp. ${ }^{\circ} \mathrm{C}$.

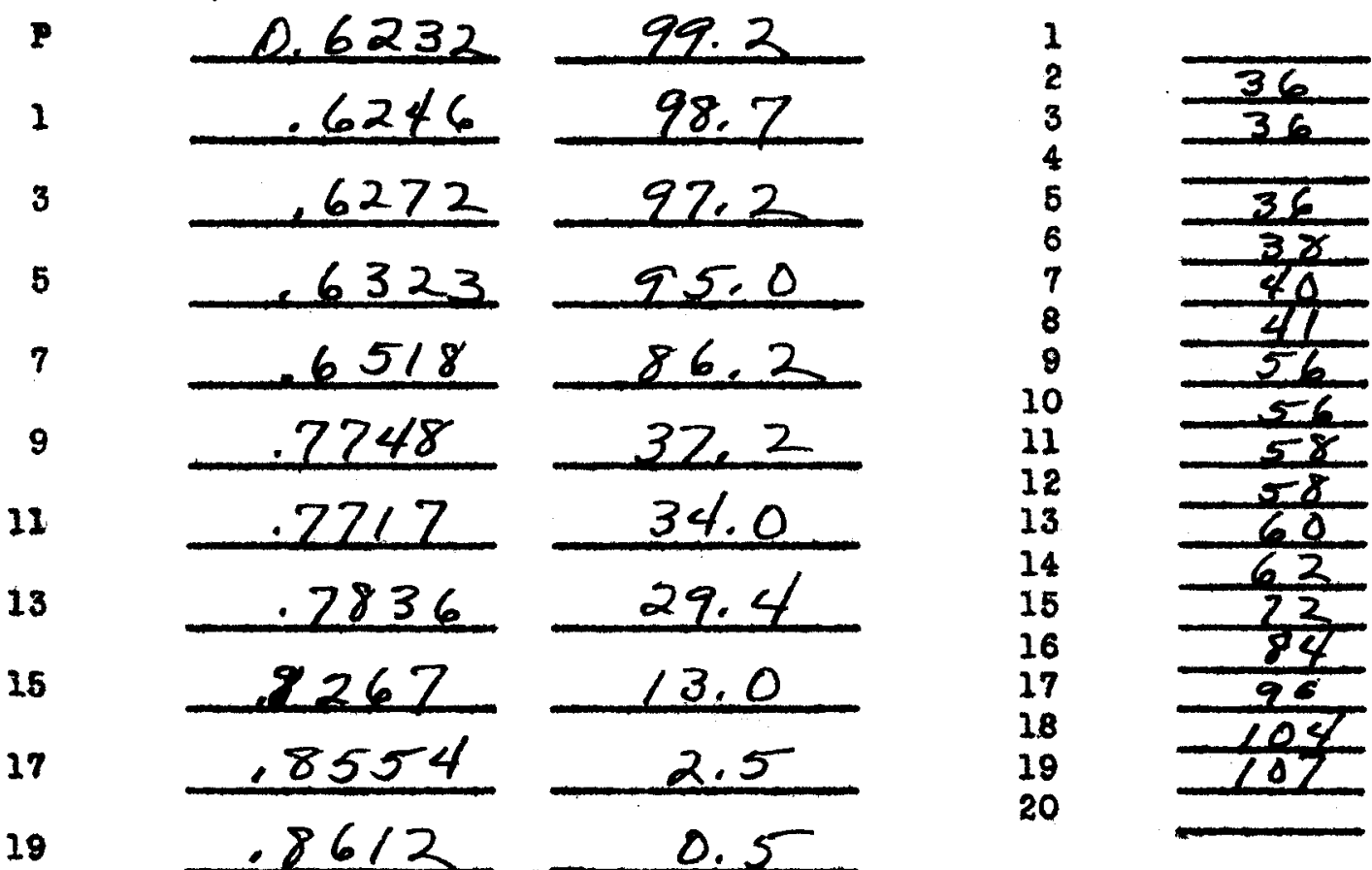

B

.8612

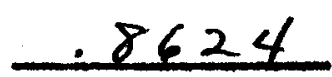

$\mathbf{F}$
0.5

.8146
$>0.5$

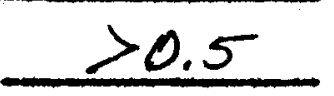

17.2
Figure 7 Typical Data Shoot, Pontme-Toluene 
In the column so that abnormalities in distribution, foed mismatch ote. could be detected and dealt with properly.

Mere feed misnatch was evilent the abnormal data of adjacent plates were not used in calculation of reot1fler and stripper officlencles. Data on runs where foed was excessively mismatched were discarded completely. A chook on the method was made by the oaloulation of two-plate erficlencies throughout the length of the column. Where the two-plate efflolenoy deviated widely from the everage, the data were not included in calculation of the overall column efrlciency. This we especially orident in stripping sections. By this method date from the section of the column orer whioh there was good distribution were selected and used in efficiency determinations.

For correlation of results a psuedo molel viscosity was employed as suggested by Drlokemer and Bradford (14). Their method assumed that the viscosities of mixtures may be determined by adding the viscosities of the components at a given temperature in proportion to the mol fraction of each present. Viscosity values for pure components as a function of temperature were obtained fron stendard referenoes. The viscostty for oorrelation purposes was taken at an average column temperature. The value of the relative volatility for use in the correlation was obtained by a welghted integration of the actual values on plates over which results are reported. 
DATA AND RESULTS 
ACETONE-WATER

Investigation of the system acetone-water would place date in the same range as those of the methanol-water and ethenol-water systems. Howerer, since the system is of a different type than those studied by stigger ( 81 , it was included to Improve the value of the resulting correlation. Inftial work on the aystem proceeded in the same manner as that prevlousiy described. One run was made at total reflux, and a number of continuous column operations were made with a central food. Separation in the stripping section was so rapid and the system so sensitive to slight temperature and presgure changes that miamatch was erequent and stripping data were useless for initial runs. To complete the study of the system, gereral runs were made with continuous feed to the top plate, and the entire column under stripping conditions. During these last operations the rapid separation caused diffioulties in obtaining a wize distribution in the column, but efforts were made to increase the distribution by inoreasing the 11quid-vapor ratio to the limit of colum operation. Near this upper limit, a distribution of acetone was obtained over as many as seren platea.

Orer the range of compositions to be encountered In Investigation of the acetone-water system, it was found that vestphal balance denstiy measurements would give an acouracy of 0.25 mol per cent. Density composition data 
were determined in the laboratory, (Table II) and used subgequently in sample analysis.

For the initial runs this analysis was satisfactory, but for continuous stripping runs, where the acetone content of samples was very low, the preolsion was inadequate. It was declded then to use a $85 \mathrm{ml}$. pyonometer w1th a thermometer and side arm, as speolfled by AST standsa D-153-39 for density determinations. These were made at $20^{\circ} 0$. with an accuracy of 0.02 mol per oent, which was surfiolent for this part of the investigation.

Caloulations were made for the initial muns on aoetone-water by the method of kecabe and Thiele (18), from equilibrium data calculatod by Carlson and Colburn (21) and presented in Table III. However, because of the very low acetone content in stripping section samples, an extension of the method of McCable and Inlele was necessury for oaloulation of strippine efrlclencles. For these operations the applicable seotion of the equilibriun curve was transforred to $10 \mathrm{~g}-1$ og coordinate paper and oaloulations completed $(20)$.

The results for the systen are presented in Table IV and shown graphlcally in Figure 8 .

The overall and reotiflcation offlolencles appear to be in good agreament. The overall erriolenoy of run No. 50 is somewhat higher than the average result, but it is noted that the efflolenoy of the rectifying seotion of this same run egrees closely with the average. The fact that a short but very high efflolency of the stripper soction 1 inoluded 
TABLE II. ANIITICAL DATA, ACETONE-WATER

\begin{tabular}{|c|c|c|c|}
\hline Sample & $\begin{array}{l}\text { Wt } \% \\
\text { Aoetone }\end{array}$ & $\begin{array}{c}\text { Mol Per Cent } \\
\text { Aestone }\end{array}$ & Speoiflo Gravity \\
\hline 0 & 0.00 & 0.00 & 0.9986 \\
\hline 1 & 16.50 & 5.75 & .9756 \\
\hline 2 & 27.10 & 10.38 & .9600 \\
\hline 3 & 38.30 & 16.20 & .9438 \\
\hline 4 & 46.00 & 21.00 & .9262 \\
\hline 5 & 54.20 & 26.90 & .9111 \\
\hline 6 & $58 \cdot 40$ & 30.40 & .8007 \\
\hline 7 & $6 \% .60$ & 34.30 & .8913 \\
\hline 8 & 71.50 & 43.70 & .8702 \\
\hline 9 & 78.00 & 49.50 & .8502 \\
\hline 10 & 85.30 & 64.20 & .8340 \\
\hline 11 & 90.20 & 73.90 & .8197 \\
\hline 28 & 95.00 & 85.60 & .8057 \\
\hline 13 & 97.50 & 98.40 & .7974 \\
\hline 14 & 100.00 & 100.00 & .7910 \\
\hline
\end{tabular}


TABLE III. VAPOR IIQUID BQUILIBRIA, ACERONE-WATER

\begin{tabular}{|c|c|c|c|}
\hline$x_{A}$ & $y_{A}$ & $t_{b}$ & $\alpha$ \\
\hline 0.00 & 0.000 & 100.0 & 28.50 \\
\hline 0.01 & 0.225 & 93.5 & 28.80 \\
\hline .08 & 370 & 88.1 & 28.80 \\
\hline .05 & .591 & 77.8 & 27.40 \\
\hline .10 & .723 & 69.3 & 23.50 \\
\hline .20 & .797 & 63.4 & 25.70 \\
\hline .30 & .817 & 61.7 & 10.42 \\
\hline .40 & .826 & 61.0 & 7.14 \\
\hline .50 & .834 & 60.4 & 5.05 \\
\hline .60 & .847 & 59.8 & 3.68 \\
\hline .70 & .866 & 58.9 & 8.78 \\
\hline .80 & .894 & 57.9 & 2.12 \\
\hline .90 & .939 & 56.8 & 1.70 \\
\hline .95 & .966 & 56.5 & 1.51 \\
\hline 1.00 & 1.000 & 56.1 & 1.30 \\
\hline
\end{tabular}




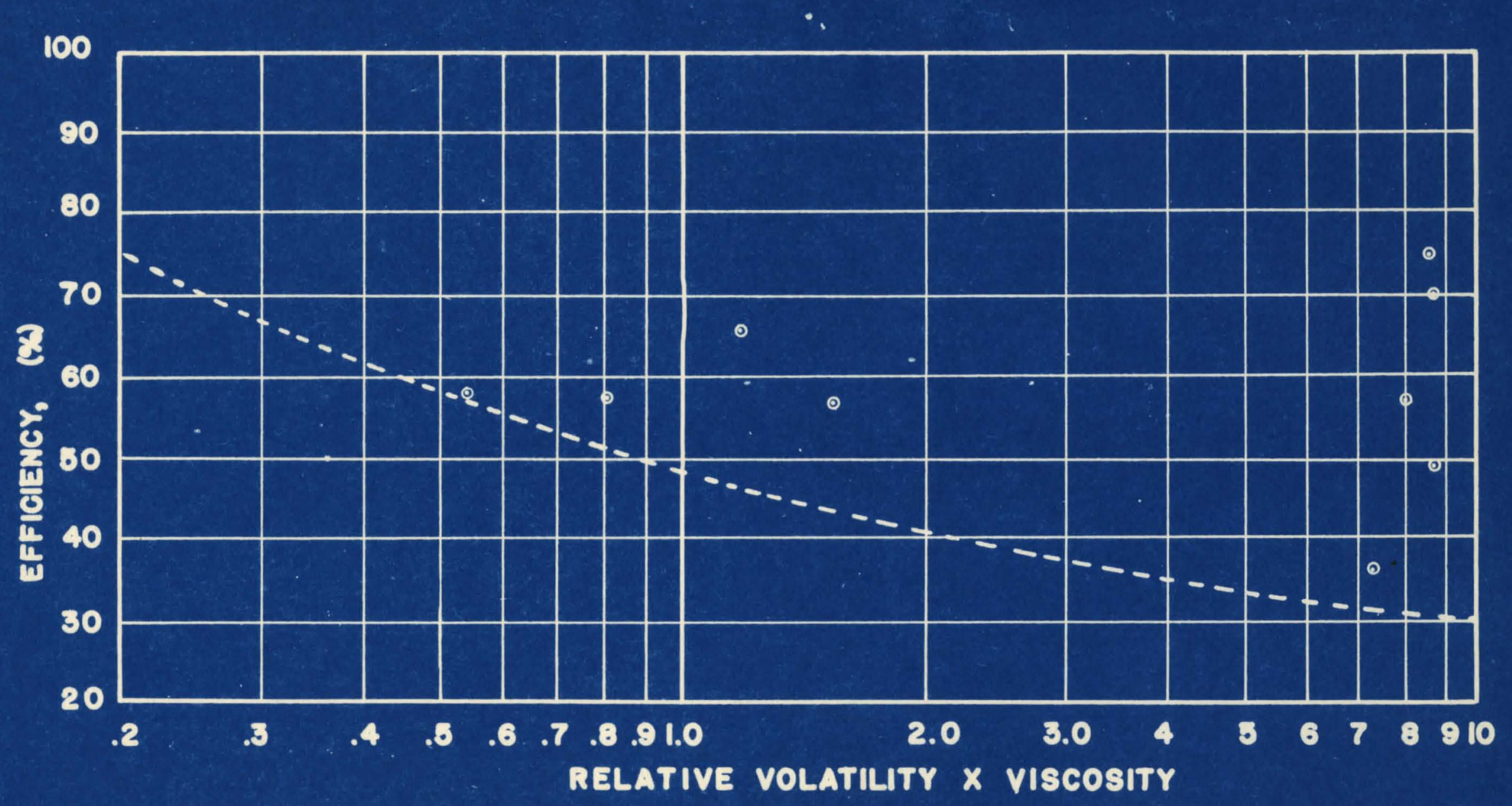

Figure 8 Effect of Relative Volatility and Viscosity on Plate Efficiency, Acetone-Water System 
TABLE IV. ACETONE-WATER SUMMARY DATA

\begin{tabular}{|c|c|c|c|c|c|c|c|c|c|c|}
\hline $\begin{array}{l}\text { Run } \\
\text { No. }\end{array}$ & Section & $\begin{array}{l}\text { Vapor } \\
\text { Veloc1ty }\end{array}$ & $\frac{L}{V}$ & $\begin{array}{l}\text { Actual } \\
\text { Plates }\end{array}$ & $\begin{array}{l}\text { No. of } \\
\text { Plates }\end{array}$ & $\begin{array}{l}\text { Theo. } \\
\text { Plates }\end{array}$ & $\begin{array}{l}\text { overall } \\
\text { Effletenor }\end{array}$ & س & $\alpha$ & $\mathrm{nd}$ \\
\hline 49 & Col. & 0.86 & 1.00 & $9-1$ & 8 & 4.52 & 57 & 0.33 & 4.7 & 1.54 \\
\hline 50 & Reot. & 0.79 & 0.60 & $9-1$ & 8 & 4.60 & 58 & .30 & 2.7 & 0.81 \\
\hline 50 & Col. & & 0.60 & $11-1$ & 10 & 6.60 & 66 & .32 & 3.8 & 1.22 \\
\hline 52 & Rect. & 1.00 & 0.90 & $9-3$ & 6 & 3.48 & 58 & .27 & 2.0 & 0.54 \\
\hline 56 & strip. & 0.49 & 6.40 & $7-1$ & 6 & 3.40 & 57 & .88 & 28.5 & 8.00 \\
\hline 57 & Strip. & 0.50 & 8.90 & $13-3$ & 10 & 7.00 & 70 & .30 & 28.5 & 8.70 \\
\hline 58 & strip. & 0.37 & 8.70 & $11-7$ & 4 & 1.95 & 49 & .30 & 28.5 & 8.70 \\
\hline $61 A$ & Strip. & 0.78 & 3.57 & $9-3$ & 6 & 2.17 & 36 & .30 & 23.8 & 7.26 \\
\hline 68 & strip. & 0.39 & 10.07 & $7-5$ & 2 & 1.20 & 75 & .33 & 86.15 & 8.63 \\
\hline
\end{tabular}


in the overall figure may be the cause of the deviation. The average of overall and rectifier or flclencies was not as closely represented by the proposed correlation as were the results of Stigger's experimentation (8), but it is in the same region and, then compared with the previous data, falls within allowable 1infts of engineering accuracy. There is no correlation between stripping erficlencies and visoosityrelative volat1lity product except at low reflux ratios as in run No. 61-A. Th1s fact substantlates the previous supposition that the effect of the $\frac{I}{V}$ ratio is of Importance in determining plate effiolonoy. 
METYL BTHL TETONE-WATER

For the inclusion in the correlation of a partially miselble aystem of a dfferent type, and with a viscosity-relative volatility product in the uppermost region or the range to be covered, the system methyl ethyl ketonewater was chosen.

Because of the low solubility it was not possible to operete the column under reotifloation conditions without entering into a double 11 quid phase relationship. This necessitated the confinement of operations to stripping runs alone. Hero again it was necessary to operate at a high reed rate in order to obtain good oolum distribution of components. This raised the liquid vapor ratio to a high flgure, but under these conditions distribution was obtained over as many as elght plates. In operation of the column on this system equilibrium confitions were extremely diffioult to obtain becauge of the high sensitivity of the gystem to slight changes in calandria steam pressure. A slight drop In steam pressure caused depletion of 11quid on the plates, wh110 alight upward variation caused bulld-up in the column. A high foed rate limited the time allowed for obtainIng equilibrium conditions to not more than one hour, and made it necessary to d1 soard much of the data for muns adversely afreoted by stean pressure variations.

In the low methyl ethyl ketone conoentrations there was such short range of verlation that a highly 
accurate method of analysis was found necessary. Therefore, a freezing point mothod, using the Beckman freezing point apparatus and uffording an acouracy of 0.02 mol per cent, was chosen and employed for analyses using data determined in the laboratory, Table V.

TABLE V. ANALYTIC L DATA, METHYL BTTY XETONE-HATER

\begin{tabular}{|c|c|c|c|}
\hline Sample & $\begin{array}{c}\text { Weight Per Cent } \\
\text { Ugex }\end{array}$ & $\begin{array}{c}\text { Mol Per Cont } \\
\text { MRK } \\
\end{array}$ & $\begin{array}{l}\text { Freezing } \\
\text { Polnt. }{ }_{0} \text {. }\end{array}$ \\
\hline 1 & 0 & 0 & 0 \\
\hline 2 & 3.22 & 0.83 & -0.97 \\
\hline 3 & 6.50 & 1.71 & -1.89 \\
\hline 4 & 9.84 & 2.66 & -8.80 \\
\hline 5 & 13.22 & 3.67 & -3.67 \\
\hline
\end{tabular}

The product was composed of two immlsolble lavers; 1ts composition was estimated volumetrloally for purposes of obtaining a material balance on each run. Aotual product concentration, for purposes of caloulating efficlencles, was oaloulated from material balance over the column, from known feed composition and rate, and from effulent rates. The 10 w concentration of methyl ethyl ketone In the samples necessitated the use of the $\log -\log$ extension (28) of the Mocabe Thiele diagram for calculation of theoretioal plates. Equilibria data for these determinations were caloulated by the method of Carlson and Colburn (21) for immiscible syatems, Table VI. 
TABLE VI. VAPOR LIQUID EQUILIBRIA, METHY ETHYL KETONE-WATSR

\begin{tabular}{|c|c|c|c|}
\hline$x_{h}$ & $\mathbf{Y}_{\mathrm{A}}$ & $t_{b}$ & $\alpha$ \\
\hline 0.00 & 0.000 & 100.0 & $\ldots$ \\
\hline 0.01 & 0.355 & 88.5 & 54.50 \\
\hline 0.02 & 0.513 & 81.5 & 51.60 \\
\hline 0.03 & 0.594 & 79.2 & 47.80 \\
\hline 0.04 & 0.637 & 74.6 & 42.20 \\
\hline 0.10 & 0.650 & 73.8 & 16.70 \\
\hline 0.80 & 0.650 & 75.6 & 7.43 \\
\hline 0.40 & 0.650 & 73.8 & 2.79 \\
\hline 0.60 & 0.650 & 73.8 & 1.23 \\
\hline 0.70 & 0.650 & 73.8 & 0.78 \\
\hline 0.80 & 0.710 & 74.4 & 0.61 \\
\hline 0.90 & 0.813 & 76.0 & 0.48 \\
\hline 0.95 & 0.891 & 77.7 & 0.43 \\
\hline 1.00 & 1.000 & 79.6 & $\cdots$ \\
\hline
\end{tabular}

Wo consistent trend is indioated by the data, Figure 9, when presented on a visoosity-volatility plot, nor do the results of the system when so plotted approach 0'Connell's correlation exoept in low 11quid-vapor rat1os. Thorefore, one might infer that if reotifloation operation (where $\frac{L}{V}$ is less than one) were possible with this system, the oorrelation would be more nearly applicable (page 61). 


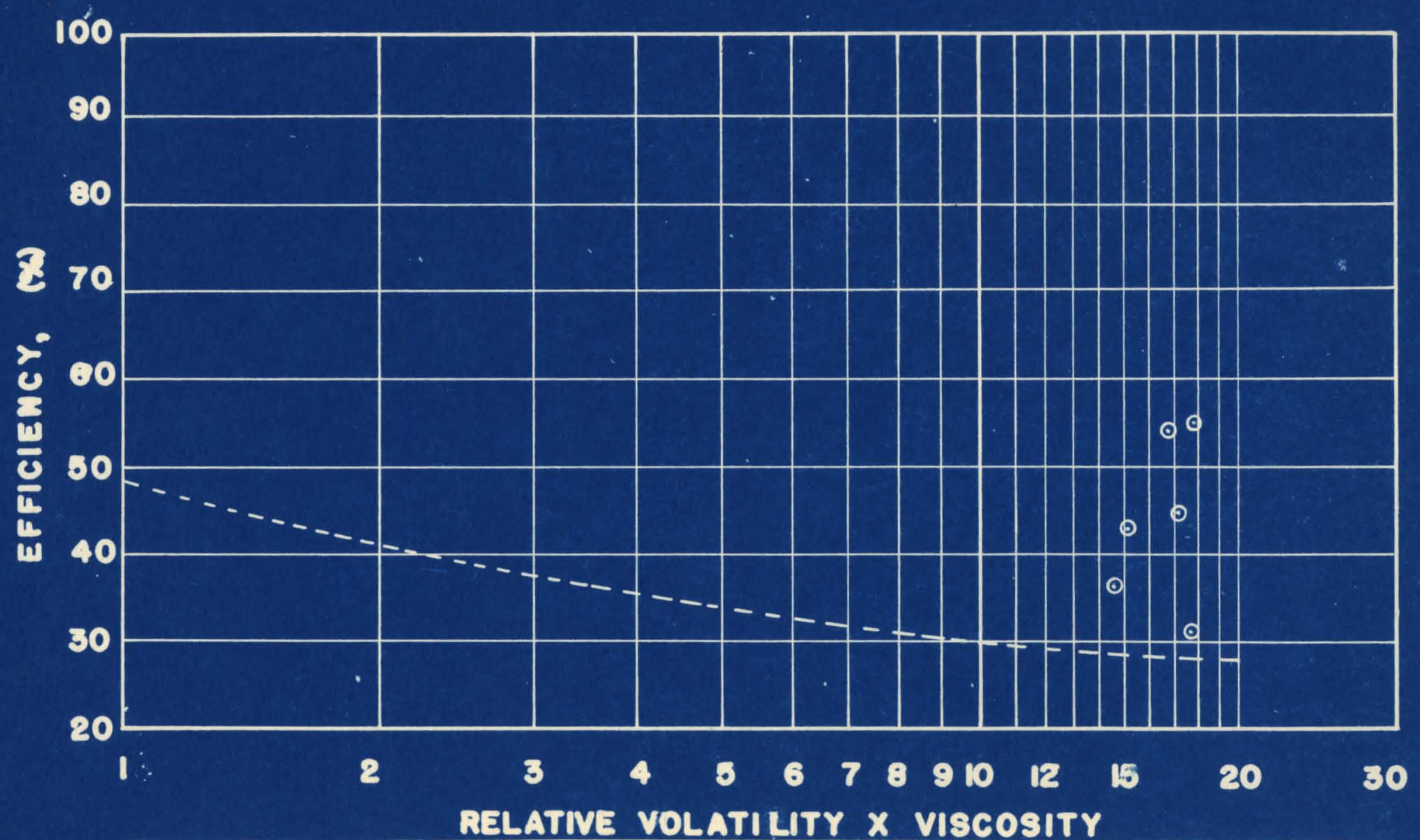

Figure 9 Effeot of Relative Volatility and Viscosity on Plate Bfficiency, Methyl Bthyl Ketone-Water System 
TABLE VII. METHY ZTHYL KETONE-WATER, SUMMLRY DATA

\begin{tabular}{|c|c|c|c|c|c|c|c|c|c|c|}
\hline $\begin{array}{l}\text { Run } \\
\text { No. }\end{array}$ & Seotion & $\begin{array}{l}\text { Vepor } \\
\text { Veloe1ty }\end{array}$ & $\frac{L}{V}$ & $\begin{array}{l}\text { So tual } \\
\text { Plates }\end{array}$ & $\begin{array}{l}\text { Number } \\
\text { of Pletes }\end{array}$ & $\begin{array}{l}\text { Theo. } \\
\text { Plates }\end{array}$ & $\begin{array}{l}\text { overall } \\
\text { Eftioleney }\end{array}$ & $\mu$ & س & $\mu \alpha$ \\
\hline 63 & strip. & 0.71 & 3.11 & $5-1$ & 4 & 1.85 & 36.2 & 0.290 & 50.0 & 14.6 \\
\hline 67 & strip. & 0.29 & 12.60 & $11-3$ & 8 & 5.80 & 55.0 & .328 & 54.4 & 17.8 \\
\hline 69 & Str1p. & 0.71 & 4.58 & $8-5$ & 4 & 1.45 & 30.8 & .328 & 54.0 & 17.7 \\
\hline 70 & strip. & 0.64 & 7.47 & $11-5$ & 6 & 3.40 & 45.0 & .325 & 53.8 & 17.3 \\
\hline 71 & strip. & 0.46 & 7.95 & $7-3$ & 4 & 2.83 & 54.3 & .310 & 54.5 & 16.9 \\
\hline 74 & strip. & 0.20 & 5.8 & $9-3$ & 6 & 2.87 & 43.3 & .310 & 48.8 & 15.1 \\
\hline
\end{tabular}


PRNTANE-TOLUENE

This system was selected to represent the correlation in medium-high ranges of the relative volatilityviscosity product. It also joins an aliphatic and an aromat10 oompound and thus extends the type coverage. axperimental work on the system was begun with a total reflux mun. Subsequent runs were made at total rerlux and continuous column operation. Peed plate locetion, foed oomposition, effluent rates, eto. were adjusted as has been explained in the general experimental procedure. A high sensitivity to slight steam variations as was also encountered with the methyl ethyl ketone-water system, made it diffloult to obtain equilibriun in each ran. Feed plate mismatch was frequent an moh result lng data were alscarded; however several successful runs were completed.

By Inspection of physical properties from data obtainable in the 11terature, It was ovident that the simpleat method of analysis which would afford an acouracy of 0.2 mol per cent was by density measurement with the vestphal belanoe. A density composition plot was made fron data obtalned in the 1aboratory. Table VIII, and used in the determInation of ample compositions.

Caloulations were based on equilibrium data calculated by the method of Lewls and Kay (21) using rugacities of the pure components ant bolling point compositions eatimated from Raoult's law, Table IX. The method of Mocabe and Th1ele (19) 
TABLE VIII. ANALYTIC.I DATA, PRNTANE-TOLUDNE

\begin{tabular}{|c|c|c|c|}
\hline Sample & $\begin{array}{l}\text { wt. \% } \\
\text { Pentane }\end{array}$ & $\begin{array}{c}\text { Nol Per Cent } \\
\text { Pentane } \\
\end{array}$ & $\begin{array}{c}\text { Specific Gravity } \\
022 \mathrm{Deg} . \mathrm{C} \\
\end{array}$ \\
\hline 1 & 0.00 & 0.00 & 0.8620 \\
\hline 2 & 12.30 & 13.5 & .8256 \\
\hline $\mathbf{s}$ & 20.80 & 22.7 & .7999 \\
\hline 4 & 26.90 & 29.2 & .7839 \\
\hline 5 & 29.55 & 32.0 & .7778 \\
\hline 6 & 31.40 & 33.7 & .7716 \\
\hline 7 & 37.30 & 39.9 & .7562 \\
\hline 8 & 44.90 & 47.7 & .7399 \\
\hline 9 & 48.60 & 52.3 & .7288 \\
\hline 10 & 54.60 & 57.2 & .7163 \\
\hline 11 & 61.90 & 64.5 & .7086 \\
\hline 12 & 74.60 & 76.7 & .6728 \\
\hline 13 & 82.90 & 84.6 & .8553 \\
\hline 14 & 90.50 & 91.5 & .0434 \\
\hline 15 & 100.00 & 100.0 & .6210 \\
\hline
\end{tabular}


was used for determination of overall efficiencles using a 20" $x$ 20" plot of the equilibria data.

TABLE IX. VAPOR LIQUID EQUILIBRIA, PBNTWE TOLUMNE

\begin{tabular}{|c|c|c|c|}
\hline$x_{a}$ & $\mathbf{Y}_{\mathbf{a}}$ & $t_{b}$ & $\alpha$ \\
\hline 0.0017 & 0.0126 & 110 & 6.65 \\
\hline .0520 & .2710 & 100 & 7.10 \\
\hline .1080 & .4730 & 90 & 7.45 \\
\hline .1910 & .6400 & 80 & 7.85 \\
\hline .2880 & .7640 & 70 & 8.17 \\
\hline .4100 & .8550 & 60 & 8.52 \\
\hline .6030 & .9880 & 50 & 8.70 \\
\hline .8580 & .9790 & 40 & 7.13 \\
\hline
\end{tabular}

Resulta for the systen are presented in Table $X$ and are shown graphically in Flgure 10. W1th the exception of runs 79 and 83 the overall column efflcienoles were in exoellent agreement. It is further evilent that these two ming have the greategt deviation fron the correlation of o'connell. It will be noted that these defficienoles are higher than for the other runs and represent runs in which the average $\frac{1}{V}$ rat lo was correspondingly high. Rectifler efflotencles are well represented by the oorrelation, but except for run No. 84, stripping efficlencles deviate widely. 
TABLE $X$, PANTANE-TOLUENS SUMARY DATA

\begin{tabular}{|c|c|c|c|c|c|c|c|c|c|c|}
\hline $\begin{array}{l}\text { Run } \\
\text { No. }\end{array}$ & Seotion & $\begin{array}{l}\text { Vapor } \\
\text { Veloo1ty }\end{array}$ & $\frac{\mathrm{L}}{\mathrm{V}}$ & $\begin{array}{l}\text { Actual } \\
\text { Plates } \\
\end{array}$ & $\begin{array}{l}\text { No. of } \\
\text { Plates }\end{array}$ & $\begin{array}{l}\text { Theo. } \\
\text { Plates }\end{array}$ & $\begin{array}{l}\text { Overall } \\
\text { Efe. }\end{array}$ & $\mu$ & $\alpha$ & $\underline{\mu}$ \\
\hline 77 & Col. & 8.35 & 1.000 & $(21-3)$ & 8 & 3.50 & 43.8 & 0.26 & 8.65 & 2.25 \\
\hline 78 & col. & 0.25 & 1.000 & $(13-7)$ & 6 & 2.93 & 49.0 & 0.20 & 7.80 & 1.56 \\
\hline 79 & Col. & 1.39 & & $(19-3)$ & 16 & 8.40 & $5 \% 5$ & .27 & 8.75 & 8.36 \\
\hline 79 & Reot. & & 0.460 & $(13-3)$ & 10 & 4.00 & 40.0 & .22 & 6.90 & $1.5 \%$ \\
\hline 79 & strip. & & 2.380 & $(19-13)$ & 6 & 4.00 & 66.6 & .27 & 7.35 & 2.98 \\
\hline 83 & Col. & 2.90 & & $(11-1)$ & 10 & 5.60 & 56.0 & .28 & 8.60 & 2.45 \\
\hline 83 & Rect. & & 0.590 & $(7-1)$ & 6 & 2.70 & 45.0 & .26 & 8.40 & 2.18 \\
\hline 83 & Strip. & & 1.730 & $(11-7)$ & 4 & 2.75 & 69.0 & .28 & 7.45 & 2.12 \\
\hline 84 & Col. & 0.70 & & $(19-5)$ & 14 & 5.00 & 35.7 & .27 & 8.60 & 2.36 \\
\hline 84 & Rout. & & 0.640 & $(13-5)$ & 8 & 3.70 & 46.2 & .22 & 7.30 & 1.64 \\
\hline 84 & Strip. & & 1.580 & $(29-i n)$ & 2 & 1.90 & 45.0 & .29 & 8.40 & 2.48 \\
\hline 85 & 0.1. & 1.14 & & $(18-1)$ & 18 & 7.70 & 42.7 & .27 & 8.75 & 2.36 \\
\hline 85 & Rect. & & 0.561 & $(9-1)$ & 8 & 3.20 & 40.0 & .31 & 7.00 & 1.64 \\
\hline 85 & Strip. & & 2.25 & $(19-13)$ & 4 & 2.7 & 67.5 & .31 & 7.50 & 2.32 \\
\hline
\end{tabular}




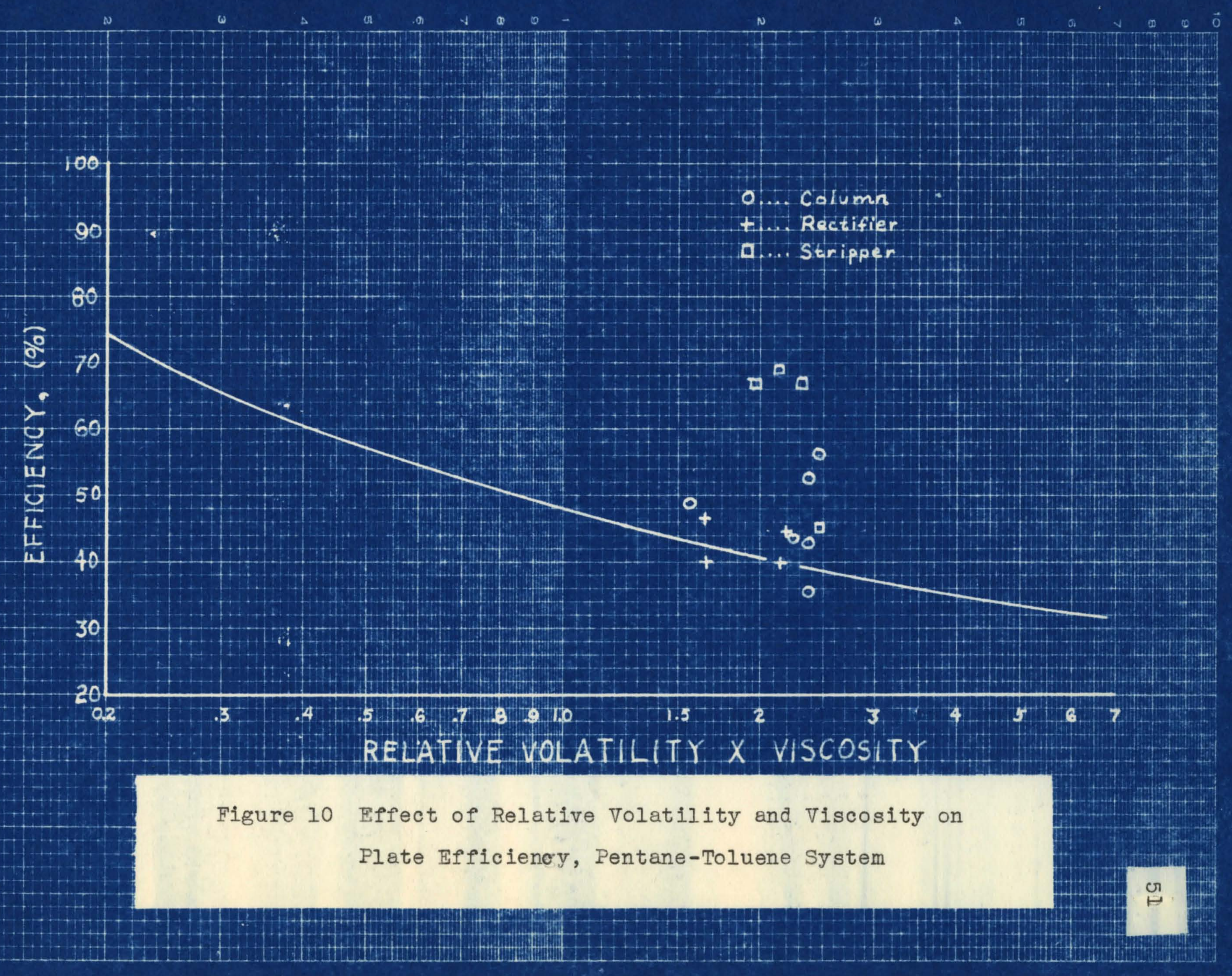


CORRELATION AND DISCUSSTON OF RESULTS 
Data have been colleoted from all the systems studied, both by stigger and by this investigator, and presented in Figure 11 for comparison with the correlation developed by o'Connell. The range of the correlation has been extended to include relative volatility-viscosity products rrom 0.2 to 40.0 .

The most widely divergent results represent operation at stripping conditions, and at orerall column operation wherin large strippling gections were contalned. This divergence has been repeatediy observed during the investigation of the varlous systems. On stripping sectIon the 11quid-vapor ratio varled from one to values as high as 15, with resulting proportionate increase in the divergence of results from those of rectiflcation, where the reflux ratio was in the nelghmorhood or one. This observation led to the conclusion that the magnitude of the 11quid-vapor ratio had a profound influence on plate efficiencies in diatiling operations.

To 1llustrate this conclusion Figure 12 was plotted from data taken from rectifying sections of runs made on each system. The 11quid-vapor ratio varied on these operations from 0.6 to 1.0 , a narrow range as oompared to that for stripping operations. The agreement of the results from data obtained from rectifying sections Is excellent. It is approximated very closely by the ourve of the correlation developed by c'connell. 


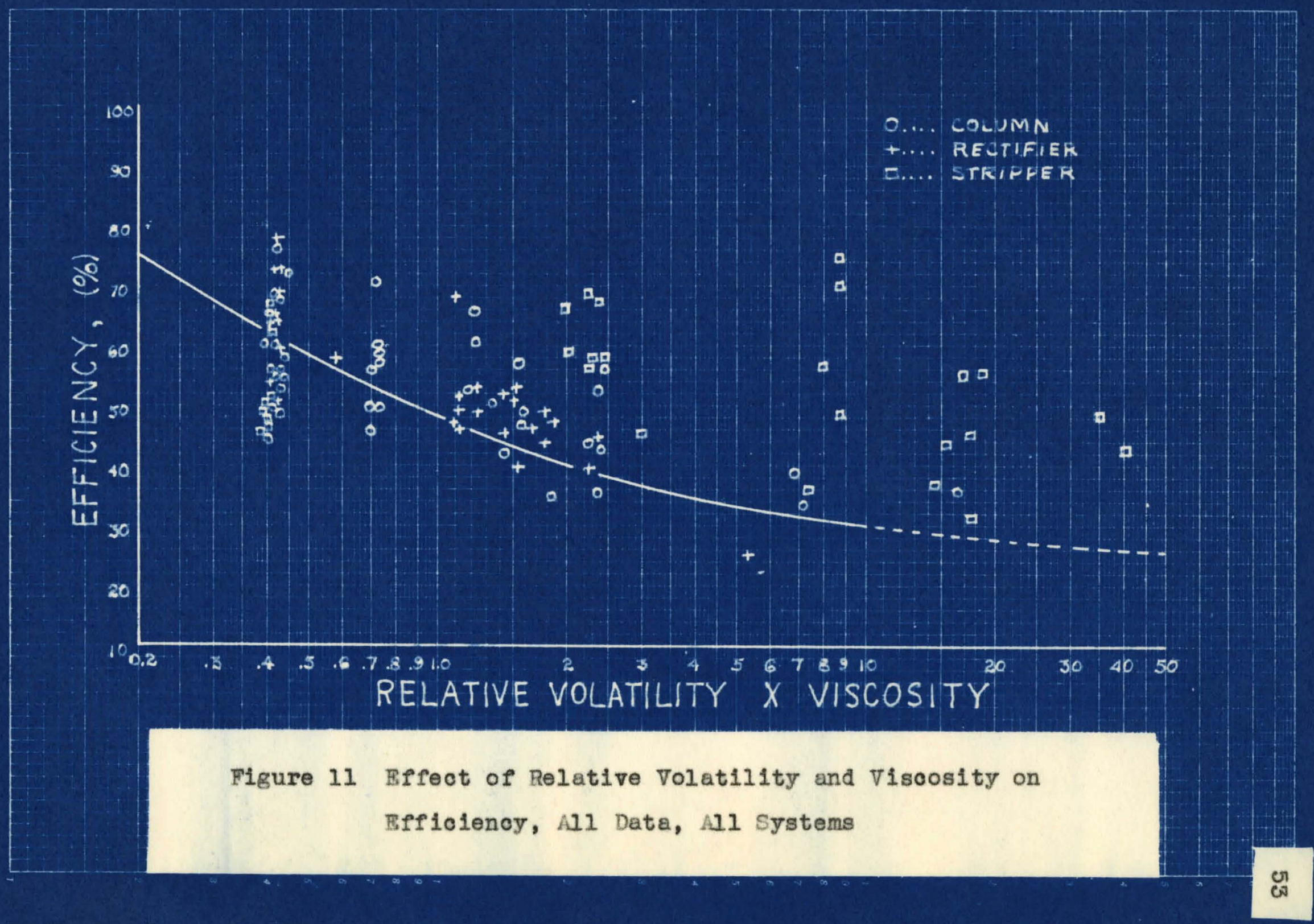




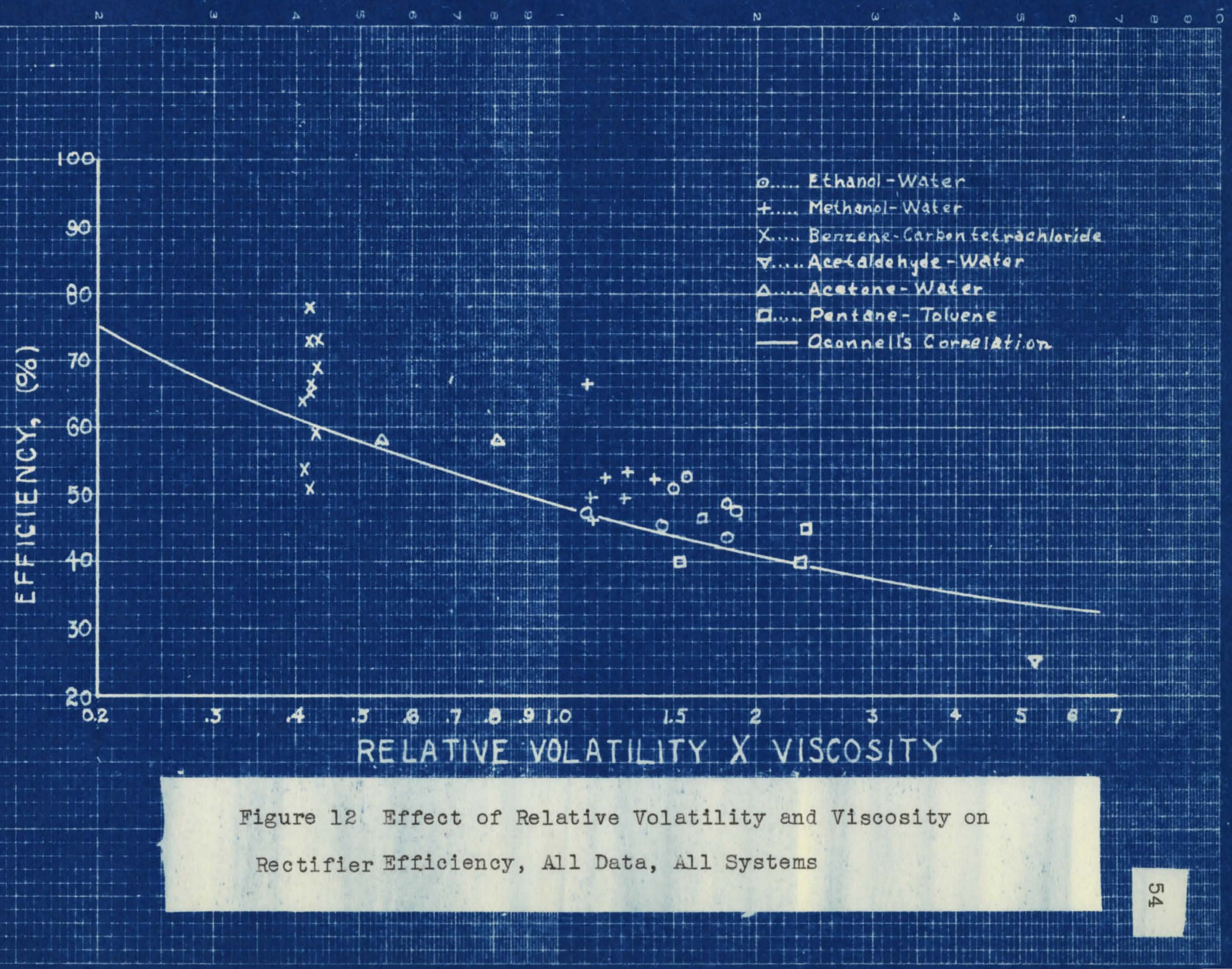


In contrast with those results Figure 13 shows no agreement between stripping efflolencles for all runs and the correlation proposed by O'Connell. This graphic representation showing the non-agreement of stripping efficlencies and their deviation from the oorrelation which holds for reotifloation efflolenoies is striking evidenoe of the effect of the IIquid-vapor ratio in frsctionation effleiencies.

In order to determine the consistency of the effeot of $\frac{\mathrm{L}}{\mathrm{V}}$ on the systems used in this investigation, It was declded to analyze the data for the firo systems inveatigated by StIgger, as well as those included in this report. There follows a summary of the results of this analysis for those systems which ylelded applicable data.

Recalculation of the results presented for methanol-water ylelded 11quid-vapor ratios for otripping sections as well as for the rectifier. This procedure mado it poseible to extend the relation, Figure 4 , to Inolude Ilquid-vapor rat10s greater than one. The result1ng plot of the effiolency as a runction of $\frac{L}{\nabla}$, Figure 14, Indioates conclusively that it is quite deflnitely a faotor in the determination of plate efflolenoles. The data are not suffioient for a plot in which the $\mu \alpha$ produot is held constant, but trend is evident over the smell range in these runs. 


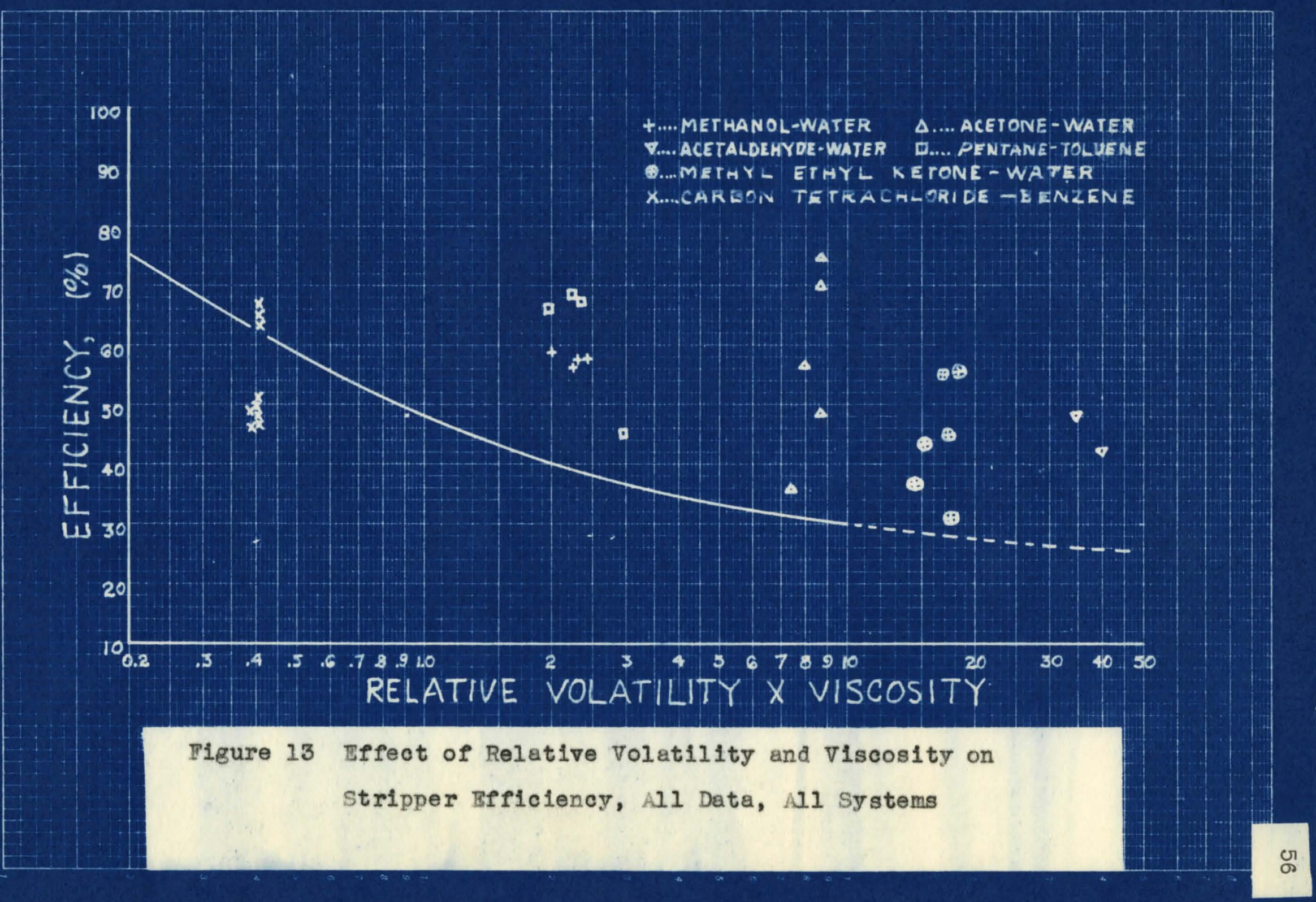




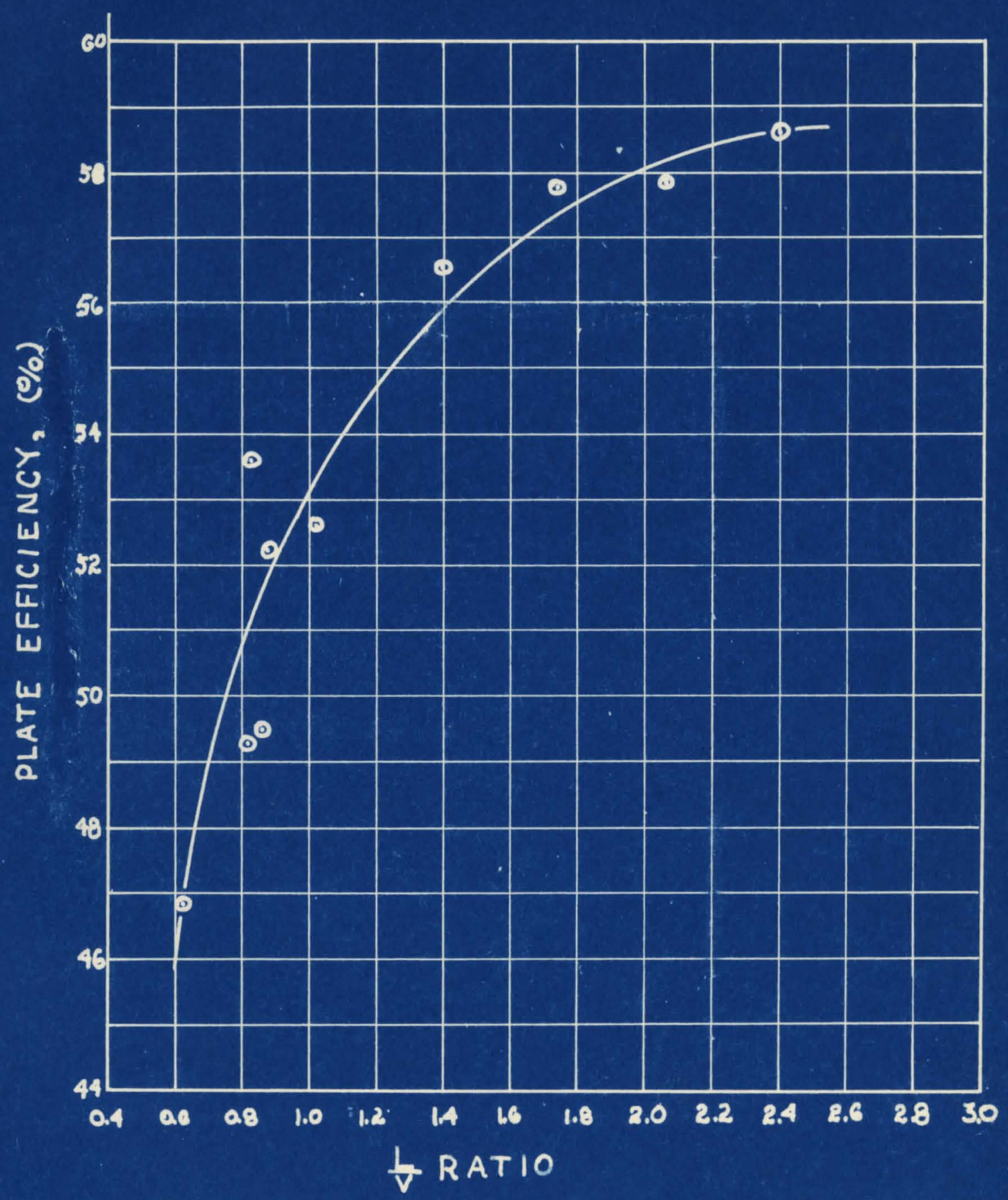

Figure 14 Effect of Liquid Vapor Ratio on

Plate Efficiency, Methanol-Water 
Although the megnitude of $\frac{I}{V}$ varied considerably with operation of the benzene-toluene system, no relation could be determined between this factor and plate erficencios.

Deviations from O'Connell's correlation were present in the results of the ourbon tetrachloride-benzene system. Here there is a relation between these deviations and the $\frac{L}{V}$ ratio, but in an opposite direction from that of methanol-water. Confirmation of this effect is shown by the plot in Plgure 15 where efficlenoy is represented as an inverse function of the $\frac{L}{V}$ ratio. Actual results for stripping conditions are below those for rectifloation, and an extension of the plot of Flesure 15 would further substantlate th1s trend.

Extreme deviations were evidenced in the high $\mu \alpha$ ranges covered by data from the acetone-water system. In an attempt to find an explanation of the deviations, a plot is presented in 1 gure 16 of stripping efflolency versus Iiquid-vapor ratio in which good correlation is obtained with the exception of run Number 58 . Because of the wide-spread range of the viscosity-volatility product over whioh the data were observed, no finfte relation can be determined from the plot, but it is evident that the 11 quid rapor ratio does have controlling influence on resulting column efficienoles in this $\mu \alpha$ range. The rolation is of the same type 


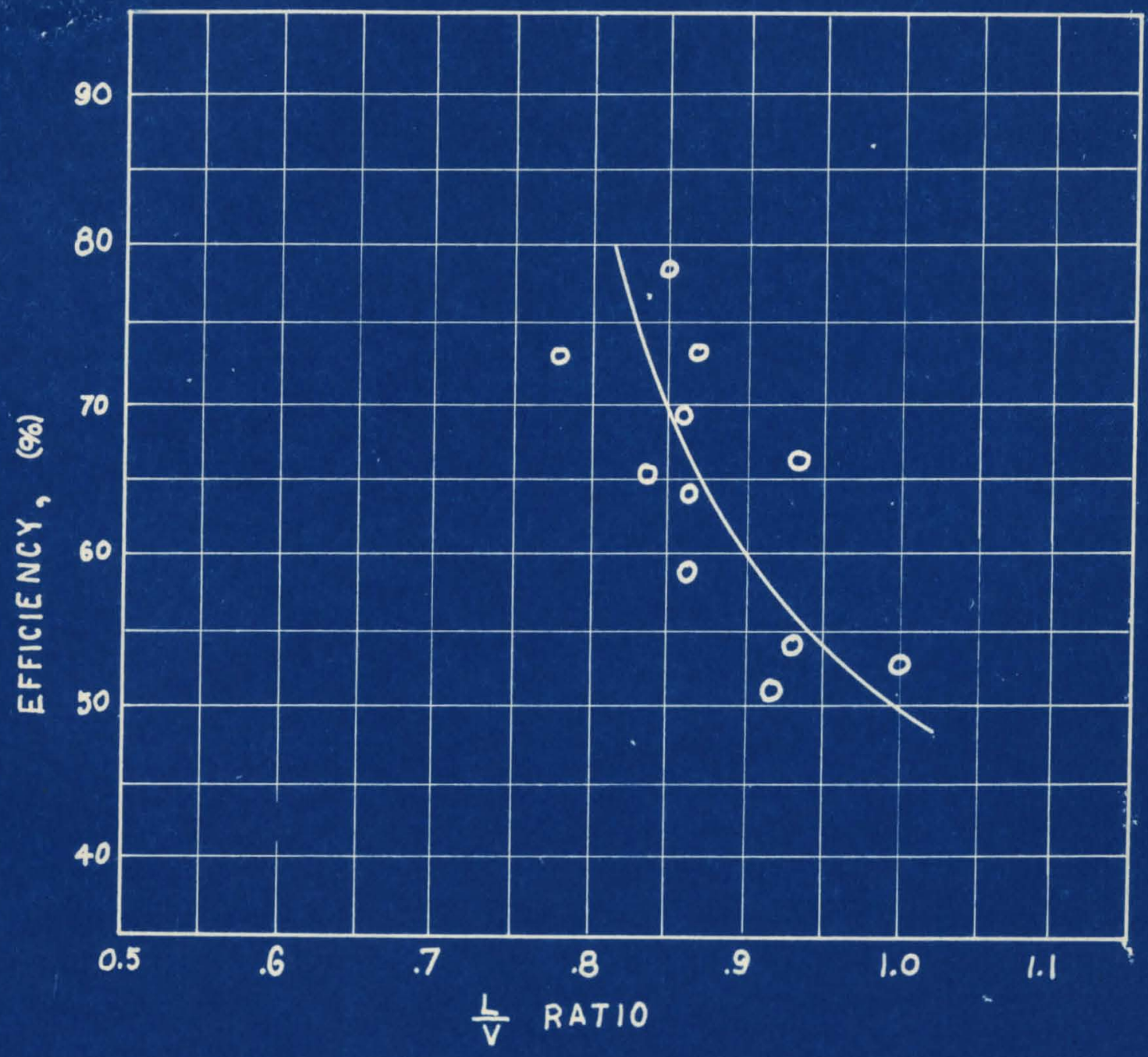

Figure 15 Effect of Iiquid Vapor Ratio on Plate Efficiency, CarbonTetrachloride-Benzene 


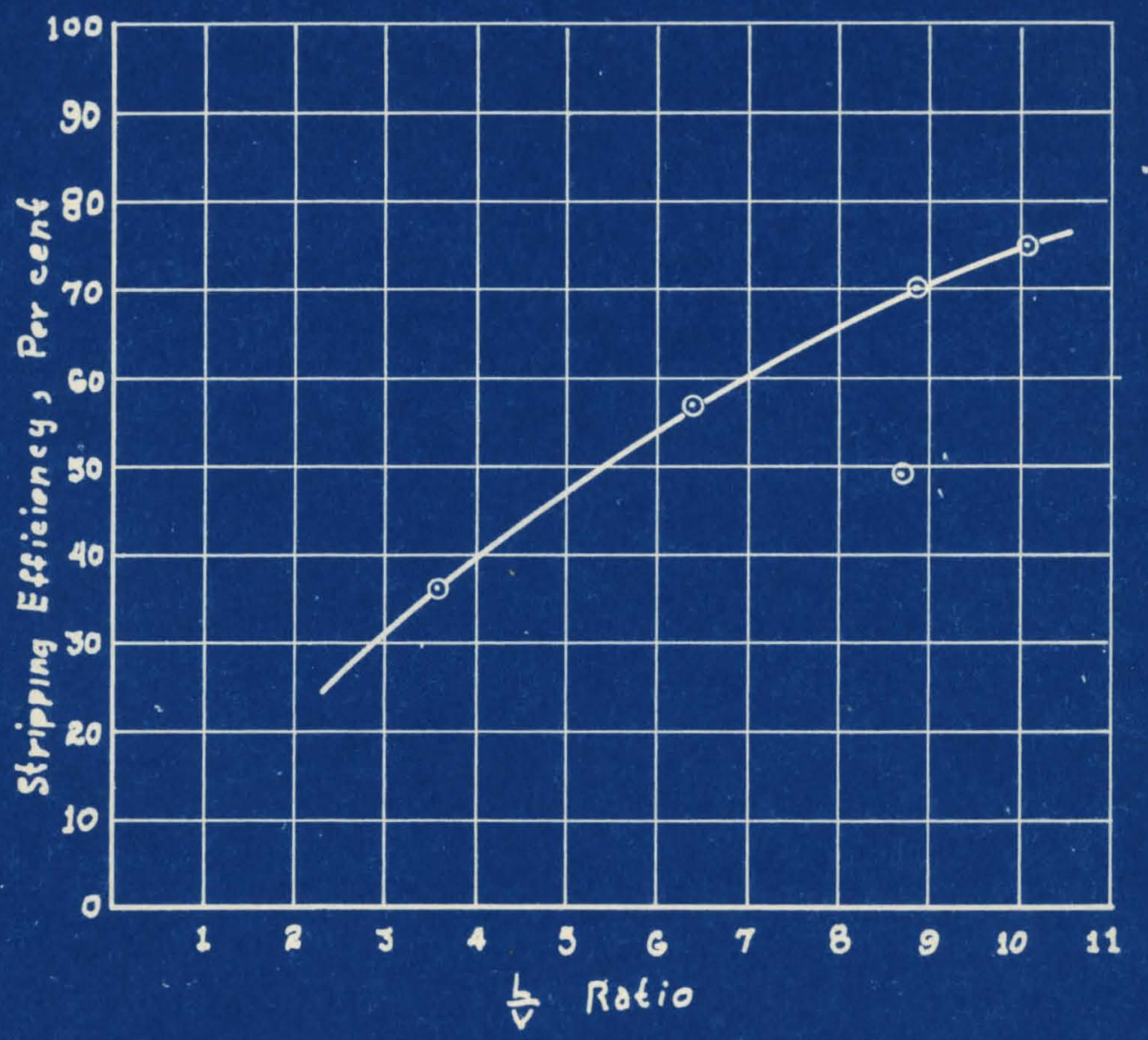

Figure 16 Effect of Liquid vapor Ratio on Stripping Efficiency, AcetoneWater System 
as that for methanol-water. Again, the deviation of results of the methyl ethyl ketone-water system from the correlation of 0 Connell was sccompanied by change in the 11quid-vapor rat1o. A plot in Figure 17 of stripping effloiency as anction of the liquid-vapor ratio shows a direct relation similar to those of methanol-water and acetone-water. In this case the range of variance of $\mu \alpha$ Is small enough to be considered constant and the eflolency Is therefore shown as a direct function of the liquidvapor ratio. For this system no rectifler sections were Inoluded, and therefore all values of $\frac{L}{V}$ are greater then one, but it is interesting that an extrapolation of the I ourve to values of $1-1.5$ result in estimated offiolencles of 20-30 per cent, range of values which is quite in keeping with the original corrolation, but not possible of demonstration by the experiments with methyl ethyl ketonewater.

For the system, pentane-toluene, a plot of efflolenoy versus liquid vapor ratio is presented in \$1gure 18. The data are inoonclusive, but again follow the trend which has been shown in other high $\mu \alpha$ product materials.

The magnitude of the product of viscosity and relative volatility appears to have a direot bearing on the effect which $\frac{L}{V}$ exerts. That 18 , in the low ranges of $\mu \alpha$, below 0.7 centipoises, the effect of an inorease 



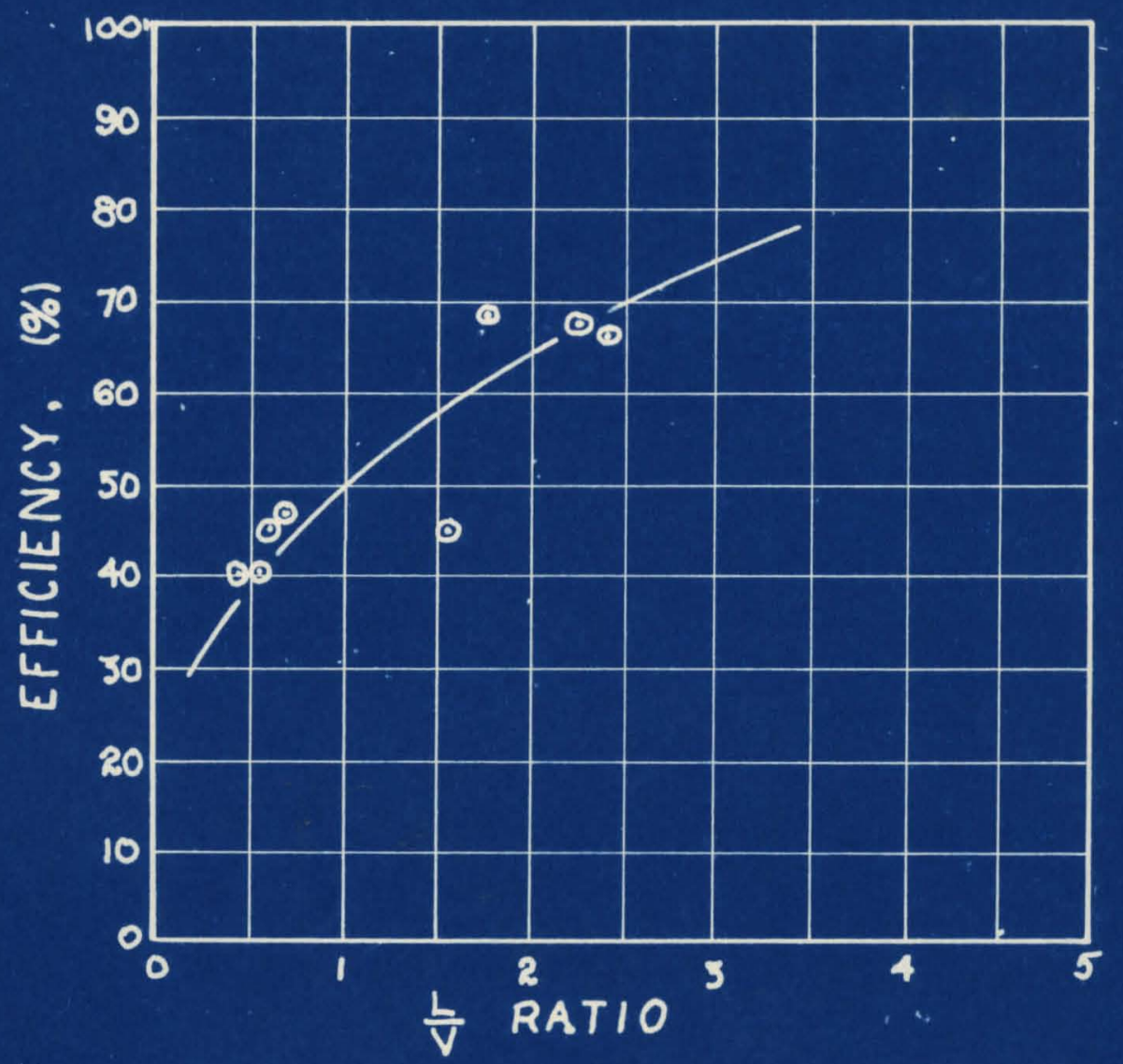

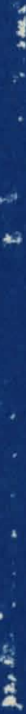

Figure 18 Effect of Liquid Vapor Ratio on Stripping Efficiency, Pentane-Toluene system 
in $\frac{I}{V}$ may decrease the efficlency (benzene-carbon tetrechloride systeml. Then in the region where $\mu \alpha$ equals 0.7 the effect of $\frac{L}{V}$ may be negligible (benzene-toluene systen). However for $\mu \alpha$ products above 0.7 the effect of an increase in $\frac{L}{V}$ is to increase the efficiency (all other systems in which $\frac{L}{V}$ varied considerably).

In view of the varled effeot of $\frac{L}{V}$ on different types of binary mixtures and the wide range of the viscosity-volatility product involved, an attempt at correlation in which the effect of $\frac{L}{V}$ is included is beyond the scope of the Investigation.

In Figure 19 is shown plot of overall column efficlenoles for the systems studied. The plotted muns inolude reotifier and etripper sections. Agreement between these results is not as olose as that between rectifler efflolencies, nor are they sis weil. represented by the correlation of 0 Connell. However, the data are In good agreement and are repreaented closely enough for englneering aoouracy by the proposed correlation. The cause of the deviation of most of the results is that stripping section data were included in the calculations, since there in 1ittle agreement between stripping section efficienoles and the correlation of o'Connell, Figure 13. 


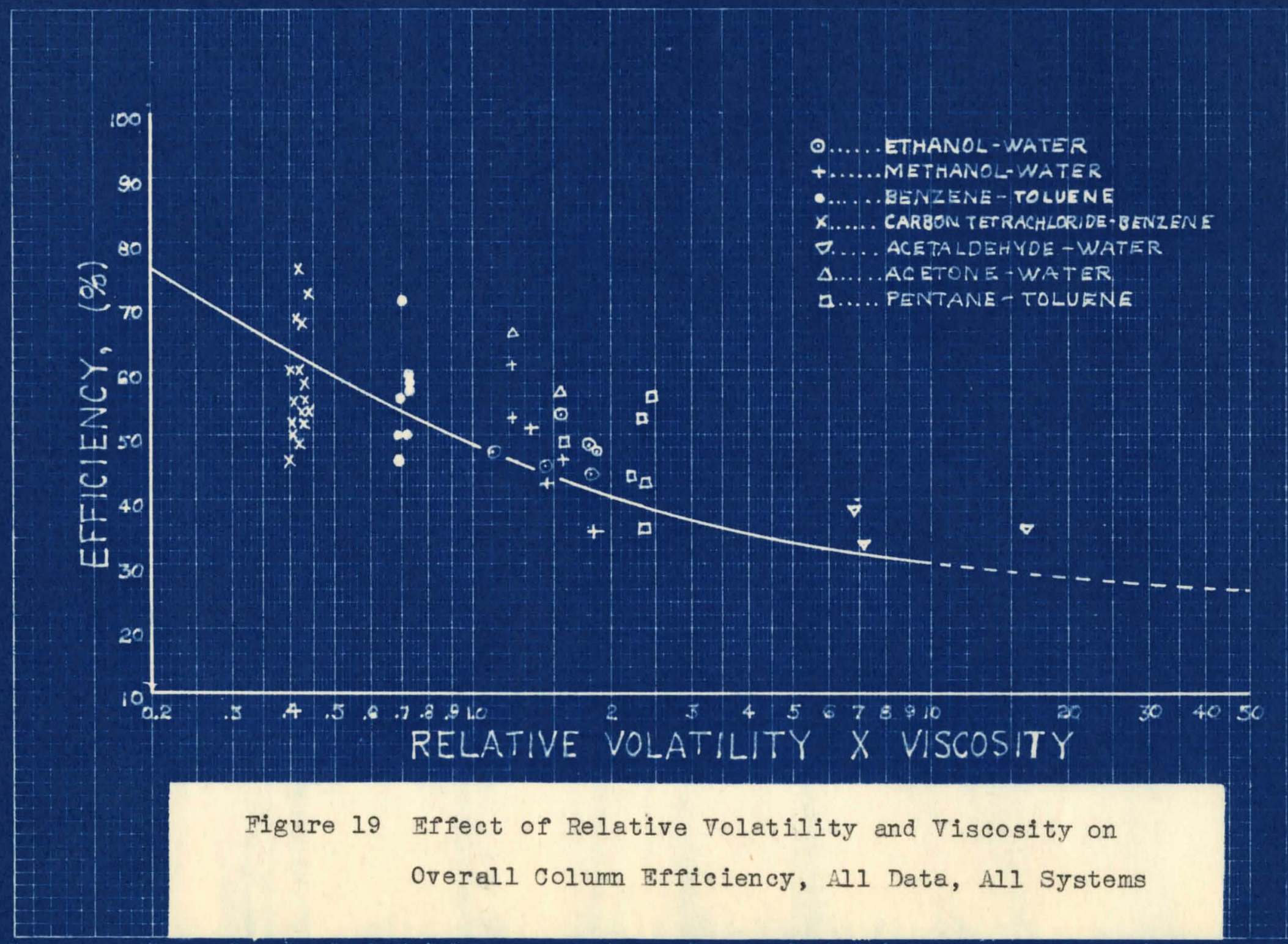


SUMMARY AND CONOLUSIONS 
overall plate efflolenoles for fractional distillation of three different systems have been presented. Reotifler, stripper, and overall column erflolencles during total reflux and contlnuous operation were correlated on the basis of the visoosity-relative volatility product, calculated at an average temperature and composition in the respective portion of the column involved. Data obtained rrom these operations we used to complete an evaluation inftiated by Stigger (8) of a correlation of column efflolenoy as a funotion of the relative rolat1lity-viscosity produot proposed by Y. F. O'Connell (5). All fraotionations were oarried out in twentyplate, ten inch, bubble cap column, with four multiple slot caps per plate. Use of the single column rinimized the effect of mechanical design faotors on the results. The column was sufficlently large to be sucoesstully used for pllot plant work and in many industrial appl1cations.

Results of the investigation ind loate that the correlation of 0 Connell, although sem1-empirical, may bo used to predict overall effolencles in commercial Practionators with certain I1mitations. For visoosityrelative volat1lity products of from 0.2 to 10.0 , offlelenofes of rectifler seotions in binary distillation can be predioted within 25 per cent by this correlation. When used for prediction of overall column efficlencles 
between the above $11 \mathrm{~m} 1 \mathrm{ts}$ the result can be expected to be within a 35 per cent error. For predictions under conditions outside these IImits, the correlation should be used with disoretion. It oannot be used for stripping effiolency work where the value of the 11quid-vapor ratio Is high, without some modifiostion to compensate for tho influence of these higher ratlos. Thls was indloated by the number and size of deviations in the value of the ratio $\frac{1}{6}$.

Definite relationships between plate efflolenoles and 11qu1d-vapor ratlo have been establishod for all the systems studied in this investigation. Graphio representations have been given for these relationships. Analysis of the results reported by stigger produced interesting relationships between $\frac{F}{V}$ and plate efricionoles which were different for different systems, and seomed to be a function of the $\mu \alpha$ product.

Though the correlation as presented has been found satiafactory for use in prediction of results on rectifler and overall column operations, there is an erident need for modifloation on the basis of $\frac{L}{\vec{V}}$ for stripping seotion work. Such modifioation would also Increase the accuracy of the prediotions of reotifler and overall column efflolency and mlght result in a finished correlation of considerably greater ralue.

The correlation proposed by 0 Connell has been 
evaluated and the types of systems have been expanded. Ithough the entire investigation involved the use of binary systems the expansion to include multi-oomponent fractionations is practical, since the original development of the correlation included mult1-oomponent separations. 
II. FACTORS AFHETING PLAT BPTCIBNCY INTRODOC TION 
Chemical englneering and the lesign of chemical equipment have been treated summarily in the 11terature, in acoordance with the relative importance of the various branches. Iren so, the Individual branches of equipment design have not recelved the theoretical conslderation commensurate with the thoroughnes they deserve. One reason for the insuffiolent treatment of the all-important fleld of distilation is that manufaoturing requirements have kept commercial practioe well ahead of theory. The purpose of this investigation is to conbine and clarify some of the information presented in the ifterature and to present method of attack for future research on the subject.

The necessity for an investigation of the factors which affect plate efflolencles obtained from bubble plate fractionators has been brought about by the Increasing disagreement between investigators as to the effect of these factors, and the consequent lack of absolute knowledge. It is evident that the present information is insufficient to permit designs which would produce opt1mum results for dist1lletion operations. To alleviate this stuation it was apparent thut the necessary investigation should begin with a study of the fundamental prinelples of ilstillation and their application to practice.

The broad soope of the problem indleated that 
the work should include a thorough search of the l1terature to determine the points at which there is most disagreement as woll es to obtain a.general knowledge of data as obtained by other investigutors and to fao111tate the correlation of future results. It was the plan of the author that the conclusions of the literature survey be ut1lized in the design and operation of a basic, single slot bubble plate to be used for collection of experimentel datu. 
HISTORICAI AND THEORETICAL 
Presented in this section are discussions of the findings of Inrestigator on number of the factors affeoting bubble plate fractionation efflolenules. For simplification and ease of reference these findings are presented under the desoriptive titio of each factor disoussed. The factorg investigated are presented in Table XI, but the position in the seguenoe is not diotated by relative importance or interrelationships.

TABLE XI, FACTORS AFTEOTIM PYATE BPHTCISNCISS

1. Hyaraulio sotion

2. Concentration cradient

3. Intrainment and plate spacing

4. Vapor Load (Velocity)

5. Reflux Rat10

6. Submergence

7. Ilquid concentration

8. Visoosity of Iiquid

9. Relative Volatility

10. Mass Transfer Phenomena

HYDRAILIC ACTION

The design of any distillation unit in whioh there is to be liquid moving over a plate and simultaneously subjected to contact whth rapor by a bubbling action, requires a careful consideration of the hydraulio factors incurred. However, keeping within the limits of 
good hydruulic stubllity, there are factors of design and of operation, whioh can be manipulated to give widely varlant results.

Devies (23) recommended that a tray be designed initially on the basis of the mechanloal factors. He derived the equation

$$
\begin{aligned}
\sqrt{\Delta}\left\{\Delta\left[3\left(\frac{\mu}{2}-1\right)+\frac{2}{1+\frac{1}{4} \beta^{2}}\right]\right. & \left.+3 \mu\left[d_{0}+s(\varphi-1)\right]\right\} \\
& =\frac{\mu \sqrt{\mu} \sqrt{1+\frac{1}{4} \beta^{2}} L_{H}}{2.4 C_{d} l_{1}}
\end{aligned}
$$

where $A=11$ quid grudient, difference in clear liquid levels botween inlet and outlet sides of tray, inohes.

$r=$ number of rows of caps perpendloular to llquid now.

$\beta=\left(\frac{b}{w}\right)_{d}=$ average of ratios of distanoes between oups and between risers.

$b=a 1 s$ tance between adjacent oaps in a row normal to Nlow of 11quid, Inches.

$d_{0}=$ total clear liquid depth adjacent to overflow wolr, inches

$S=$ cap skirt clearunce distance of bottom edge of oap above tray floor, Inohes $\varphi=\frac{l_{2}}{l_{1}}$ 
$l_{2}=$ total free space between risers normal to 1iquid flow, average of varlous rows, inches

$l_{1}=$ totul froe space between caps normel to 11quid How, average of varlous rows, inches

$L_{H}=$ hot ilquid quantity flowing across tray, gallons per minute et flowing oonditions $C_{d}=11$ quid gradient constant at seotion $d$.

He correlated the datu of Good and assoolates (11) by use of equation 5 .

The plot of his correlation olosely fits the data of cood, and prediots rise of liquid above the normel quiescent liquor level. These data, from experiments on 3i in. D. cups, four cups per row and six rows in a rectangular tray, with air and water, Indioated that the hydraulio gradient aoross the plate was proportional to the liquid rate and also to the vapor rate. Good does not develop any equations for the phenomena but photograph show the results. When the hydraulio gradient becomes very great, the caps at the inlet slde of the tray pass 1 ess and loss rapor and flnally bocome inoperative, allowing back flow of 11quid through the bubble cap risers. Cood likewlse showed that the hydraul10 gradient was higher for lower skirt clourance and a low soul, and that it was proportional to the number of rows of oup normal to 11quid flow, 1. O., to the bartle res- 
Istance offered by the caps and their positions on the plate.

Carey and assoolates (10) found that the slot opening leffective slot opening through which vapor is passing) increased with the rate of vapor flow. They plotted their results from reotifloation of binary mixtures as slot opening versus vapor rate on $\log -10 \mathrm{~g}$ ooordinate paper and graphically obtained slope of $2 / 3$ in the range above one oublc foot per inch of slot width. Thetr work further showed that the iepth of slot submergenoe varled directly with the vapor rate unt1l the point was reached where the liquid "cones" back from the slots.

$$
\text { 1111ams and associates (24), from experiments }
$$
on alr and water with a single bubble cap, showed that frothing above the 11quid was a direct function of the vapor velocity. Their work showed further that there was a point of vapor velocity (proportional to superfloial column velooity) at whioh the actual velocity through the slot reached a maximum. At this same point the per cent of actual slot open to vapor flow increased sharply and the pressure of vapor in the bubble cap decreased. These phenomena were olosely followed by a "ooning" back of the 11quid and consequently a reduced liquid head.

peavy and Baker (25) showed that a splashing effect due to the veloolty of the vapor was always present, and that at 10 w 11quid rates it actually decreased the 
11quid head by splashing over the outlet welr. To correct this offect they installed baffles above the outlet weir in the rapor area. These batfles prevented the splash-over and permitted the liquid to attain normal flow levels. Acoompanying this was the formation of froth extending above the top of the weir, which has little effect on the clear 11 quor helights.

The area of contact of the bubbles is of importance in that it has a drect effect on the coefficlent of mass transfer. Carey (10) predicted that a decrease in slot with would produce more and smaller bubbles and thus a greater surface contact area per unit volume. Iis concept was supported by experiments wth ethanol-water 11st111ation. L1twin (26) in other experiments roported an inproved surface contact obtalned in a cascade type oolumn. Gedies (27) in his oalculations of plate efficlenoles, makes simplifying assumptions of bubble size, surface area, and time of contact. For bubble size, he assumes perfeot spheres of a size dependent upon

$$
\begin{array}{ll}
\text { Surface tension } & \text { slot width } \\
\text { Vapor density } & \text { slot openings }
\end{array}
$$

\section{Il quid density}

There the bubble radius, $a=0.78\left[\frac{\sigma\left(h_{S}+w\right)}{P_{L}-P_{V}}\right]^{3 / 3}$

He also assumes time of contact to be =

(mean slot submergence)

$$
4 a^{0.37}
$$


These references indlcate the necessity of a study of the effect of glot height, slot width, submergence, Ilquia path, baffing, the radius of action of bubbles from the slot, turbulence, frothing etc., both on the mechanioal espects of gas-liquid contact and the kinetios of loobl efflolenoles.

It is highly probable that these factors are mutually dependent, but the prime elements cannot be ascertained as yet. Unt1l more experimental data have been obtalned, elther from the 11terature or by experimental work, the method of Geddes for determination of bubble slze, surface area, and time of contaot must suffico.

CONCENTRATTON GR DIENT

The existence of this factor in bubble cap dist1llation work has been mentioned by many investigators and studied by a few. The ooncentration gradient between liquid entering and liquid leaving the plate has been shown to be the cause of plate efflclencles above 100 per cent ( 28 ). Ilquid leaving the plate has a low-boller content much less than the average of the total 11quid on the plate und thus indicates a greater onrlohment than that predicted from the vapor-11quid equilibrium of the downcomer 11quid. Th1s is the reason for caloulated Murphree plate efficlenolos ubove 100 per cent.

Rirsohbaum (29) reported the existence of this 
faotor and determined the magnitude of its effect. He pointed out that the most desirable liquid path over the plate is a cross flow, 1.e., coross the vapor flow, with as long a path of travel and as little mixing as possible. Lewis (30) presented a mathematical expression for the difference in officiency in binary rectiflcation resulting from various degrees of mixing of plate liquids.

$$
B_{0}=\frac{\gamma-1}{\lambda-1}
$$

Where: $\gamma$ is a runetion of the concentration gradients across the plate in both 11 quid and vapor phases and is determined by a graphioal ankiysis.

$\lambda$ is a function of the slope of the operating line and the slope of the equilibrium line

$\lambda=\frac{\text { slope of equilibrium Iine }}{\text { slope of operating IIne }}$

$E_{0}=$ overall efflolency

From this he derived a relation between the overall efficiency an the number of required plates:

$$
s=\frac{\ln \lambda}{\ln \left(1+E_{0}[\lambda-1] T\right.}=\frac{\text { no actual plates }}{\text { no porfoct plates }}
$$

There: $S=$ Number of plates required in a small section of Mocabe-miele diagram divided by number of plates required in the seme section when $F_{0}=1$. 
Peary and Baker (25), observing plate efflclencies as h1gh as $120 \%$ in ethanol-water separation, measured the composition of the llquid at several points on the plate. They used an $18 \mathrm{in.}$, seven bubble oap plate and from this calculated and plotted a curre of the composition of vapor rlaing from different polnts on the plate. Gerster and associates (15) estimated the magnitude of the concentration gradlent by their "transfer unit" method of caloulation. Langion and Keyes (31) in a 5 in., I bubble cap column found plate efrlolencles as high as $220 \%$, and attributed this to the effect of the concentration gradient. 0 Connell (32) suggested an outline of a rigorous method of caloulating column performances based on several factors of whioh conoentration gradient was of prime importanoe. This method included a determinetion of liquid submergence over each bubble cap, and determination of the composition of vapor leaving the oaps near the liquid oxit weir, and a step by step calculation of vapor compositions over the plate by material balanoes based on semlemperioal relationships whioh can be experimentally determined. These relationships would be evolved rom data collected and correlated as suggested by Geddes (27). O'Connell further suggested that a correction factor for interchange of components between vapor leaving the plate ond entralned 11quid be incorporated, and that corrections for the degree of mixing and for carry over be included as well. This outline requires a 
large quant1ty of data not at present in an avallable rorm, and further requires correlations which oan be applied in mass transfer predictions. At present the mothod is unwieldy and impraoticel.

BNTREINMENT AND PLATE SPACTNG

The caloulations usually made on the entrainment phenomena assume that entrained liquid leaving with the vapor is of the same composition as that leaving in the downtake. In is is possible, but is not probably the case, 1.0. (1) the mass of 11quid on the plate has a composition higher in low boller component than that leaving in the downoomer; (2) the liquid in the upper levels of the mixture on the plate oan have lower composition in the light key component than that in lower layers; (3) the 11quid leaving with the vapor decreages in 11 ght key oomposition as it is carried aloft with the vapor.

Many investigators have shown the effect of entralnment on plate efficlency and have mads efforts to caloulate Its extent; Colbum (32) derived and presented the equation:

$$
\mathrm{E}_{\mathrm{a}}=\frac{\mathrm{R}_{\mathbf{v}}}{1+\frac{\mathrm{ex}_{\mathbf{v}}}{\mathrm{R}}}
$$

Where $\quad T_{a}=$ apparent plate effloiency $=\frac{Y n-Y(n+1)}{Y n^{*}-Y(n+1)}$ 


$$
\begin{aligned}
& F_{v}=a x y \text { repor efficienoy }=\frac{y n-y(n+1)}{y n^{*}-y(n+1)} \\
& y_{n}=\text { mole Ireotion or low boller leaving Nth plate } \\
& y^{*} n=\text { mole eraotion of low boller in equilibrium with } x_{n} \\
& Y_{n}=\text { apparent oomposition of vapor }=Y_{n}-e\left(X_{n}+1-X_{n}\right) \\
& \text { - = moles entralned 11quid per mole dry vapor. }
\end{aligned}
$$

Fe concluded that, from an eoonomioal standpoint, there is a small amount of entrainment thet oan be tolereted. The carry over lata of Peavy and Baker (25) support Colburn's (33) eindings.

Carey and associates (10) showed that the ontrainment ratio was a function of the vapor velocity, and that increased distance between plates reduced its effect by lowering the oarry over.

The entrainment was found to increase directly proportionally to the increase in vapor velocity. Plate spacings of 7 Inohes, 9 inches, and 15 inohes were used for this investigation.

$$
\text { Gerster, Koffolt a ithrow (13) produced a }
$$
oorrelation whioh suggests a logioal basio for determining optimum plate spacing from these factors. A plot of (PTU) ov vergus the vapor velocity, with the average slope of the vapor-11quid equilibrium ourve as the parameter, gave a simplo oorrelation of results at a constant vapor-11quid rat10. This mothod can be used to advantage in determining the allowable ontrainment and thus plate spacing. Using a 
glightly different approach, Souders and Brown (8) developed their equation for allowable vapor veloolty based on the quantity of entrainment that oan be tolerated.

$$
E=1-\left[\frac{(x)(1-f)+\left(\frac{e}{V}\right)(x-1)}{x-\left(\frac{x_{p}}{x_{n}}\right)\left(1-\frac{1}{V}\right)-\left(\frac{I}{V}\right)}\right]
$$

where:

$I=$ a ractor whioh represents the degree of an approach toward equilibrium between dry vapor and liquid overflow leaving the plate, and is dependant upon a large number of variables including the mochanleal design of the plate.

$V=$ total mols of mixture of vapor and entrained l1quid rising from plate to plate

- total mols of entrained liquid carrled with dry vapor from plate to plate.

VAPOR LOAD (VELOCITY)

A faotor whioh has been extenglvely studied with rospect to 1 ts effect on oolum performance is the vapor velocity. Carey and associates (10) as mentioned above, found that the slot opening (to vapor flow) increased with the rate of vapor plow. They observed thet the liquid depth on the plates was a direct funotion of vapor rate, unt11 11quid "coning" appoared. These findings were substantiated by 111 lams and assoolates (24), who found also that the 
radius of action of bubbles from the slot depended on the vapor rate. Then Souders and Brown (8) presented their equation predicting the maximum reloolty alloweble, equation (9).

Peavy and Baker (25) plotted offlolenoy versus vapor velocity for thanol-water separation, indleating a pronounced effect. Ith veloolty, the effletenoy rose rapialy to a maximum, was constent for a perlod, and then dropped off. A maximun buildup of froth was evidenced in the meximum efflolenoy range. Brown and Lockhart (9) rooommended allowable gas veloolties aocording to the equation of Souders and Brown (8)

$$
a=c\left[\rho_{\nabla}\left(\rho_{L}-\rho_{V}\right)\right]^{\frac{1}{2}}
$$

there

$$
\begin{aligned}
& G=\text { mass veloc1ty, } 1 b / h r \text { sq. ft. } \\
& \text { C - empirical fuotor, a tunction of plate } \\
& \text { spaoing and surface tenston } \\
& P_{v}=\text { density of vapor } 1 \mathrm{~b} / \mathrm{cu} \text {. } \mathrm{ft} \text {, and } \\
& P_{L}=\text { density of } 11 \text { quid } 1 \mathrm{~b} / \mathrm{cu} \text {. It. }
\end{aligned}
$$

but states that values are ossentlally constant over range from 0.4 to 1.2 times this value. The results agree with those of Peavy and Baker who reported constant efficlencles over a velocity range of 1.0 to $3 \mathrm{ft} / \mathrm{sec}$. The work of Bymen and Keyes (34) and Langion and Keyes (31) showed parallel results over range of 0.5 to 1.5 feet/seo. Stigger (6) found no effect of efflolency in vapor veloolty 
veriations between 0.7 and 1.0 reet per second.

The veloolty of rise of bubbleg through the liquid on the plate wes oulculated by oeddes (27) in his exploration of plate efflclencles. He used the equation of O'Brien and cogline (35):

$$
\nabla=\frac{4 a^{0.37}}{\mu^{0.08}}
$$

Where $a=$ the bubble radius, equivalent to a sphere, feet

$\checkmark=$ velocity of rise in feet per second

$\mu=$ viscosity of 11quid, centipolses

There is an apperent need for extended work on this fector, partioularly with the effect of slot width and column vapor veloolty on the veloolty of rise of bubbles and the consequent time of contact with the 11quid.

RETUX RATIO

The efreot of reflux ratio has generally been considered to have ilttlo or no effect on plate effiolenoy at values below one $(8,25,31,34)$. Contrary to this, the work of Gergter and assoolates (15) indicated that the number of plates equivalent to a transfer unit is a function of the reflux ratio.

An attempt wade to correlate the results or plate-to-plate kurphree efflciencies for typloal runs, as given in their data, but it was not successful because of the soattering of points. The Plate Transfer init (PTU) 
however, when plotted against $\frac{V}{I}$ gave a smooth correlation, Ind loating an increase in efflolenoy with the reflux ratio below 1 (total reflux). Inis was not the only factor of importanoe because of the other variables, but its efrect is startilngly apparent.

In strippling sections of the column, where the 11quid to vapor ratio is greater than one, this investigator found a direct relation betveen $\frac{L}{\bar{V}}$ and the plate erflolenoy, eapeolally apparent with intures having high relative volat111ty ( pages 5zto 64).

SUBMERGENCE

The effoct of this faotor on efflolency has been found to be of great importance. Most investigators have observed an increase in errlolency with increased depth of 11qu1d, and ceddes (27) attributes this to a longer time of oontuct with the vapor bubble.

Fquation (5) shows that the time of contact with the IIquid is a direct runction of the submergence because of a constant velocity of bubble rise.

Carey and assoolates (10) an later Peavy and Beker (25) obtalned data showing increased efflolencles with 11quid submergence. Good (11) showed that the submergenoe was a function of the 1 iquid rate and vapor rate and the path of Ilquid flow.

Above the 11quid is a layer of roam which aids in 
the separation process (25). Since this upper layer has a different consistancy from that of the 11quid, it is conceivable that some degree of stagnution is present. The erfect of this would be to present horlzontal layers of 11quid (and foam) having progressively lower low boller contents nearer the top. This effect has not been letermined and in raot has not been mentioned by many investigatora. It will take some rurther study to find method of determining the extent of this fuctor.

\section{I.IQUID CONCENTRATION}

There is Alsagreement among Investigators us to the effeot of the concentration of the mixture being reotifled on the efflelency of separation. Peary und Baker (25) found no effeot of conoentration on efflofency between 5 and 55 sol ethanol in ethanol-water separation. The work of carey and assoclates (10) gave parallel results, und Johnstone and Plgford (36) observed negligible erfect of concentration.

These Investigators found, howerer, that at the extremes of concentration, very high and very $10 \mathrm{w}$, there was a deorease in efflolency. Inspeotion of the work of this Investigator (pages 35 to 46 ) shows that, for mixtures of hlgh relative volatility, stripping aotion was so high that data could not be obtained in stripping sections of the column except at extremely low concentrations of the more 
volatile component. This experience indicates that eff1olenoy of soparation is lower with low conoentrations of more rolatile components, at leagt in the high relative volatility range.

On the other hand, the data of Byman and Keyes (34) for ethanol-water fraotionation and of Langdon and Keyes (31) for 1so-propunol-water indioated a marked effect of concentration on the efriofency. Their maximum efficienoy is obtalned at approximately 20 mol per cont alcohol, with gradual to sherp deorease at higher and lower conoentrations. Murnus and Taylor (37) observed a marked effect of concentration on efficiency in a packed column. An increased ooncentration was uocompanief by an increased efflcienoy. They tentativels explained this as a result of an increased wetted area, caused by decreased interfacial tension in the 11 quid with greater concentrations.

Griswold and stewart (38) obtalned data from fractionations of benzene-toluene mixtures from whloh they concluded that the efficiency of fractionation was a function of the concentration. They found deorease in efflelency of 0.6 per cent for an increase of one mol per oent benzene in the 11quid.

There is an obvious need for a careful and exaot determination of the effect of concentration on effleienoy of tractionation. The one-slot method of examination is admirably sulted for this type of study. 
VISCOSITY

The background for a study of the effect of viscosity on plate effleleney wag summarized by Delokaner and Bredrord (14), and is shown on pages 13 to 14 .

There is some controversy between investigators as to the observed effect of visoosity on efflclency. Byman and Keyes (34) obtalned date on ethanol-water separation which indloated thet the efflolenoy inoreased with increasing Viscosity. Further data, obtained by Langdon and Reyes (31), gave the same results. Where maximum viscosity prevallod, the efficiency was also at its maximum.

Contrary to this, "alter and sherwood (12) evolved a relation which indloated thet the efflolenoy was inversely proportional to the $\nabla$ iscosity to the 0.68 power, equation 12. In this the gas and 11 quid p1Im resistances were proportional to the 0.68 power of the viseosity.

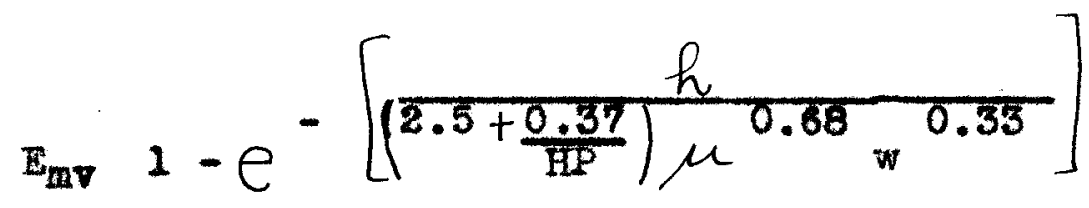

there: $B_{m v}=$ Murphree polnt vapor erficlency $-\frac{y 1-y o}{y 1-y^{2}}$

$h=11$ quid lepth from midale of slot to top of weir $\mathrm{H}=$ Henry's law coefriclent $\frac{1 \mathrm{~b} \text {. mols }}{\text { Ten. ft. (atm }}$

$P=$ slot with, inches

$\mu=v i s c o s i t y$ of 11 quid, centipolse

$w=$ slot width, lnohes 
Drlokamer and Bradford (14) developed a relation between viscosity and plate efflolonoy from data of 54 refinery fractlonating colums. They presented their correlation of overall plate efflelency as a straight line funotion of the logarlthm of the visoosity of the feed. In order to make this correlation more useful in design appliation, 0'connell (5) Introduced the effeot of relative volatility in interpreting the efflcienoy of fractionation. His correlation presented the efflofenoy as anotion of the product of visoosity and relative volatility. That this oorrelation was satisfaotorily representativo of the data is shown by this investigator in part I of this report (Figure 19 ).

This factor again presents a promising fleld for Invegtigation of effoot on plate efficienoy. Its effeot can be studied with a falr amount of accuracy in a single plate, single slot, local effloleney investigation.

RELATIVE VOLATILITY

As stated by othmer (39), "The simple operation of distillation is not related to diffusion in any important sense. It is the vaporization of volatile materlals, usually to separate one from another. Equilibrium is static, diffusion dynam10." It seans that eren in this stultifled outlook the separation which theoretically oan be obtained by distillation is ultimately influenced by the relative volatility of the components involved. The resistanos to 
diffusion must enter to prevent attainment of this theoretical sepsration. O'Connell (5) and this investigator have shown, howerer, that the relative rolatility of the components also affects the degree of attainment of theoretical separation (100 per cent efficienoy). The o'Connell correlation presents efficiency as a function of the relative volatility and viscosity.

This effect may be explained as follows: Since there is Ifttie reason to suppose a change in the diffusional resistance coefflclent with ohanges in relative volatility, 1t may be assumed that no change occurs. It may also be assumed that the time for diffusion of components to and from the vapor bubble will remain substantlally the same regardless of the volatility. In a given time of contact given number of moles of materlal are trangferred and a definite separation is obtained. Now, w1th greater relat1ve volatil1ty the theoretioal separation obtainable 18 greater, and the ratio of actual separation to theoretical (efflolenoy) is lower. Then if the relative volatillty is lover, the possible separation less and the ratio of the actual separation (whioh has remalned substantially unchanged) to the theoretical, is greater.

The data do not ind loate that this offoct is wholly reallzed, but the correlation of o'connell supports the conclusion. That the effect is not es pronounced as the explanation Indeates is probably because of the widely 
dffering rolatility of the components as they come in contact.

In the work of Gerster and assoolates (15), it was polnted out that the slope of the equilibrium ourve had a direot bearing on the actual number of plates requirea per transfer unit. It the number of trangfer units is equal to or has a drect relation to the number of theoretical plates required, then the plate offelency mag also be consldered a funotion of the slope of the equilibrium curve, and hence the relative rolatility, which is a mathematical representation of the slope.

MSS TR WSER CONCEPT

The physical meohantam by which equilibrium conditions are approached is neossarily that of interdifrusion between the Ilquid and vapor phases. The method of molecular transfer between phases has long been assumed to oocur across an interface (40) composed of a film of vapor In contact with a film of the 11quid. In distillation work the net condensation of the less rolatile component from the vapor within the interface and the net evaporation of the more volatile component within the interface takes place almost instentaneously.

There 1s, however, an opposition to the approach of molecules to the interface represented by the resistanoes presented by the 11quid and rapor flims. The net movement 
of the more volatile molecules to the interface through the Iiquid film and arter vaporization through the gas film into the bubble is effected by the resistance of the respective fims and to the ariving force which oauses transfer. This ariving force is a direct funotion of the concentration difrerences across the f1lms. The less volatile component is moving in a direction opposite to that of the more volatile and as the less volat1le moleoules oondense at the interface they give up the heat required to evaporate a oorresponding number of molecules of the more volatile component. It appears, therefore, that pure diffusion oharacteristios must be somewhat moilfied by the necessity of heet transfer.

These phenomena progress as a funotion of time and do not allow equilibrium to be attained in the short period of contact experienced by a bubble rising through a shallow tray of 11 quid.

PIIU RESISTNCE

In the upplication of this factor to the determination of fractionation efficlenoy, it will be necessary to follow a method outlined by Gedjes (27) an 1 expanded by the deta of other 1nvestigators. The data on film resistance in reotification are so meager in bubble cap work as to present serlous diffloulties. It w111 therefore be necessaxy to explore the data for other means of estimation and to apply methods to adept these date to bubble cep work. 
Geddes initiated this procedure and laid a valuablo base from whloh to projeot the investigetion.

Othmer (39) made attempts to measure the driving forces present in the actual f1lm but was not sucoessful because of the microscoplc thickness of that film.

Other empirical and semi theoretioal methods to develop a relation between film resiatances and other variables heve been attempted as follows: walter and Sherwood (12) empirically itted an equation to their data for bubble cap absorption. Their equation has been reported under "V1seosity".

Peck and lagner (41) present a method for the dem termination of the relative resistance presented by 11 quid and vapor in distillation. Since their graphioal analysis requires an operating 11ne with a slope of one, their method of oeloulation conflnes their work to operations of total reflux.

Their results ind lcate thet the resistance of the gas flin is 50 per cent in bubble plate columns and 100 per cent in wetted well towers. The data presented for rectifloation of Methanol-water, and 1sopropanol-water in a wetted wall tower check those obtalned by Johnstone and P1gford (36) for distillation in a wetted wall colunn. There is no reason why different systems should have identleal $\frac{K_{g}}{K_{l}}$ ratios, and the results should be accepted with caution. 
Johnstone and P1gford (36) tried to allow in their correlation for the turbulence in the ges whloh is in contact vith the 11quid and for the wave motion and laminar flow in the 11quid phase. With this purpose in mind they correlated their results on fractionation of four different binary systems on the basls of the average Reynolds number of the vapor strean relative to the moring interface. Then oorrelated in this manner the data fell between the equations of Von Karman and Sherwood (42) and G1111land and Sherwood (43) and the equation of ch11ton and Colburn (44) for the diffusional phenomena in absorption work. is plot of

$$
\frac{\text { (HTU) ov }\left(\frac{\mu}{\rho D}\right)^{2 / 3}}{d}
$$

Is found to be a straight ine runction of the $10 \mathrm{~g}$. of the Reynolds number. (Where $d$ is the diameter of the column.) Taylor end Furnas (37) utilized the equation

$$
k_{L} a=\frac{k_{L}^{a}}{I+\frac{k_{L^{a}}}{m_{k_{G}}^{a}}}
$$

In an attempt to separate the resistances of the two films in packed tower distillation. Their results were not conclusire but indlocted that the resistanoe resided primarily in the 11quid film. This result is contrary to that of other investigators. 
Surowlec and Furnas (45) used the same tower as used by Taylor (37) but without packing. For determining the resistance in the gas filn they used the equation of ch11ton and Colburn (16):

$$
(\text { HTU })_{G}=10.9 \cdot \mathrm{a}\left(\frac{\mathrm{dv} \rho}{\mu}\right)_{G}^{m} \cdot\left(\frac{\mu}{p D}\right)_{G}^{n}
$$

and derfved exponents from the deta of G1111land and sherwood (43), producing $m=0.17, n=0.56$, where $a$ is the dameter of the column in feet. They used for the liquid rilm their own derired equation analagous to Nusselt's work and adapted to mass transfer:

$$
\left.k_{I}=\frac{B^{\prime}}{\left(\frac{D_{L} \rho_{L}{ }^{5 / 3} q^{1 / 3} \Gamma^{1 / 6}}{3^{4 / 3} H^{2}} \mu_{I}^{1 / 3}\right.}\right)^{2 / 3}
$$

where:

$$
\begin{aligned}
B^{\prime}= & \text { o constent } \\
B= & \text { accoleretion due to grevity, } \mathrm{ft} /(\mathrm{hr})^{2} \\
T= & \text { peripheral liquid rate, } \\
& \text { lb/hr ft of wetted perimeter } \\
D= & \text { diffusivity in square } \mathrm{ft} / \mathrm{hr} . \\
H= & \text { helght of column, feet. }
\end{aligned}
$$

Using this equation they determined that the resistanco was largely in the gas phase as compared with the reverse results of Taylor (37). They recono1le this apparent 
disagreement by use of equation 14 whioh indieates that the gas film resistanoe is inversely proportional to the 1.17 power of the diameter of a given ofroular condult. Thus the effective dlameter of the packed tower is lessened by the prosence of packing. These assumptions and rationalizations must also be acoepted only as opinions in variance.

colburn (46), in a study of difrustonal processes, recognizes the 2-film resistence conoept and presents an analysis using an HTO method of calculation. The overall HTU is equal to the gas rilm HIU plus the (product of the Ilquor film HTV and the ratio of the equilibrium curve to the slope of the operating ine). This method has been applied to ubsorption oeloulations but w1ll necessitate careful revision for use on plate distillation work. This procedure was followed to a great extent by Geddes (27) in application to his work.

MASS TRNS WER COEFPICIENT

The work of Walter and Sherwood (12) Indlosted a relation botweon the transfer ooefflolent and the ratio of the slot veloolty to 1 ts area. Thus as the ratio $\frac{V}{A}$ increased, the coefflolent of mass transfor increased proportionately. The magnitude of the inorease is Iimitad by the waximun value whioh $\frac{\nabla}{2}$ can reach because of hydraul 10 considerations $(23,24)$. The data obtalned on the effect of this factor were used in the evolution of equation $1 z$. 
Litwin (26) observed a material increase in the mass transfer coefflolent when an inoreased surface area is exposed to the 11quid in the oascade type still. The turbulence affected by the violent action is also a probable Influeneing factor. The lnorease in the value of the liquid flin coefficlent observed by Taylor and Furnace (37) is attributed to an increased area caused by an inoreased wetting of paoking.

There is needed much explanation of these phenomena. A odreful and planned research should bring into rellef some of the factors whloh affect the mass transfer coefflolent in bubble plate dist111ation work. The mass trensfer coeffiolent is probably the most important part of this investigution, for it determines to what degree the theoretioal separtion of the operation will be obtained. A determination of the governing ractors may show a way for new design whloh w1ll naterially increase the effelenoy now obtalnable. 
DESION OF EXPERTMNTAT EQUIPUENT 
From an analysis of the foregolng survey of the 11terature, it is evident that much is to be desired in the intelligent application of the material avallable for predicting operating charaoteristics in design of distillation equipment. In order to form a conclse, understandable, and logloal pattern from which an explanation of the exact effeots of the varlous factors can be evolved, it is desirable to approach the problem rrom the standpoint of the basio relations of dist1liation. It has been suggested that such busic relations be evolved from experinental observation of operations on a single plate, single slot, bubble type rectifler. A design for such an apparatus was developed and is explained in the following paragraphs.

Because of the fundamental nature of the invest1gation of factors affecting plate efflolencles it became evident that speolal equipment would be necessary for the collection of experimental data. hocordingly, from suggestions evolving from alscussions of the problem, models of two possible types of equipment were construoted of corrugated cardboard. Bach of these models, figures 20 and 21 , has a tray bounded by a vertioal wall which separates the I1quid and vapor. In the lower section of this well is a slot through which vapor is allowed to pass. Ilquid is to flow from the downcomer into the horizontal tray on one side of the vapor-1lquid separating wall, past the slot, and over the level-control weir at the outlet end of the 


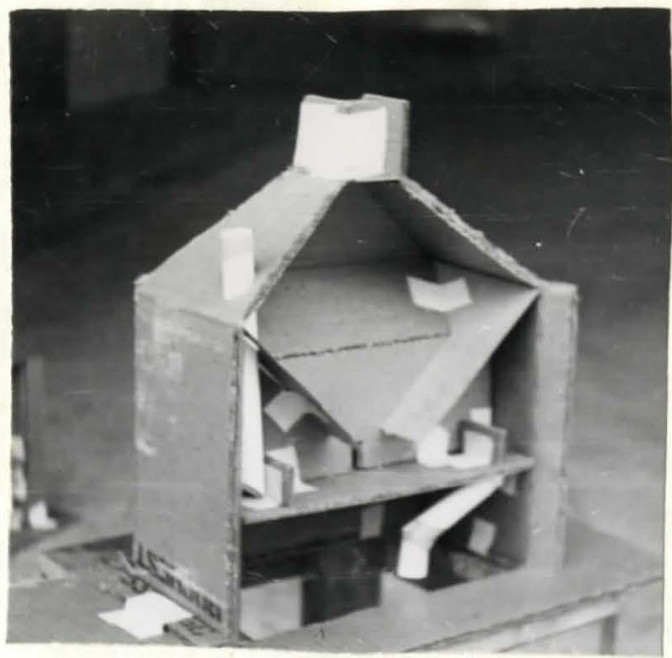

Figure 20 One plate,

Single slot Rectifier Number 1

Tigure 21 One Plate

Single slot Rectifier Number 2
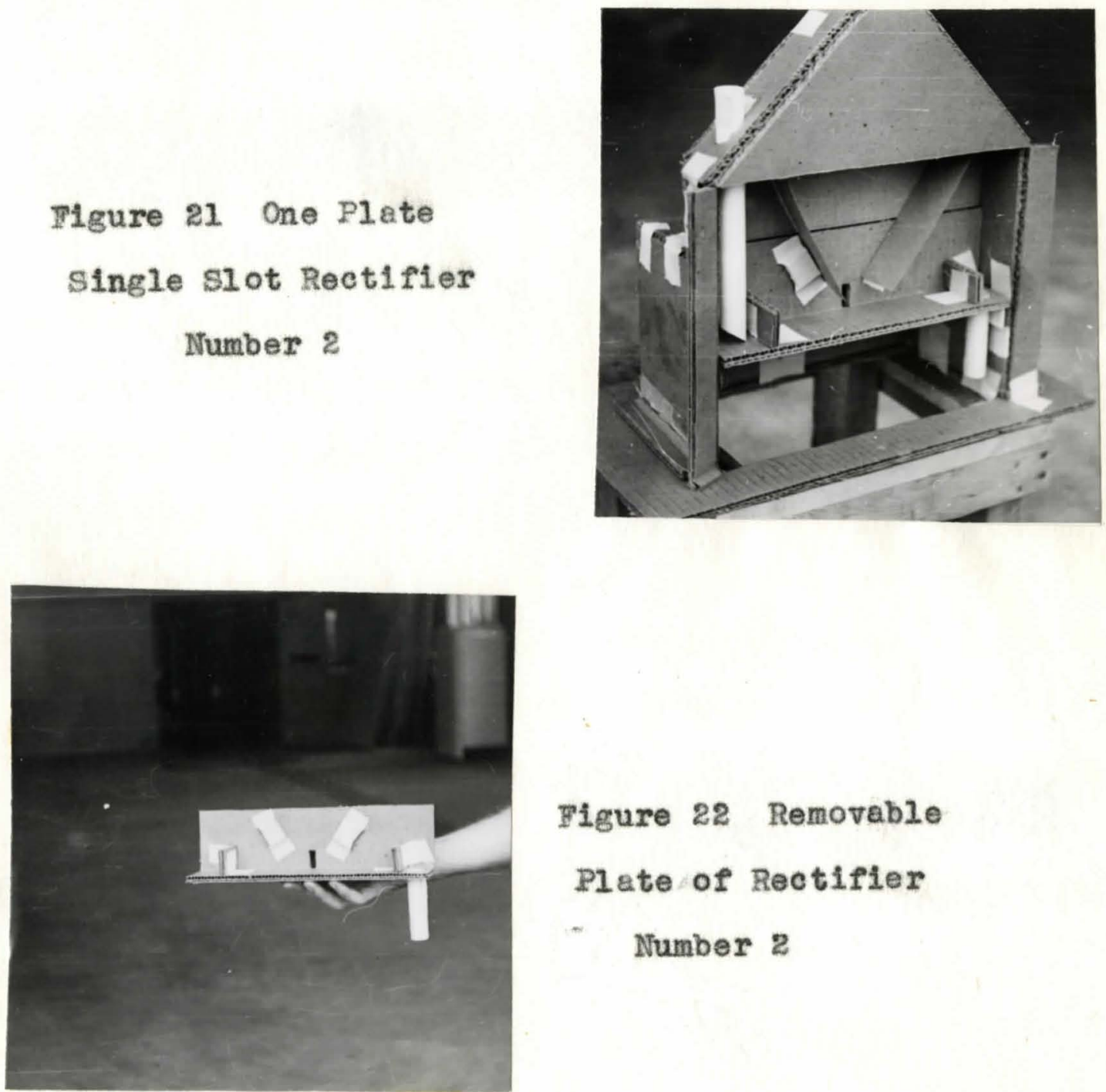

Figure 22 Removable

Plate of Rectifier Number 2 
tray. Vapor from the calandris is to flow through the glot and bubble through the 1iquid. It is to pass up from the surface and be colleoted in the uptake for subsequent condensing.

Above the surface of the 11quid on the tray are two baffles whose purpose is to confine the vapor from the slot so that it does not oome in contact with a 11quid surpace larger then that normelly existing in a bubble plate column. In this way the erfect of vepor and liquid contact at the 11 quid surface will more nearly approximate that In Industrlally designed trays. Inolusion of beftles will also eliminate the added epfect of this surface contact and should make analysis of the rosulting data simpler. It is planned to olose the front of the experimental plate with a clear glass plate. Th1s plate w11l be sealed to the column with a ohemically reslstant sponge rubber or other material, and olamped in place.

Ilquid level will be controlled by an ajustable clip on the outlet we1r. Slot dimensions oan be changed by inserting different plates, Flgure 22. The baffles oan be ad fusted to conform to ohanges in 11 quid level and to frothIng charuoteristlos. 
DISCUSSION 
The need for concentrated research on several of the faotors which affeot plate offlolenoles is quite apparent. On the other hand, the determination of the effect of some factors has been felriy well oompleted.

The effoot of varlation in hydraulio factors is In some cases well establishod, but in other respects needs further study. For instance the effect of the hydraul10 gradient, the bubble action, eto. on the degree of mixing, and consequentiy the concentration gradient, has not been determined. In addition to this it seems desirabie to make a study of these factors for determination of a vertioal conoentration gradient oxtending into the roum above the 11quid.

The exact effect of entrainment and of other fuotors on entrainment has not been determined from the standpoint of the nature of the mixture of entruined 11quid and vapor.

There is a definite need for a study of the effeot of reflux ratio, both in rectifler and in stripper operations. A study of the effect of submergence on the mass transfer coefflolents and on the effloleney is also desired. The widely disputed effect of ooncentration of the 11quid calls for an especially intense study. Of ulmost us great Importance is the disputed effect of the viscosity of liquid on the plate.

A method of physioal attaok on the evaluation of mass transfer ractors has not as yet been formulated. A 
mathematicul approach is indioated, however, in order to prediot the results to be obtained by experimentation. The one-plate, single-slot rectifier proposed for an experimental investigation of effocts of operating varlables should be well sulted to the nature of the work involved. It appears that suoh en investigation should prooeed along the IInes suggested by Geddes, In his paper presented on the factors which offect $100 a 1$ efflolenoles on bubble plates. The information and equations obtained from the Iiterature can be analyzed and adapted for use with bubbling phenomena. One faotor of considerable importanoe is the effect of turbulence in the bubble. This effect will be refleoted by the magnitude of the transfor coefficlents. It is conoelvable that in a serles of controlled exper1ments, Imultaneous equations may be developed and some of the non-measurable quantities thereby calculated. 
SUMMARX 
A survey of the 11terature has boen made to determine to what extent the data on faotors affecting plate efflolencles can be oorrelated. Varlables studied were, hydraulio relationships, liquid submergence, ontrainment and plate spaing, concentration gradients across the plate, the average concentration of components in the 11quid, vapor veloolty and $v$ apor-11quid ratio, average viscosity of the 11quid, relative rolatility of components, and the basto mass transfor relationships inrolred.

Consideration of the results of the surrey led to the design of an experimental unit whloh oan be used for obtaining basto data for prediction of $100 a 1$ effiolenoles from o orefully controlled mantpulation of construotion varlables and operating varlables and procisely measured physiogl characteristios. Photographs of models of the unlt so degigned have been presented. 
III. PROPERTIES OF LAMINATRD WOOD OLUE IINTS

INTRODUCTION 
The use of wood as aterial of construotion has been known to man as long as the art of construction 1 trelf has been practioed. There are several reasons for its wide use, among which are its inexpensiveness end avallability, Its versatility and adaptebllity, and its durability and resistance to weathering conditions. As a consequence of the high usability of wood, and its plentifulness in the pest, there has been a great waste of valuable raw materials because of the haste of man to obtain the oholce seotions of the tree. In reoent years constant offorts have been made to ut1lize more economieally the totel wood content of the tree, to improve the properties of the products made from wood, and to find new uses for these improved wood products. One of the most valuable uses of wood is in the manufacture of laminated products. These are manufactured by the bonding of layers of wood by a sultable edhesive. Laminated wood has been made in many forms and shapes. It has been made in varying degrees of strength from thin, threoply plywoods, one elthth of an lnch thlok, to mult1-ply beams of greater than a root thiok. Under sultable condtions it can be formed lnto various and sundry ourved shapes.

The use of laminated white oak reneers as a materlal for barrel staves was recently conoelved and has beon started commercialiy. These laminated mombers are designed to be used as a substitute for solld oak stares in the menufacture of barrels for the age ing of whlskey. 
A factor whioh might linlt the economical use of barrels, made by the above methot, for the ageing of whiskey, 1s the variation in "outage". The "outage", or 10ss of 11quid through the walls of the barrel, was found under certaln conditions to be over twice that of the los from a barrel construoted from solid oak staves. Since this faotor was undesirable and placed a limit on the useability of the product, It was decided to make an investigation of the problem to obtain more uniformly desirable produot. Extensive researoh had produced a bonding glue whloh was not harmerl to the contents of a whiskey barrel. Since it was desired to continue the use of this adhesive, Penacolite G-1124, this investigation is directed toward the improvement of the physical properties of the glue ine formed botween wood voneors. 
HISTORICAL. 
The propertles of wood have been greatly enhanoed by developing bonding glues and by their intelligent epplication. One of the most Important adrances in wood utilizat1on as atructural meterial can be credited to the 1mprovement in glues and gluing technlques.

It is importent that the glue bond of laminated structures be as strong as the wood which is being held together throughout the service ilfe of the materiti (49). A number of glues have been developed which fulfill these conditions under adverse oonditions (50). Phenol-formaldehyde and urea-formaldehyde resins have come into use. The resorolnol-formaldehyde resin glues are rapidy coming to the fore $(51,52)$.

One of the resorcinol-formaldehyde resins, Penuool1te G-1124 (53), was chosen for the fabrication of barrel stares beckuse of its favorable behaviour when subjected to strenuous extraction tests (48). Under the established fabrication conditions, however, the product was not completely satisfactory from the atandpoint of 1ts permeability to wator.

The permeablitty of wood to the flow of water was studied by Irlokson and assoclates (55). They found that the rate of flow of water through wood decreased with oontinued flow and approached equilibrium after sefinite perlod. Stamm and associates (56) studied the diffusion of water vapor and 11quid through plywood speoimens. Their 
Investigation remulted in the conolusion that if the veneers are pre-1m-pregnated with resin thet there is a reduction In permeability of as groat as 90 per oent.

It was suggested that the structure of the glue Iine itself be investigated in order to determine the reasons for the high permeability found in Penacolite-bonied white osk reneors.

Demarco and smith (57) presented a method for the determination of the penetration of resin from the glue Ines into the surface of veneers by oolor indioators. Farrow and assoolates (58) developed a more praotioal method in whioh the wood reneer is remored completely by digestion In an aold bath, loaving the glue film untouobed for visual Inspeotion. 
THEORETICAL 
The atructure of wood has been found to be micellular. The oell alze and density, the pit membranes and grain orientation vary with the type of wood and with its climatic environment (47). The normal trunk is awollon when green, with dead heartwood at its conter and ootive fibrous cells in the outer part (59). The seasoning of wood removes this molsture and ohanges radically the physloal properties of the seasoned product. The dry, oured wood adsorbs water, and is so swelled by it that 1ts structure expands, ellowing more surface for continued alsorption of water (47). Wood has been known to adsorb as much as 300 per oent of its dry weight.

Stamm (60) showed that molsture is oarried through wood in three ways: (a) as a liquid, above the fiber saturation point, (b) as bound water within the cell walls, (o) as vapor, due to humldity gradients.

In resin-bonded reneers this flow of molsture is impeded to a greater or lesser extent by the presence of glue IInes as barriers. At first glance it might seem that a resin, ingoluble in water, and forming continuous sheet at right angles with the flow of water, would present an Impenetrable barrior to the flow. That this is not the case, howerer, is the reason for this investigation. 
EXPERTAENTAL 
STRUCTURE OF GLUE TIIN

In an investigation of th1s type it was found

destrable to make prelininary studies of the physloul characteristios of the glue bond whloh is fomed between veneers

In the fabrioation of laminated seotions. Because the most

rellable and the most emphat10 method of presenting evidence

1s by vigible meana it was deolded to use the mothod of

Farrow (58) for vigual examination of glue ine struoture.

The procedure is given by Ferrow in the following:

"The pregent standard praotioe is to suspend the test speolmen in hot ohromic acla solution ( 100 grams of chromlo acid in $100 \mathrm{cc}$. of water) with about $2.5 \mathrm{~cm}$. (1 inoh) Immersed. The remainder of the specimen forms the support. Digestion is carried on at 80 to $85 \mathrm{deg}$. C. for about 20 minutes, whloh $1 \mathrm{~s}$ oufflelent to expose completely the glue 1 ines in 3-ply 1/16-inch birch veneers. After careful digestion, thorough washing with hot water 18 necessary to remove the ohromlo aold and the carmel-1 ke produots of oxidation, which, if present, obsoure glue line detall. The spocimen is then rinsed with soetone and allowed to dry. Though complete removul of this sludge is very diffioult in the case of flber casts, normal washing and drying are rapid and permit immediat exemination of the resin."

Two-ply seotions of laminated rotary out white oak veneer $3 / 16$ inch thlok were rabrioated in a heated press at 240 deg. $T$. and 150 pounds per square Inch pressure for elght minutes. The adhesive was Ponacoltte 01124 in fourto-one proportions of the prepared resoroinol resin and of formaldehyde eatalyst, as recommended by the manuracturer. Speoimens were out from these sections and digested in ohronic acla by the method of Farrow.

After nine hours digestion in 50 per oent chromio 
acid at $85 \mathrm{deg}$. C. It booame apparent that no more then 50 per cent of the wood layers would be removed in this run. The hot acld attacked the outer layers of soft spring wood and removed them quiokly; the hard summer wood wes so slowly reacted that it was not remored even with nine hours digestion. The specimen was removed and placed in a bath of Fresh 50 per cont ohromic acld at $85 \mathrm{deg}$. C. Thls procodure caused all remalning wood to be removed from the glue flim in less than one hour.

As a variation of the procedure a solution of ohromic acld made up from fresh ohromium trioxide in ratio by wolght of 40 parts to 60 parts of water. This solution was placed in a contriner, a new specimen suspended in the bath as before, and total rerlux condenser attached to the container. The beth was then heated to the bolling point and maintained at this temperature until all wood veneer was removed from tho glue film. The time required for this and subsequent runs raried from 40 to 90 minutos. All glue film speolmens from the digested seotions showed similar construction. There were long thin projections of resin, lying in planos parallel to the grain of the wood. These profeotions are indloation of the penetration of the edhesire into the oraoks inherent in rotary out reneer. In the flim itself wore small, long1tudinal perforations indlcative of "starved" spots in the otherwise continuous rilm. 
Quantitative data are not practioal by this method except as to the depth of penetration of the adhesive. The projections showed that this depth varled from very slight penetration to depths oqualing the thlokness of the veneer 1tself. 
PENETRATION OF GLUE FIIU

At this stage of the Invegtigation it became desirable to make a moro nearly exact eraluation or penetration of the adhesive into the rotary out whito oak voneers beling used in fabrication of laminated seotions. Accordingly, another method of visual analysis of penetration was adopted. Th1s method involred the use of a oarpenter's plane for removing ouccessive layers of veneer and the est1mation, by visual inspection, of the area occupled by the adhesive in these suocessive lagers. Thus a quantitative estimation of the degree of penetration oould be obtained from knowledge of the adhesive present in adjacant planes of the veneer parallel to the glue 11ne.

Specimens for investigation by planing tests were out fron flve-ply, laminated staves fabrioatod at Camblo Brothors' plant in Loulsville. These gpecimens were out ten Inohes long and one inoh wide from staves whioh were threo foet long and one foot wide, having a radus of ourvature of 1.5 feet. They were out from various positions in different staves as is shown in Table XII.

Results of planing tests are shown by the ourve or Pigure 23. Though the utilization of a logarithmio plot for the representation of glue ooncentration at different plenes exaggerates to some extent the accuracy of the estimation of low absolute glue concentrations, it enables an expression whioh most nearly represents aotual conditions. 


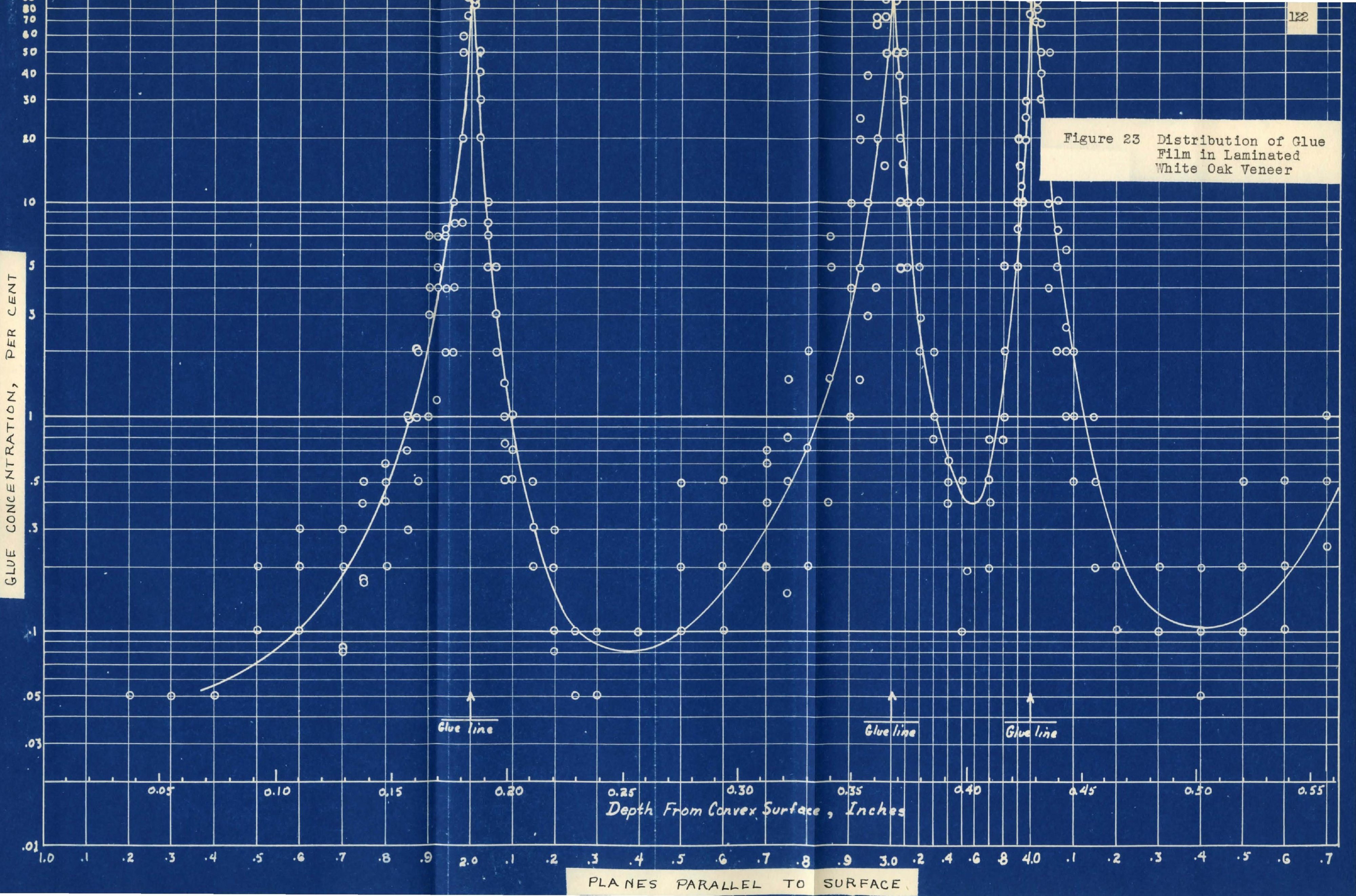


Furthermore this method of presentation produces a more easily interpreted relation. The laminated sections were divided into planes equidistent from one another, and are so represented in Flgure 24 . Veneers were numbered one to flve, starting at the convex surface. Fach reneer was equally divided into ten parallel sections which were further divided into ten sections each, all such sections being designated in figure 23 by their decimal equivalents. The center veneer, whioh $181 / 16$ inch thick as oompared to the $3 / 16$ inch thickness of the other veneers, is designated on the rigure in 11ke manner.

Datu, represented by points on the plot, are the result of investigation of six specimens, each from a different stave (Table XII). Analysis of the plot shows that penetration of glue into the surface is small in quantity, but that the depth of penetration is extensive. From inspection of the data obtuined on elther side of the first glue line it is evident that glue penetration into the concave, open face of the first veneer was slightly greater than that into the smooth convex surface of the second veneer. In Inner veneers penetration was slightly greater than that oridenced in those at the surface. The conter reneer, which has 1 ts grain at right angles to that of the other veneers showed greater penetration into 1 ts oonvex surface than into its conoave surface.

In the production of rotary cut veneer the outting 
TABLE XII. ORAACTERISTICS OF PLANING SPEC IMENS

Speoimen

1

2

3

4

s

6
Position in Stavo

Center

side at center

side at center

Center at ond

Center at end

Conter

blade whioh remores the sheet from the rotating $10 \mathrm{~g}$ oausea a roughened and oracked surface on the concare side of the produet. This is the surface which was more easily penetrated by adhesive (Figure 23). Th1s was a logioal development whioh has thus boen substantiated by observation. On the other hand, the thin cross-grained veneer in the center, had its convex side in tension and its conoave side In compression. One would expeot a greater penetration to occur in the side which was stretched than in the other. That this was the oase was substantlated by the duta and is shown In Figure 23.

The original data indloated that greater penetration of adhestre is experienced in veneer sections at the center of the barrel stave than at outer edges. Th1s variation may be due to slightly different curing conditions oxlating in different perts of the stave, to heat losses at 
the edges, and to the tendency of the resin to be squeezed out the edges or the stave while being pressed. These original data were consldered too voluminous to be inoluded in this work in tebular form, but have been shown graph10ally in Isure 24 
RESIST WrE TO LIQUID DIFPUSION

Having determined the general nature of the physioal structure of the resin film existing in glued white oak laminates it beoame desirable to make quant1tative determination of the rate of diffusion of 11 quid water through a number of epecimens. In order to determine the relative realstances to alfrusion presented by specimens fabricated unjer different conditions, it was planned to carry out alfrusion measurements under similar conditions for each apecimen.

An experinental unit was designed and constructed a shown in Migure 24 for measurement of aiffusion of a I1quid through flat seotion of laminated veneer into the atmosphere. The Ilquid pressure exerted agalnst the surrace of the specimen was flxed by the helghth of 11quid in the unit above the plane of the specimen.

Procedure.

In preparation for a test of glue flim alfrusional resistance, a speoimen was fabrloated under a set of cond1tions as 18 shown in Table XIII. For runs number one and two, the speoimen was placed in the difrusion unit head and sealed by applioation of a glyceryl phthelate resin. This method proved unsatisfactory because the alr-dming resin took an excessively long arying period. For subsequent runs the speolnen was edge sealed with three or more coats of 


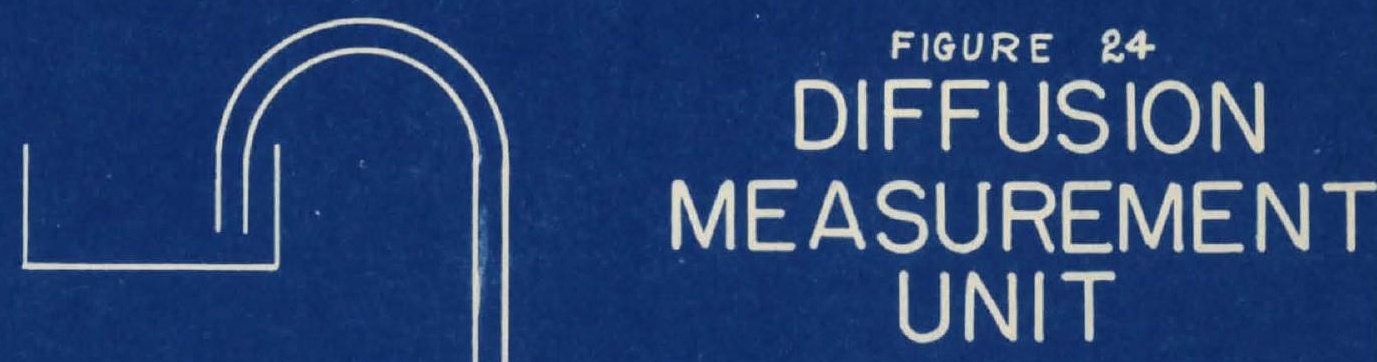

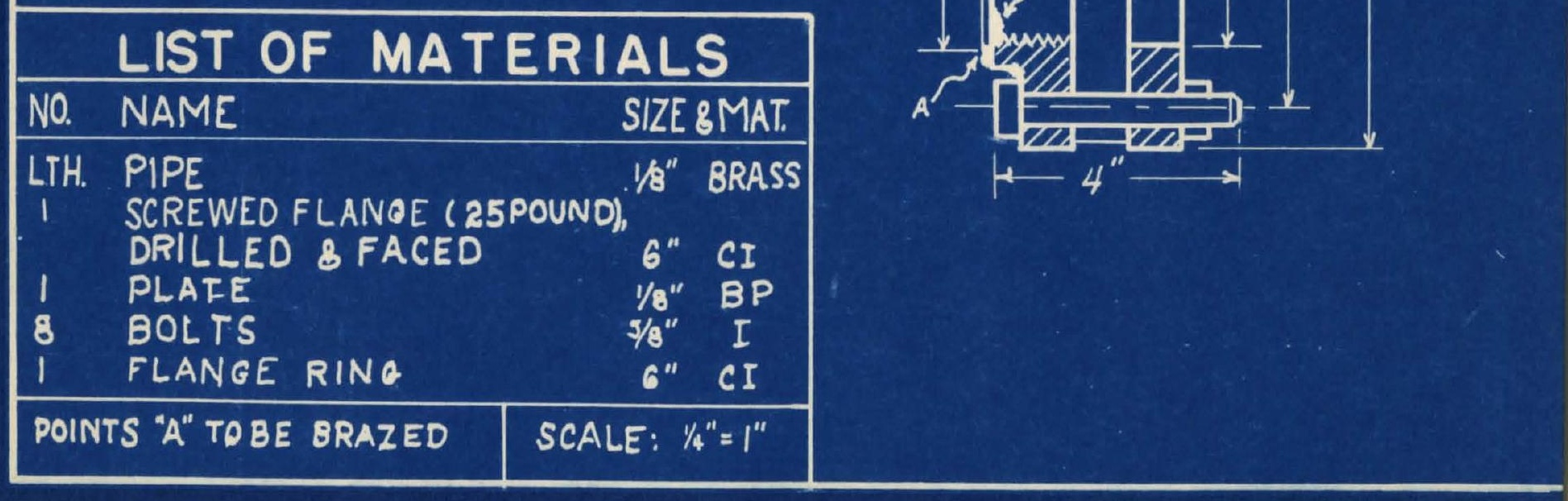


TABLE XIII. DIFYOSION TEST SPEC RMENS

\begin{tabular}{|c|c|c|c|c|c|}
\hline Specimen & Precure & Curing & Yond 1t lons & & Wood Rays \\
\hline Number & $\begin{array}{l}\text { T1mo } \\
\text { Hours } \\
\end{array}$ & $\begin{array}{c}\text { Pressure } \\
\text { psi } \\
\end{array}$ & $\begin{array}{l}\text { Tomperaturo } \\
\text { Degreos T. }\end{array}$ & $\begin{array}{l}\text { Time } \\
\text { Min. }\end{array}$ & per Inch \\
\hline 1 & 0 & 150 & 240 & 8 & \\
\hline 2 & 0 & 50 & 250 & 8 & \\
\hline 3 & 0 & 50 & 250 & 8 & \\
\hline 4 & 0 & 50 & 250 & 8 & \\
\hline 5 & 0 & 50 & 250 & 8 & \\
\hline 6 & 24 & 50 & 250 & 8 & \\
\hline 7 & 0 & 50 & 250 & 8 & 12.5 \\
\hline 8 & 0 & 50 & $\mathbf{2 5 0}$ & 8 & 14.5 \\
\hline
\end{tabular}


the glyceryl phthalate resin with a low-temperature 1180 deg. P.) cure between each applieation. To prevent subsequent dimensionel ohanges in the specimen ufter being placed in the unit and whlle it was belng saturated with water, the specimen was next Immersed in water for a presoak perlod of approximately 24 hours. The speoimen was then pleced between the rlanges of the diftusion unit head and sealed with a coarse pararin-impregnated thread. The difrusion unit was then assembled as shown in plgure 24 and fllled with water; ull ulf was vented from the system and the syphon started. The volume of llquid was then brought up to the design level. Flow messurements were made by observation of the amount of decrease in the liquid content of the system during a definite time interval. At the end of each time interval (usually one day pertods) the volume of Ilquid in the unit was inoreased to its inftial lerel by almission of a measured quantity of water from the burrette. This measured quantity (arter temperature correotions) represented the flow of llquid through the exposed surface of the speolmen during the elapsed time interval. such data were reoorded at the ond of each interval. After sufficlently congtant flow was reached, the run was considored complete and the data were used in flow rate caloulat1ons.

Results were calculated by setting up a welght material balance across the system, lncluding correotlons 
for changes in density of the water loausing erroneous volumetrio readings) with temporature variation. The followIng equation was ut1lized:

$$
\text { 浱 }
$$

Where

$W_{1}$ is the welght of water placed in the unit Initially

$w_{2}$ is the welght of water added at time of readIng to replenish the total contents to the In1tial rolume

$W_{2}$ is the welght of water in the unit after $w_{2}$ has been added

$w_{D}$ is the weight of water diffused through the speoimen during the elapsed time interval

Prom this equation the average rate of iffusion on an inoremental basis was oaloulated by the followingrelation:

$$
D_{1}=\frac{w_{D}}{\left(t_{z}-t_{1}\right)(A)}
$$

Where

$$
\begin{aligned}
D_{1}= & \text { Average diffusion rate for the interval } \\
& t_{1} \text { to } t_{2} \text {, pounds per hour per square foot } \\
t_{1}= & \text { time of reading } \\
t t_{8}= & \text { time of reading at ond of first interval, } \\
& \left(t_{2}-t_{1}\right) \text { is the period over whioh diffusion } \\
& w_{D} \text { occurred, hours } \\
A= & \text { oross sectional area of speoimen through } \\
& \text { which difrusion ocourred, square feet. }
\end{aligned}
$$


DATA AND RESULTS

Sach speolmen subjeoted to difrusion tests was fabricated under the condition isted in Table XIII, and was out from a two-ply seotion of $3 / 16$ inoh wh1te oak veneer, laminated with grains parallel. The adhesive used oxolusively wa Penacolite 0-1124 in a rat1o of four parts or resin to one part of formaldehyde catulyst. Each speo1men was flat and ootagonally shaped, measuring seren inches across.

Regults of the difrusion tests were plotted as a function of time. Flgure 25 shows a typleal ourve for the accumulative flow of water throughout the duration of the run. Th1s plot represents the date obtained from tests of speoimen Number 5. The slope of the straight portion of the ourve represents the average rate of flow in pounds per squere foot per hour for the duration of the run in question. F1gure 26 shows accumulative results of all runs plotted In the same manner as were the data for specimen Number 5 . The data are now shown by individual points on the plot to avold any unnecessary con rusion.

Figure 27 is the result of a plot of incremental flow rates determined at the time of each reading. These data elso represent tests on specimen Number 5 and show the relative deviation of each result from the average rate of flow. Shown in Pigure 28 are the average rates of flow for all specimens tested. Here again the individual data 
are not shown in order to arold confusion.

Three runs were made with speolmen number one whloh was rabrioatod under conditions givon in Table XIII. The first two of these rung utilized a three foot heat of water. The method of flow measurement for these first two runs was not as aocurate as that with subsequent runs booause of inftial diffieulties in setting up the epparatus. Furthermore the amount of iffusion under the three foot pressure head was too small to magnify any experimental crrors. Therefore, the date were inoonsistent, and the reported flow rates of .00009 and .00035 pounds per square foot per hour should be congldered ag approximate. The third run with spooinen number one was cerried out under a 13-foot head of water and the standardized method of measurement using the apparstus as shown in Figure 24. The average flow rate for this run was 0.00078 ( Migure 26 ).

Also represented in 19 gures 25 and 26 are the results for subsequent speolmens whose ouring conditions are shown in Table XIII. Average results of all difrusion tests are rocorded in Table XIV.

The consistenoy of the data obtained for eaoh run is excellent in viow of the several factors whioh might cause deviation. (a) Although the oaloulations inoluded the effect of temperature variation on the volume of fluid In the un1t, they did not compensate for the variation in the rolumetric oapaolty of the unit itself with temperature 


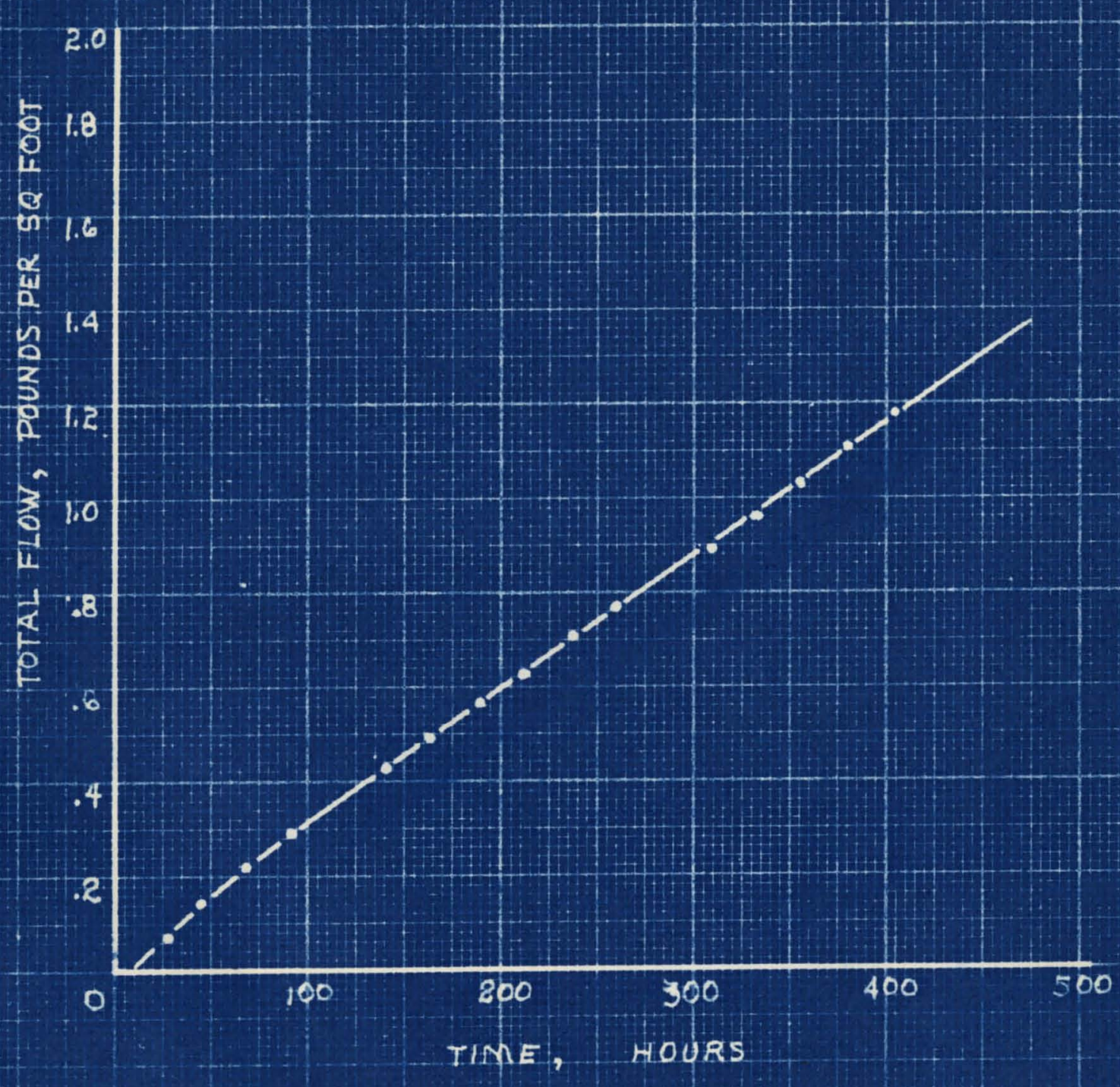

FIGURE $\approx 5$

ACCUMULATIVE FLOW SPECIMEN NO. 5 


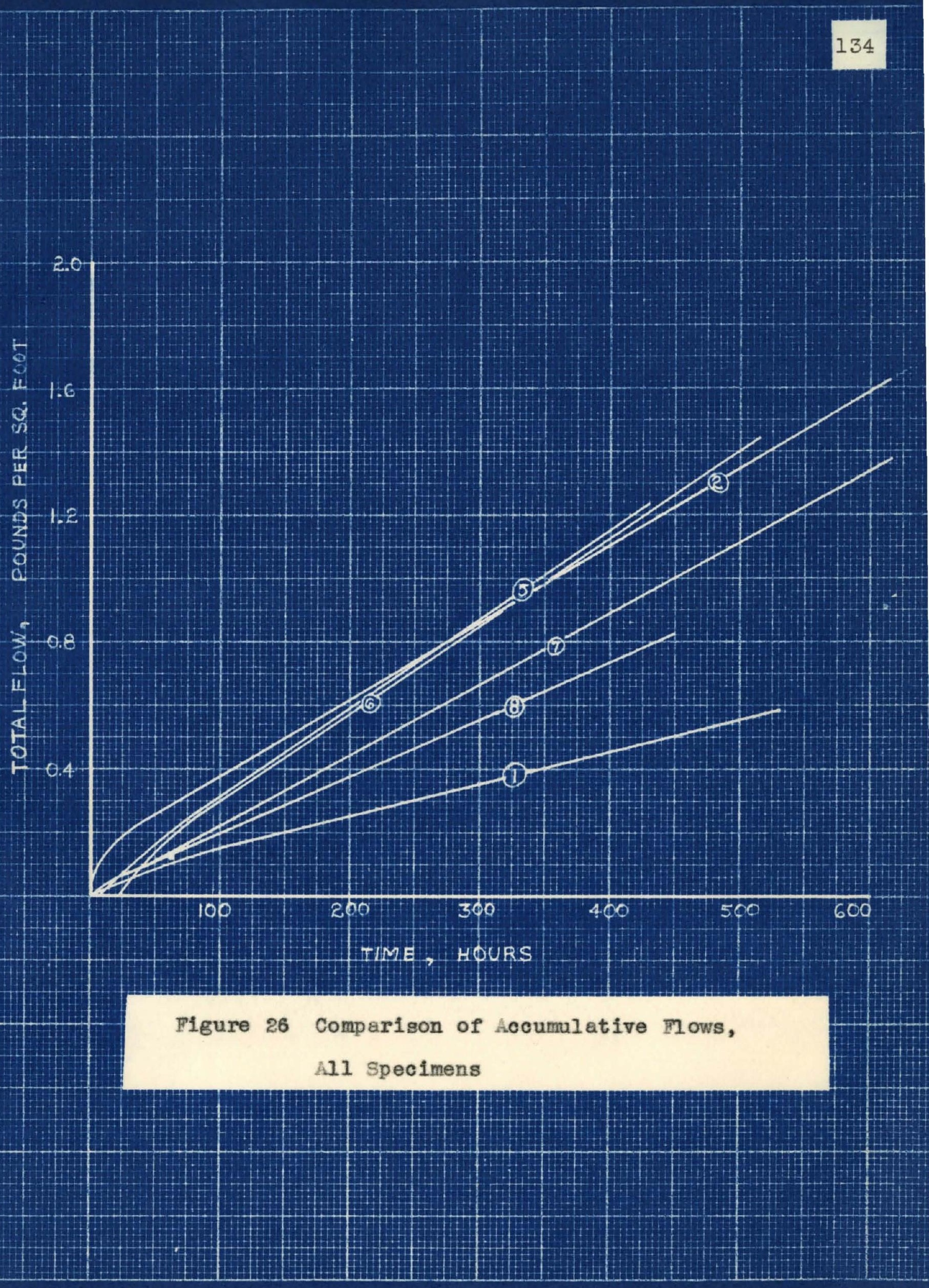




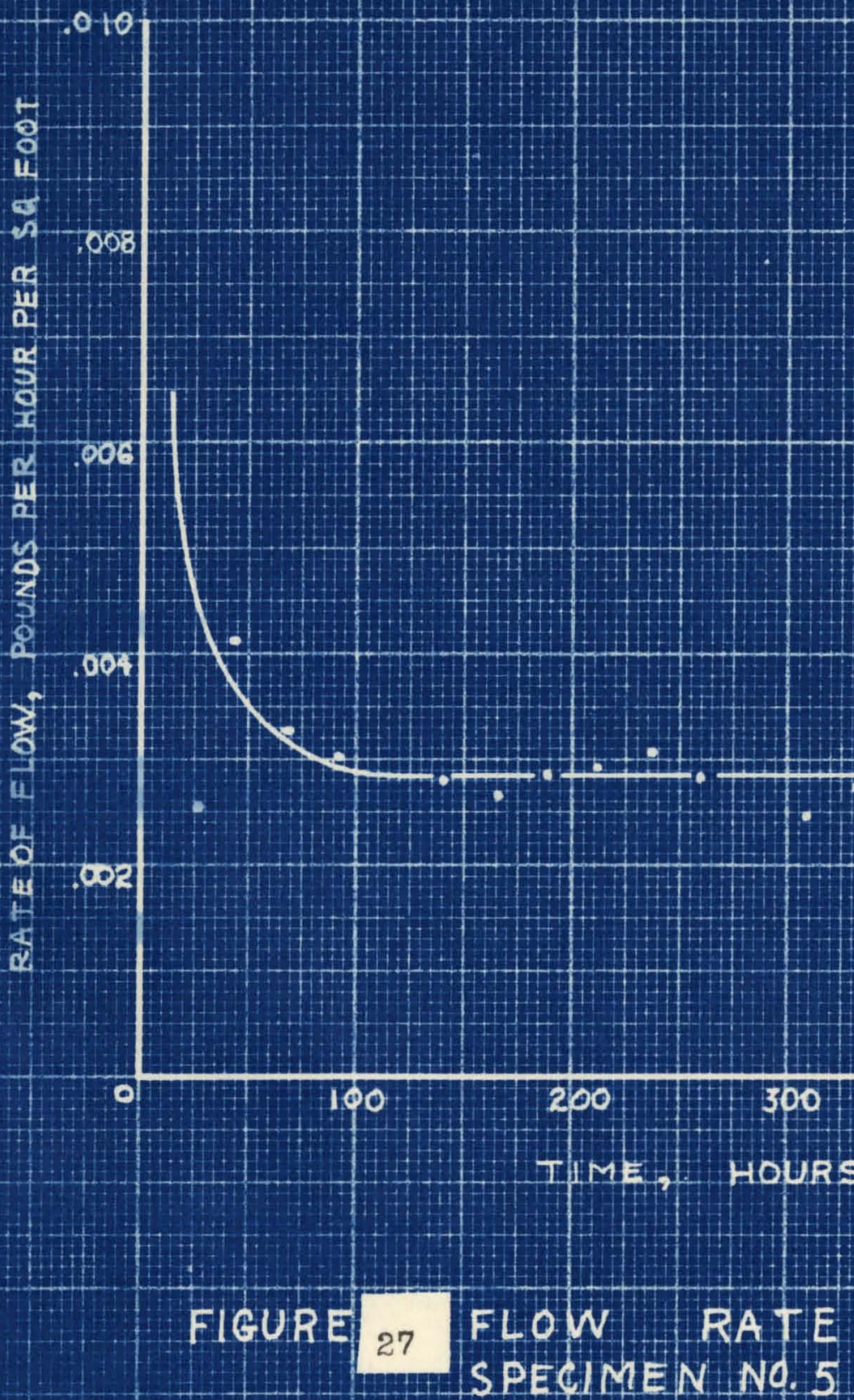




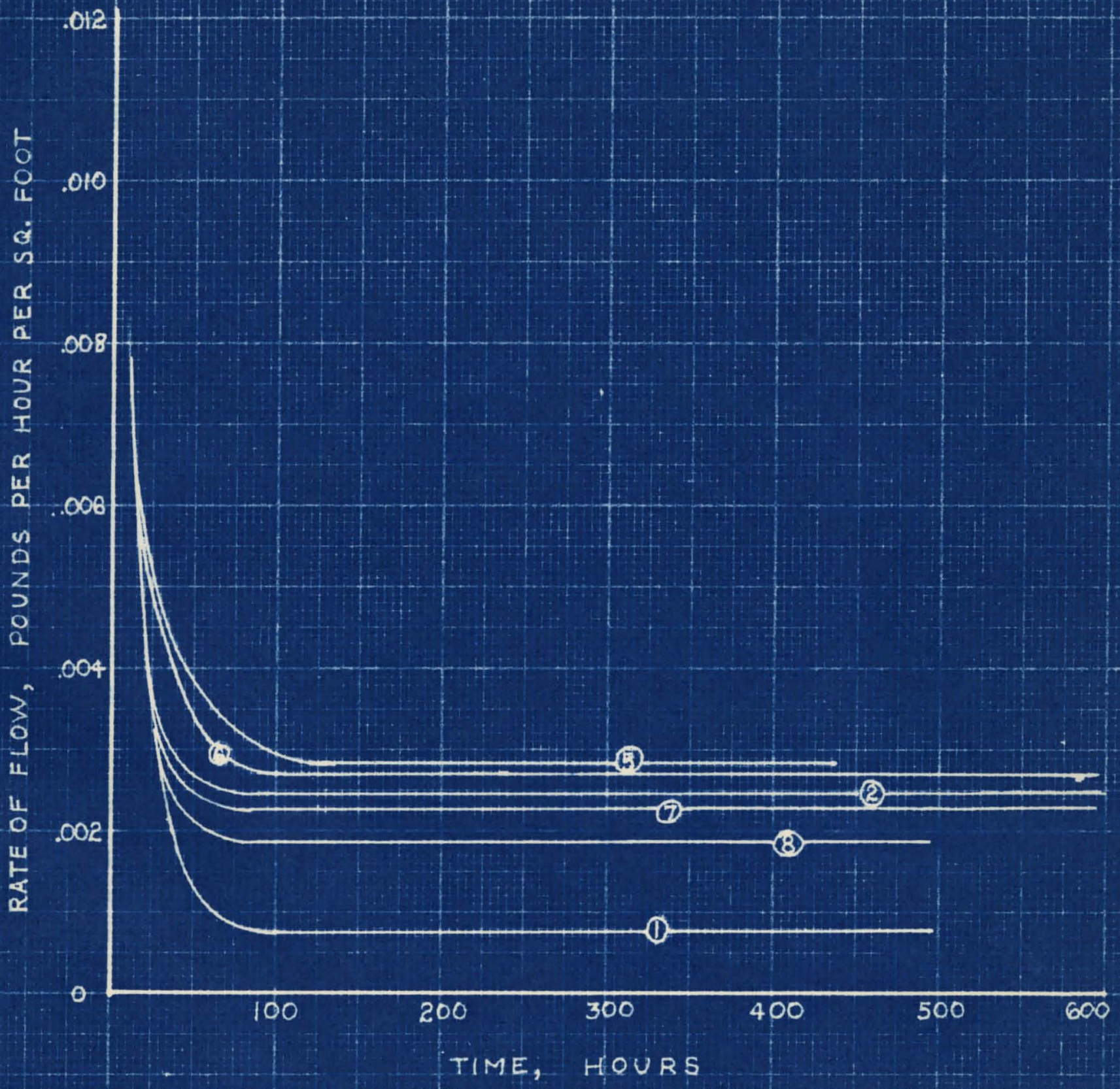

Flgure 28 Comparison of Rates of Flow, All Specimens 
TABLE XIV. IIQUID DIFHSION THROUOH LAMINATED VBNEERS

\begin{tabular}{|c|c|c|c|}
\hline $\begin{array}{l}\text { Speoimen } \\
\text { Iumber }\end{array}$ & $\begin{array}{l}\text { Pressure, } \\
\text { Peet of water }\end{array}$ & $\begin{array}{ll}\text { Constant Mow } & \text { Fow } \\
\text { Porlod, Hours } & \text { Ibs. }\end{array}$ & $\begin{array}{l}\text { Rate } \\
(\mathrm{sg} f t)(\mathrm{hr})\end{array}$ \\
\hline $\operatorname{Run}^{1}\{1$ & 3 & Indet. & .00000 \\
\hline 2 & 3 & Indot. & .00035 \\
\hline 3 & 13 & 300 & .00078 \\
\hline 8 & 13 & 550 & .00244 \\
\hline 3 & 13 & Grain Craoked & \\
\hline 4 & 13 & During Pre-soak & \\
\hline 5 & 13 & 350 & .00883 \\
\hline 6 & 13 & 425 & .00284 \\
\hline 7 & 13 & 800 & .00224 \\
\hline 8 & 13 & 400 & .00185 \\
\hline
\end{tabular}


changes. This factor should not affect the average flow rate deternined from the date because it would canoel a complete oycle of tomporature ohange. However, it would cause un apparent derlation of individual readings from the average. (b) The humidity ohanges in the surrounding atmosphere have not been taken into consideration. This effect is not considered of great importance in this invest1gation beoause it simulates actual conditions to be encountered in industrial use of the produot. It would, however, cause deviations of individual flow readings from the average. (c) A slight orror necessarily present in reading suoh small amounts of flow may have caused deviations, but this orror, too, is statistically unimportant as all 11quid additions were made in sequence in the same tube.

No relation has as yet been disoovered between the rates of diffusion of the various specimens and the curing conditions used in fabrication.

In a further attempt to correlate the results the physioal struoture of the oak reneer was considered. In the menufacture of rotary out veneer an oak $10 \mathrm{~g}$ is rotated agalngt a dootor blade whioh continually slloes away a sheet of veneer. In Its action this blade rolds the sheet of reneer baok away from the log, tendling to break the surface and generally roughen 1t. The degree to whioh this oraoking ooours is a funotion of the angle through whioh the blade bends the veneer from 1 ts original position, this 
in turn being determined by the original radius of curvature of that roneer. Fxtending radialy are medullary wood rays, whloh are necessar1ly more closely packed near the center of the $l 0 g$ than in the outer seotions. A oount of the number of these rays in a given width of the product should then be a measure of the original placement of the veneer in the $10 g$ and congequently the degree of oraoking caused by the outting blade.

The date are not sufficient for a oorrelation of results on this basis, but the method is argested as a possible meens of future attempts at deroloping a practioal relation. 
SUMMARY AND CONCLUSIONS 
Results of a study of the oharaoteristios of glue lines present in laninated $3 / 16$ lnoh rotary out, white ouk reneers have been presented. The investigation was confined to the physioal characteristies of flims of the resorolnol-formaldehyde resin Ponscoltte G-1124. The investigation took three forms. Flrst, the removal or all wood from the glue line structure by destructive digestion in ohromio aeld produoed an undisturbed glue flin whioh was studied by Visuel means. The glue film showed that great depth of penetrution had ocourred in open orevioes in the wood reneers. On the other hand some areas were very thin and a groat number of perforations were in evidence.

Seoondly, the depth and quantity of penetration of resin into the veneers wes determined by a progressive removal of small thloknesses of wood and glue from flveply laminated seotlons. A quantitative estimation of glue present in successivo layers of wood veneer led to a graphleal plot of glue penetration into the various veneers. Lastiy the relative resistance to the dirfusion of l1quid water of several sections of two-ply-veneer fabricated under controlled conditions was determined. Present data for thls study Indiate rery little influence of ouring oonditions and of the "loosenoss" or "tightness" of reneer used on the diffusional resistenoe of the finlabed produot. 
LITIRATURE CTTED 


\section{IITERATURE CITED}

(1) Brown, G. G., Trans. A. I. Ch. E. 32, 321 (1936)

(2) Brown, G. G., and Martin, H. Z., Truns. A. I. Ch. E. 35, 679 (i 941$)$

(3) Shorwood, T. K., and Jackson, R. M., Trans, A. I. Ch. E., 37, 959 (1941)

(4) Sore1, B., "Distillation et Reotifloation", Paris, Carrie and Naud (1899)

(5) O'Connell, F. E., Trans. A. I. Ch. Z., 42, 741 (1946)

(6) St1gger, B. K., M. Ch. B. Thesis, University of Loulsv111e (1947)

(7) Peavy, C. C., and Baker, I. H., Ind, and Eng. Chem., 29, 1056 (1937)

(8) Brown, G. G. and souders, M., Ind. and hang. Chen., $28,98(1934)$

(9) Brown, G. G. and Lookhart, F., Trans. A. I. Ch. S., 39,63 (1943)

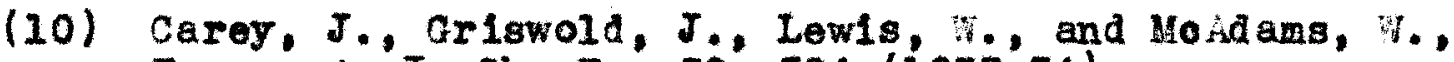
Trans. A. I. Ch. B., 30, 504 (1933-34)

(11) Good, A. J., Hutohlngon, M. H. and Rousseau, w. C., Ind. and Big. Chem., 34,1445 (ig42)

(12) Walter, J. F., and Sherwood, T. K., Ind, and Eng. Chem., 3\%, 493 (1941)

(13) Keyes, D. B. and Byman, L., Da18, of IIl. Bng. Exp. Sta. Bull. Ho. 37, 50 (1941)

(14) Drlokamer, H. O. and Brad ford, J. R., Trans. A. I. Ch. E., 39, 318 (1943)

(15) Gerster, J. A., Koffolt, J. H, and vilhrow, J. R., Trans. A. I. Ch. E., 39, 37 (1943)

(16) Ch1lton, T. H., and Colburn, A. P., Ind. and Bng. Chem. 26, 1183 (1934)

(17) Von Karman, Th., Trans. A. S. M. B., 61, 705 (1939) 


\section{IITERATURES CITED - ContInued.}

(18) Hummel, H. H., M. Ch. B. Thesis, OnIversity or Loulsv1110 (1939)

(19) McCabe, W. I., and Thiele, B. W., Ind. and Bng, Chom. 17, 605 (1925)

(20) Roblnson, C. S., and Q11111and, B. R., page 93 , Elements of Fractional Distillation, Seoond Edition, Mooraw Hill, New York (1943)

(21) Carlson, H. C., and Colburn, A. P., Ind. and Ing. Chem. $34,581-9(1848)$

(22) Lew1s, W. K., and Kay, $\mathrm{T}, \mathrm{C}, 011$ and Gas Journal, Maroh 29, 1934

(23) Davies, James A., Ind, and Jng. Chem., 39, 774 (1947)

(24) W111lams, G. C., Slaok, Glaneoakes, Pope, Groen, and Kayser, Chem. Rngr. Proj. 1946-47, Untrersity of Loulgitile

(25) Peavy, C. C. and Baker, I. M., Ind, and Eng, Chom. $29,1056(1937)$

(26) L1twin, H., 011 and Gas J., 45, No, 46, 237 (1947)

(27) Geddos, R. I., Trans. A. I. Ch. B., 48, 79 (1946)

(28) KIrschbaum, Emil, "Dostillier und Rektiflzlerteoknik", page 220, Berlin (1940)

(29) K1rsohbaum, Fat1, Forsoh, Geblete Ingenleuw, B5, 245-54 (2834)

(30) Lew1s, 等. K. Jr., Ind. and Eng. Chem. 28, 399 (1936)

(31) Langdon, W. M., and Keyes, D. B., Ind. and Ing. Chem. 35, $464(1943)$

(32) O'Connell, H. B., Unpubllshed Deta of the Bthyl Corg.

(33) Colburn, A. P., Ind and gng. Chem. 28, 526 (1936)

(34) Byman, L. and Keyes, D. B., Chem. and Mot. Engr. 48,85 (May, 1841)

(35) O'Brien, M. P., and Gosline, J. E., Ind. and Eng. Chom., 27, 1436 (2935) 
IITERATURE OITED - Continued.

(36) Johnstone, H. $F_{.}$and P1Eford, R. I., Trans. A. I. Ch. E., 38, 25 (1942)

(37) Furnas, C. C., and Taylor, M. I., Trans, A. I. Ch. B., $36,135(i 940)$

(38) Griswold, J., and stewart, P. B., Ind, and Bng. Chem., $39,753(1947)$

(30) Othmer, D. F., Chem, and Mot. Engr. 49, 84 (May, 1942)

(40) Sherwood, T. K., "Absorption and Extraction", page 2630, MoGraw H111, Hirst Edition, Now York, 1937

(41) Peok, R. E., and vagner, E. F., Trans. A. I. Ch. E., 41, $737(1945)$

(42) Von Kaman, T. H., Trans. A. S. M. E. 61, 705 (1939)

(43) Gllllland, E. R., and sherwood, T. K, Ind, and Eng. Chem. 26, 516 (1934)

(44) Chilton, T. H. and Colburn, A. P., Ind, and Eng. Chem. 27, 255 (1835)

(45) Surowlec, A. J., and turnas, C. C., Trans. A. I. Ch. E. 38, 62 (1942)

(46) Colburn, A. P., Trans. A. I. Ch. B., 35, 211 (1939)

(47) W1se, Lou1s E., mood Chemistry", Page 86l, First Isd1tion, ReInhold Publishing Co., Now York, 1944

(48) Milet1, otto J., M. Ch. I. Thesis, University of Louferille

(49) Castloman, Relph, Meoh. Engr., 65, 737 (1943)

(50) Bl aok, A., Wooh. Bngnx., 67, 337 (May, 1945)

(51) Binsos, R. D., 01son, 范, Z., Black, J. M., and Ranoh, A. N., Forest Products Lab., Mimoograph RIs3I (1946)

(58) Wanguard, F. T., Forest Products Lab., Mimeograph $1530(1946)$

(53) Forest Products Lab., 1336-h (1947) 


\section{IITERATURE CITED - CONCIUded.}

(54) Phodes, Phll1p H., Modern Plast10s, 28, 160 (Doo. 1944)

(55) Brlokson, Harvey D., MInn. Bro. Sta, Teoh. Bull. $182,3-42$ (1937)

(56) Stam, A. J., Ind. and Eng. Chem. 31, 901 (1939)

(57) Demaroo, A., and Sm1th, E. A., Ind, and Eng. Chem. (Anal. di.) 38, 775, (1946)

(58) Farrow, C. A., Hamly, D. H., and Smith, B. A., Ind. and Ing. Chem. (Anal. ed.) 18, 307 (1946)

(59) Tleman, H. D., "Yood Tochnology", P1tman Publishing Corporation, Rew York, (1948)

(60) Stam, A. J., Ind, and Eng. Chem., 31, 1150 (1939) 
APPENDIX 
NOMENOLATURE

a Surface per unit volume, sq. ft./ou. ft.

$c_{p} \quad$ Molal heat oapacity of 11quid

D Columan alameter, foet

7 Foed rate, lb. mols/hr.

HTU Holght of trangfer unit, ft.

$K_{0}$ Overall mass transfer coeffiolent, based on gas f1lm

$\mathrm{K}_{\mathrm{L}} \quad$ Overall mass transfer coerriclent, besed on

11quid rilm

I Ilquid tlow in colunn, mols/hour

M Moan molooular welght

N Number of mols transferred

P Product rate, 1b. moles/hour

$T$ Absolute temperature, degrees Xelvin

$\checkmark \quad$ Vapor flow in oolumn 1b. mols/hour

W Waste, bottoms, 1b. mols/hour

$x$ Yol fraction of component in 11quia

7 Mol fraction of component in vapor

$T^{*}$ Mol eraction of oomponent in vapor at equilibrium

2 Viscosity, pounds por foot hour

K Mass transfer oofflolent, ind1ridusi

9 Paotor determining slope of line jolning feed

composition and operating ilne intersection in

Mocabe - Trielo oalculation of theoretical plates.

t Temperature, degrees Centigrade 
$\alpha$

Relat1re rolat111ty,

$$
\alpha=\frac{\bar{y}_{A} /\left(1-\bar{y}_{A}\right)}{x_{A} /\left(I-\bar{x}_{A}\right)}
$$

Feuedo molel viscosity, centipolses

$\lambda$

Molal latent heat of vaporization

$\rho$

Donsity, pounds per oublo foot

Subsorlpts

$\begin{array}{ll}\text { A More volatile oomponent } \\ \text { B Loss rolatile component } \\ \text { b } & \text { Bolling polnt } \\ \text { d } & \text { Distillate } \\ \text { p } & \text { Feed } \\ \text { w } & \text { Product } \\ & \text { Faste, bottoms }\end{array}$


GLOSSARY

Aotual Number of Plates

The number of plates in the seotion considered over whloh the data were of sufflolent preolsion to use in calouletions - not necessarily the number of plates between foed and product or botween foed and waste. The number of plates whloh produoed onrlohment from $X_{m}$ to $X_{n}$.

Average Colum Temperature

The average temperature of the 11quid on the plates being consldered.

L1 quid-vapor Rat1o

The ratio of mols of 11 quid desconding to the mols of vapor rising at any point in the column.

Overall Exfloleney

The rat1o of the number of theoretioal plates to the number of actual plates. Overall rectifler efflclenoy Inoludes only the seotion of the column abore the reed plate; overall stripper efflolency, the section below the feed plate, and orerall colum efficloney, the entire seotion Including the food plate.

Pauedo Molal Viscosity

A psuedo visoosity based on a direct oomposition relationship. 
Operating Rat10

The 11quid-vapor ratio in tower seotions.

Relative Volatility

The rat1o of the mol Iraotions of more rolatile

components in the rapor to the less volatile component in the vapor divided by the ratio of the more rolatile component in the 11quid to the lose voletile component in the IIquid.

Theoretioal Number of Plates

The number of plates necessary to produce a given separation when 1deal Interchange exists between the phases, calculated by the method of Mocabe and Thlele (26) or a modifloation thereor.

Vepor Velooity

The superficlal velooity of the vapor rising in the column, based on the dlameter $D$ of the column and expressed in foot per second.

Retlux Ratio

Holal ratio of reflux to distillate at top of column. 
Those oaloulations are for Run No. 85,

Pontane-toluene.

Vapor Velocity

$$
\text { Vap. Ve1. } \frac{W_{v}(359) T_{1}(4)}{(3600) M(273) T \pi D^{2}}
$$

where $W_{V}=$ Pounds vapor/hour

$T_{1}=$ Temperature of plate 1. deg. $K$.

$D$ = Mameter of column, feot

Vap. Vel. $=\frac{(23 \quad 18)(350)\left(36 \frac{273}{(3600)}(144)(4)\right.}{D^{2}}$

Vap. Vel $=0.12 \mathrm{ft} . / \mathrm{sec}$

Operating Ratio

$$
\begin{aligned}
& \frac{L}{\bar{V}}=\frac{\text { moles } 21 \text { quid reflux/unit time }}{\text { moles vapor/unit time }} \\
& \frac{L}{V}=\frac{(23) \mathrm{H}}{(23+18) \mathrm{W}} \\
& \frac{L}{\vec{V}}=0.56
\end{aligned}
$$

Material Balance

$$
\begin{aligned}
& \text { Material balance is on acetone fraction } \\
& \text { Balance }=\frac{100 \text { (output) }}{\text { (Input) }} \\
& \text { Acotone in feed }=\left(\pi / M_{p}\right) \text { (wt Aoetone) } \\
& =(110)(.163) \\
& =17.9 \text { pounds/hour } \\
& \text { Aoetone in product }=\left(P / M_{p}\right) \text { (wt s isetone) } \\
& =(18)(.992) \\
& \text { - } 17.8 \text { pounds/hour }
\end{aligned}
$$


Aootone in waste $=$ negligible

Balance

$$
=\frac{(100)(17.8)}{(17.8)}
$$$$
=95.5 \%
$$

slope or q 11ne, $\frac{a}{q-1}$

Speciflo heat of pentane $=37 \mathrm{og} / \mathrm{gm} \mathrm{mol}$

specleto heat of toluene $=40 \mathrm{cal} / \mathrm{gm} \mathrm{mol}$

Mean spoo1fic heat $=c_{p}=x_{f}(37)-\left(1-x_{p}\right)(40)$

$c_{p}=(.276)(37)-(.824)(40)$

$c_{p}=38.5$

Holal latent heat $=\lambda=7700 \mathrm{cal} . / \mathrm{sm} . \mathrm{mol}$

$q=\frac{\text { latent heat of foed at feed temperature }}{\text { latent heat of foed at boling post }}$

$q=\frac{7700+(82025)(38.5)}{7700}$

$q=1.278$

slope $=\frac{q}{q-1}=\frac{1.278}{0.278}=4.60$

Theoretical Plates

The number of theoretloal plates was oeloulated by the method of Mocabe - Thiele. The equilibria data were plotted (rigure 27) and the reotifler operating line druwn from $X_{p}$ at a slope of $I / V$. From the $X$ equal $Y$ line at $X_{f}$, the $q$ line was construoted with a slope of 4.60 to intersect the operating 11ne. From this intersection to $X_{w}$, the stripper operating line was arawn. By a stepwise caloulation from X19 to XI, the number of theoretioal plates was found to be 7.7 . 
Overall Erriciency

$$
\begin{aligned}
& E=\frac{(200) \text { theoretical plates required }}{\text { aotual plates used }} \\
& E=\frac{(100)(7.7)}{16} \\
& E=48.7 \%
\end{aligned}
$$

Stripper and rectifler efrlolenoles were calcula-

ted In the same manner, using the approprlate end values for $X$.

Relative Volatility and Visoosity

$$
\text { Using the averege composition in the column } \alpha
$$

18 determined from a plot of Ts. oomposition.

$$
\begin{aligned}
& \alpha=8.75 \\
& \mu=0.31 \\
& \mu \alpha=2.71
\end{aligned}
$$



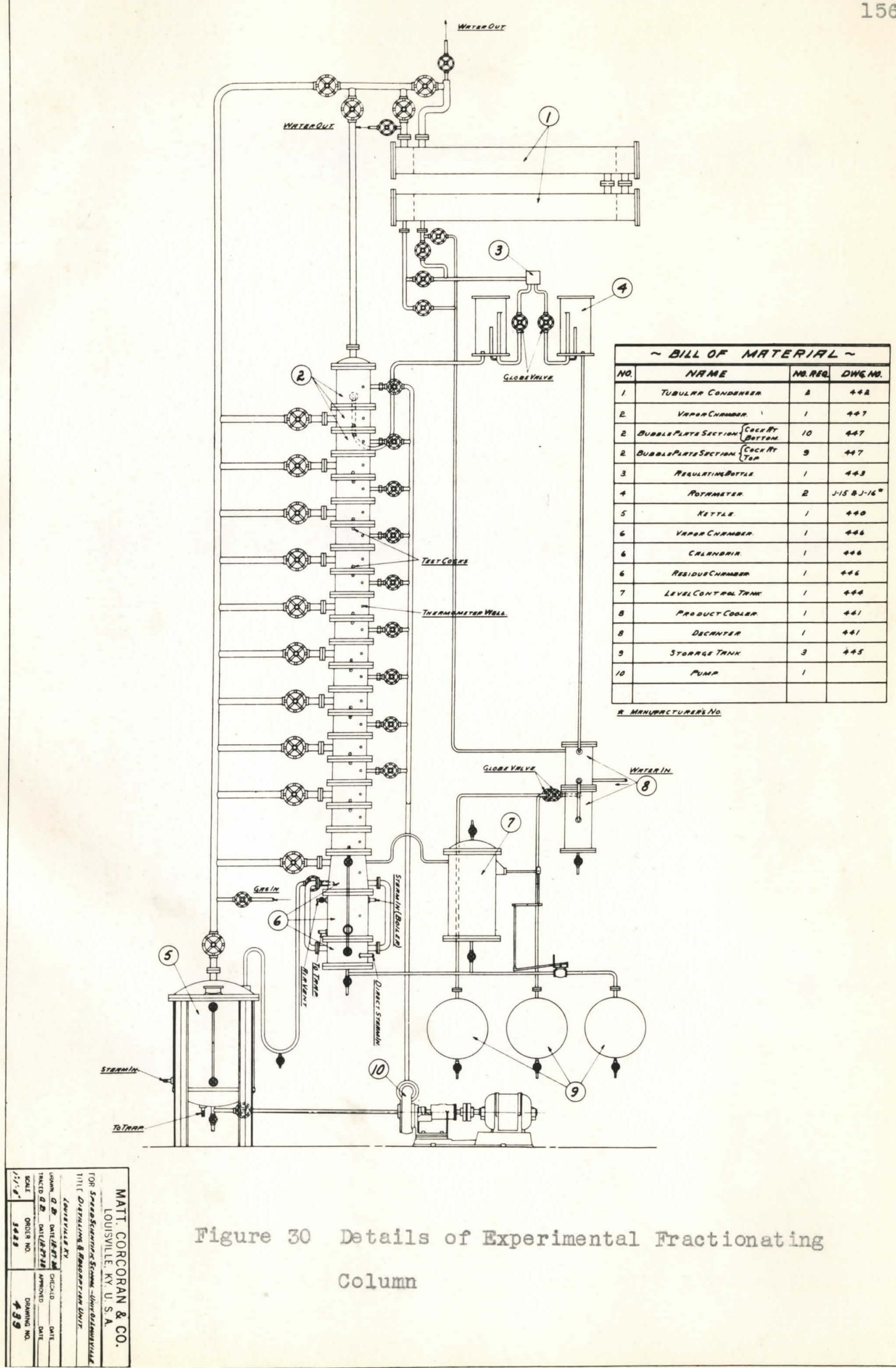

Figure 30 Details of Experimental Fractionating Column 

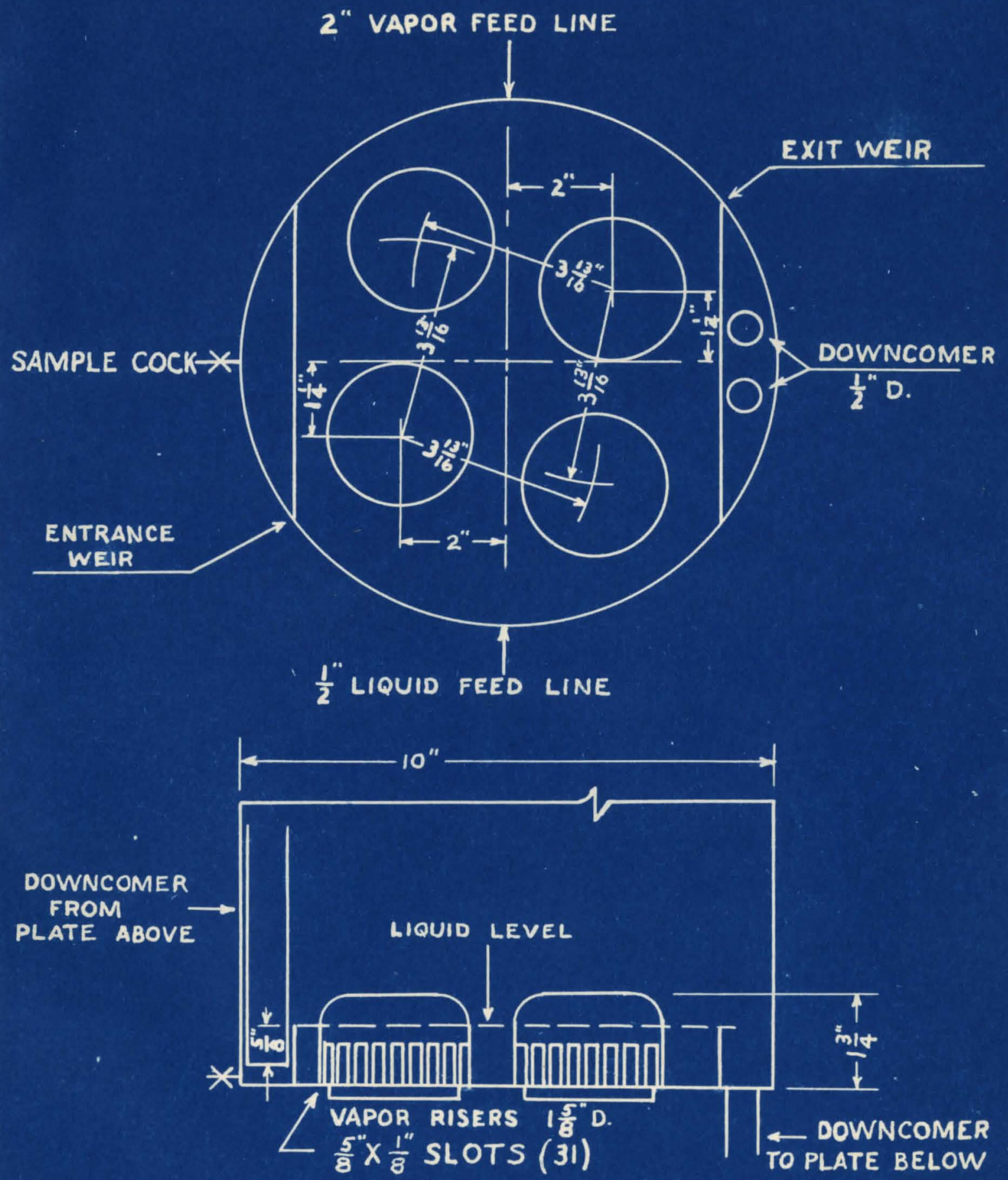

FIG. 31 DETAILS OF PLATE CONSTRUCTION 

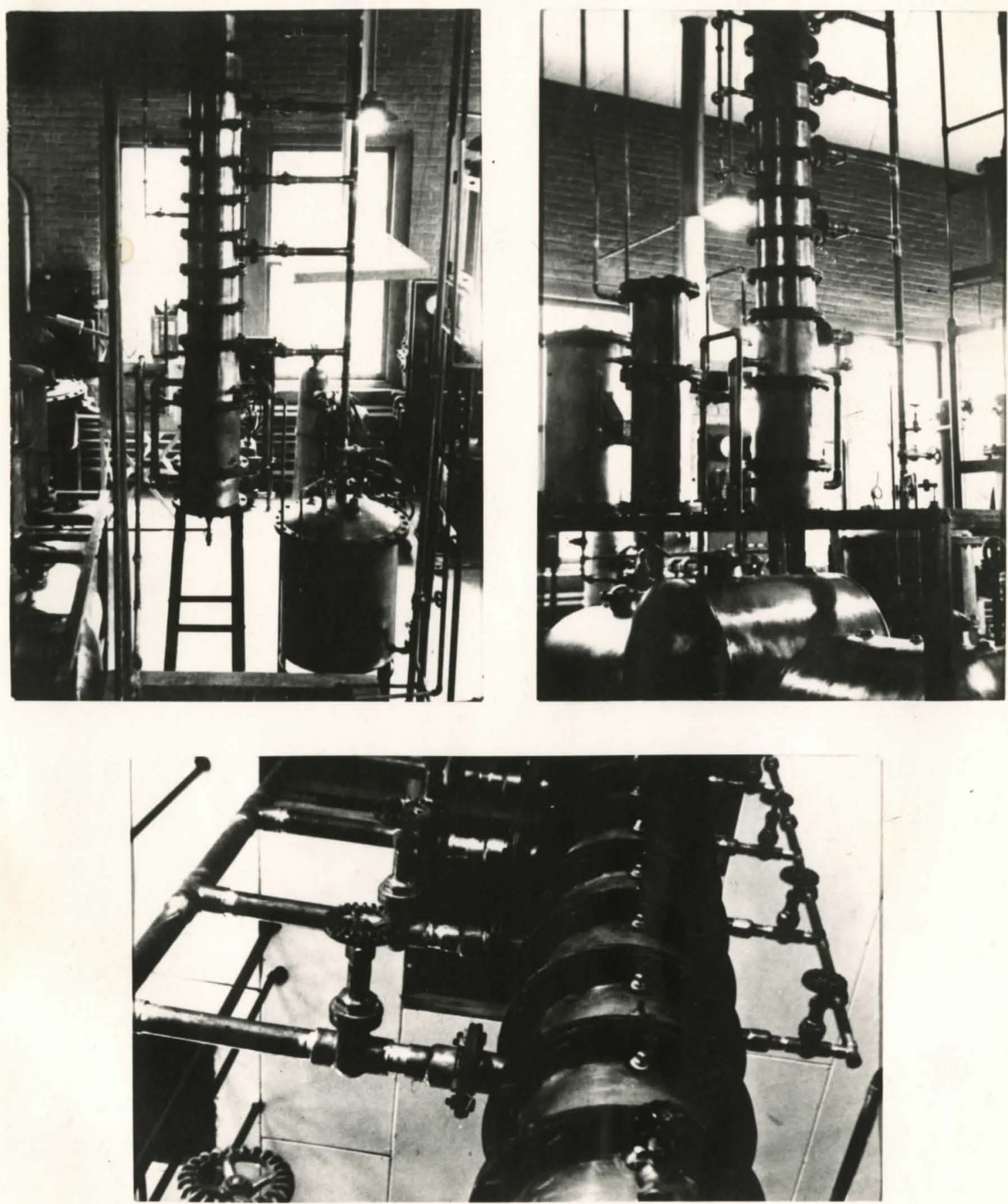

Figure 32 General Views of Fractionating Column 


\section{ACKNOWLEDGRLENT}

This research was made possible through followship grant from The UnIrersity of Loulsv111e Institute of Industrial Researoh as a portion of contraoted researoh with

The Ethyl Corporation and with

Camble Brothera. 
VITA

Jaok Hamlin Wichols, son of Claude 1 ., and Bonny (Journey) Mlohols, was born in Columbla, Tonneseed. July 24, 1922. After completing h1s primary education in Columbla he entered Iincoln county High sohool in Fayetteville, Tennessee, and graduated with honors in 1940. He recelved the degree of Bachelor of solence in snglneering and Cheristry at Tennessee Polyteohnio Institute in 1944. After two years service in the U.S.N.R. he returned to complete requirements for and to reoelve the B. Oh. B. from speed Solentiflo Sohool, University of Loulaville, in Maroh, 1947.

He was awarded an Inst1tute of Industrial Researoh fellowshlp at the Oniversity of Loulaville in 1947 and received the degree of Haster of Chemical Fngineering in December, 1947. 